Historic, archived document

Do not assume content reflects current scientific knowledge, policies, or practices. 
Selected

Tested

Seeds

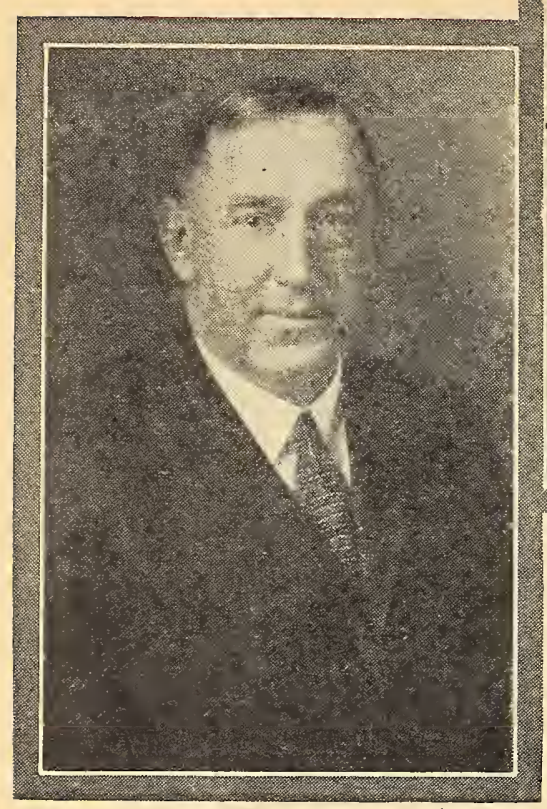

R. C. HEAD

Active Firm Member

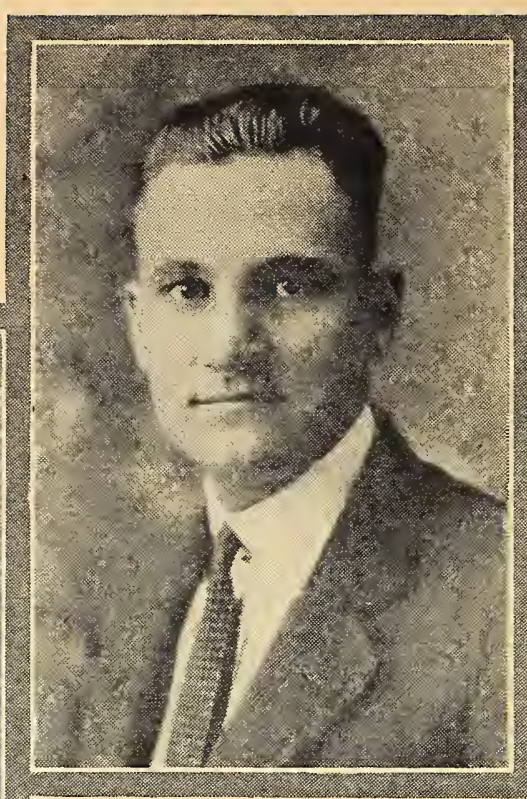

G. W. MACKEY General Manager

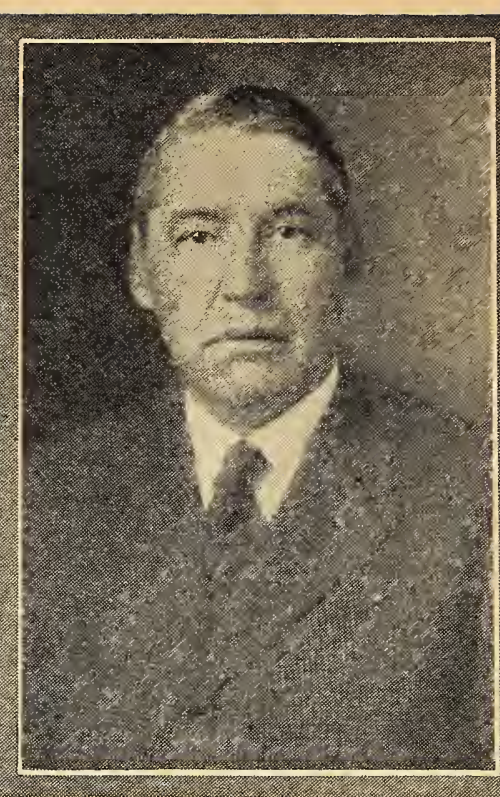

M. M. HEAD

Senior Firm Member

s马

\section{Something}

\section{About Ourselves}

Prompt Efficient Service

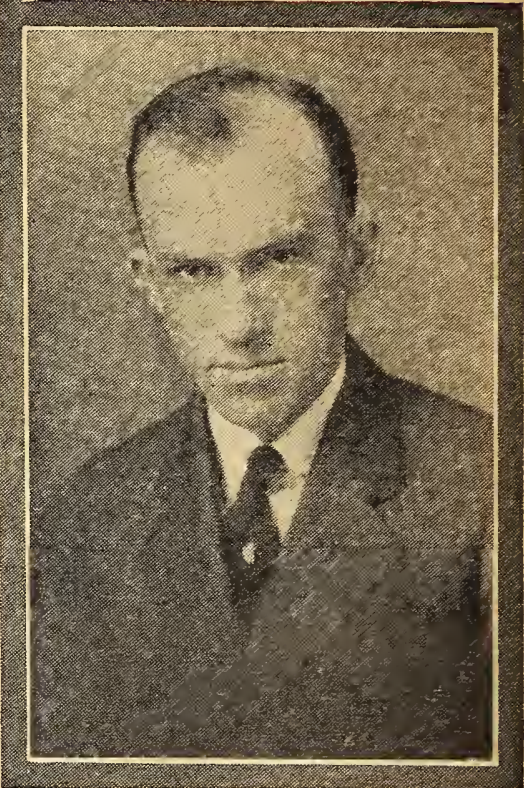

A. I. GORTON

Assistant Manager
$\mathrm{O}$ LD friends and customers may pass this by, but new ones will doubtless be interested in knowing who we are. Jefferson Seed Houses is an organization owned and controlled by Messrs. G. W. Mackey, M. M. Head and R. C. Head, all of Jefferson. The foundation for this organization was laid in 1884, just 40 years ago, with the establishing of the Ratekin Seed House at Shenandoah, Iowa. The organization today embodies the parent company (Ratekin Seed House) and the whole or parts of three other smaller concerns, namely, Jefferson-Ratekin Seed Co., Jefferson Seed Co. and Zeller Seed Co., hence the name, Jefferson Seed Houses.

Some idea of the extent and size of our operations can be had by picturing in your mind's eye the plants shown on the front cover and the 2,200 acres of land which we own and operate here in Greene county, each building and farm adequately equipped, and all backed by a perfected organization. Naturally, it takes a large volume of business to justify an organization of this kind. We have the volume; suffice it to say here, that more than 2,000 dealers are handling Jefferson Seeds, and more than 25,000 planters, not in touch with our dealers, send us their orders direct.

Mr. G. W. Mackey is our General Manager. Mr. Mackey is an experienced, well versed seedsman and a capable executive. His training started as office boy for the parent company and he has worked himself up through all departments to the head of the business. He is familiar with every detail of the seed business, is an acknowledged authority on farm crops, has a wide acquaintance among the seed trade, and is well known for his fair and square dealings. Mr. Mackey has played the dominant part in building our business to its present size and status. From the first he has exacted from himself and every member of the organization strict adherence to one policy, the policy stated in his letter on the next page.
Messrs. M. M. and R. C. Head, co-partners of Mr. Mackey, are active business men and farmers, both of highest standing and well known throughout the State. It was as farmers that they first became interested in the seed business, as each year they purchased several hundred dollars worth of seeds for their various farms. This experience, as purchasers of Jefferson Seeds, convinced them of the soundness of our ideals and policies and gave them the incitement to enter our organization with all the strength of their business experience and resources. They have helped give the business a stability that is second to none in the seed trade, and their practical knowledge of farming and seed growing has made it possible to offer many of the pedigreed strains listed in this book.

Mr. A. I. Gorton is Assistant Manager of our organization, being selected for this place on account of his wide and varied experience in the seed business. This experience includes four years as a department head for one of the largest mail order houses of the country and three years with a wholesale seed grower in the north. Mr. Gorton has spent considerable time as a traveler, buying, selling and inspecting crops, but the major part of his training has been in the handling of orders-from the time they are received until they have been filled, checked and shipped. He has two hobbies, Quality Vegetable Seeds (preferably northern grown) and Satisfactory Service to Customers.

The four men mentioned above are the leaders of our organization. The entire personnel is too large to introduce in a book of this kind. There are the department heads, traveling representatives, skilled workers on the farms and in the plants, the clerical force, and on down to the office boy. Each and every one of us cordially invite you to visit us. We shall take great pride and pleasure in showing you how dependable seeds are grown and handled and how well equipped we are to take the proper care of your seed business. 


\section{A Page About Our Qusiness Policies and Responcibility.}

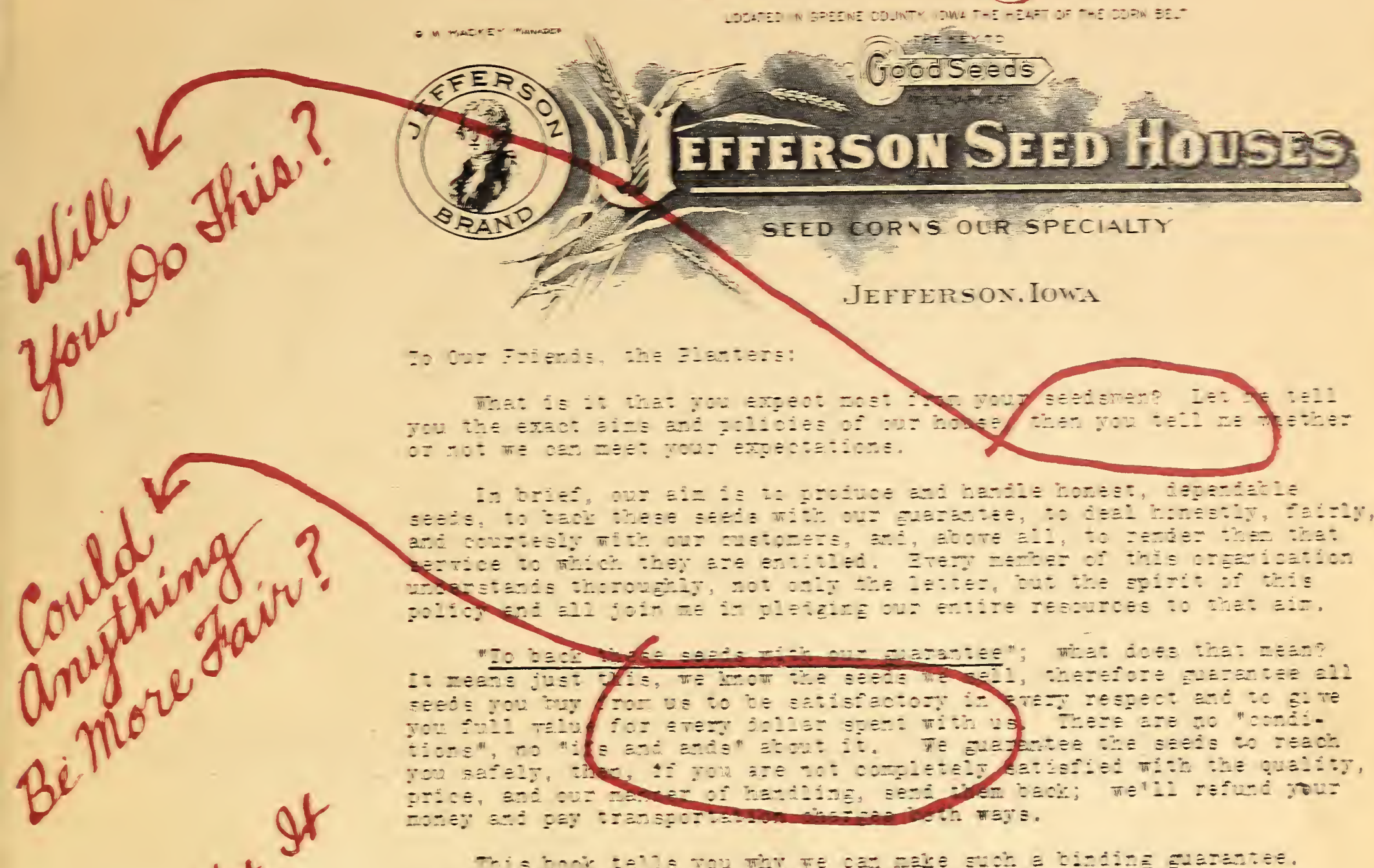

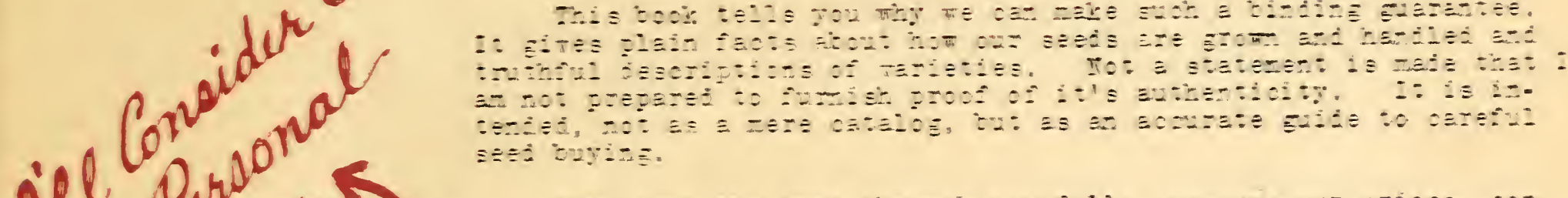
a

THEFirste National Tjavk

JEFFER SOX.IOWA.

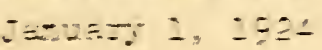

Z: whore $Z:$ y

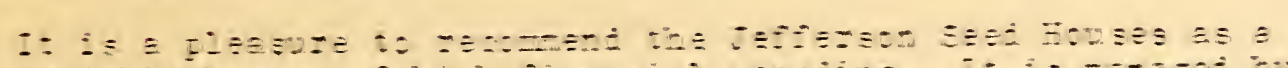

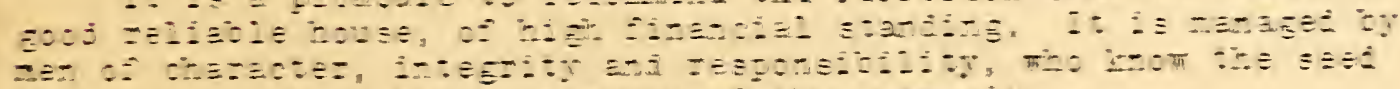

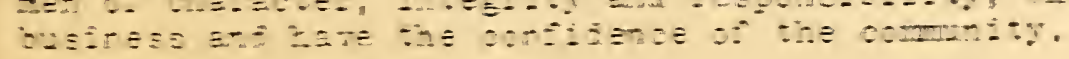

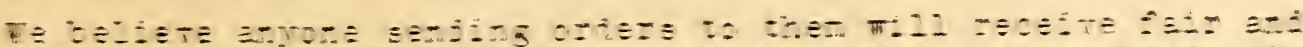

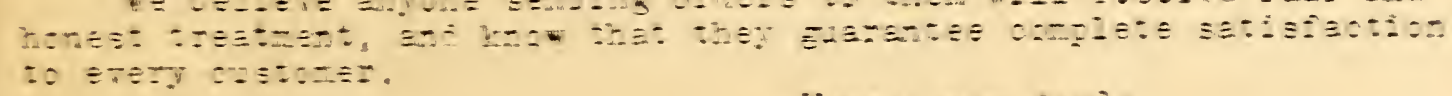

$Q=\square \div$

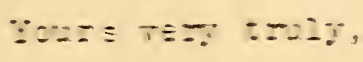

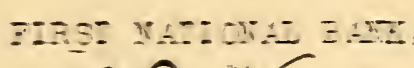

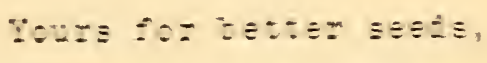
Silumadey

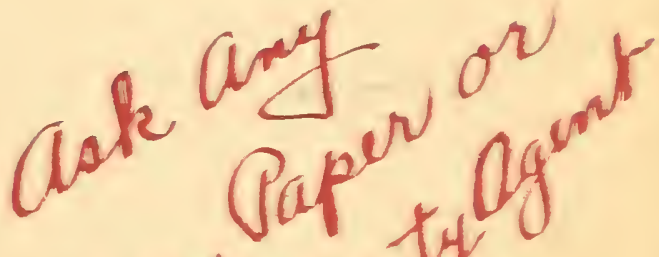
Tran count

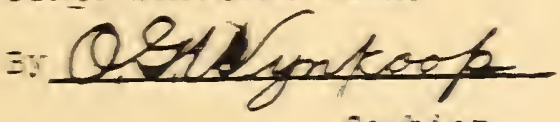




\section{JEFFERSON SEED CORN}

In telling you of our Seed Corn Department, it's hard to do it Justice without having you think that we are exaggerating. But when you know that Jefferson Seed Houses are the largest growers and handlers of Seed Corn in the entire world, you'll realize that this indicates a great demand for Jefferson Seed Corn and an elaborate system of growing and handling. The "largest Seed Corn Growers in the world" is a pretty big statement to make but we're just that. We have 2,200 acres of our own, most of it in corn, and 2,000 to 4,000 acres additional under contract, all planted with our stock seed, and cultivated and harvested under our supervision. This immense acreage is located in the best corn County of the best Corn State in these United States, or the entire world for that matter, Greene County, Iowa.

\section{A Department Headed by an Expert}

This great volume of Seed Corn handled makes a business by itself. It requires the entire "Seed Corn Plant" pictured on the front cover and a force of 40 to 50 men, all experienced in the handling of Seed Corn, to take care of our Seed Corn business. At the head of this department is Mr. C. E. (Dad) Mackey, a pioneer Seed Corn man "Dad" Mackey has devoted nearly 45 years to the growing, breeding and selecting of Seed Corn. Hundreds of farmers who have met him personally, and consulted with him on corn, will tell you that he is the peer of any man outside the agricultural colleges, when it comes to giving advice about the growing of corn and the selecting of varieties for different localities. In buying Jefferson Seed Corn, you get the benefit of this knowledge and experience for every bushel of Seed Corn must have his personal $O$. K. before it leaves our house. And, in his own words, "Every

\section{How Our Seed is Handled}

It would take an entire book to tell you of the breeding methods used in securing the planting stocks from which Jefferson Seed Corn is produced. No effort or expense is spared to have the best. We don't go in for fancy show stocks, but for utility types; that pure, disease free, early maturing, and high yielding corn that every farmer needs to make a showing on his bank book.
Our growers are all experts in their chosen line. They know how to plant aud care for the crop. As soon as the corn is in tassel our field men go through the fields and de-tassel all diseased and barren stalks. Every corn grower knows the reason for this. The corn is then allowed to mature, remaining in the field as long as weather conditions will permit, in order to receive full benefit of Nature's process of drying, which is the best method ever devised for curing corn. When the time comes, though, to get the corn inside, everything else is made secondary to that end and there is no rest until the entire acreage is husked and in our houses.

In the house, the corn goes through a rigid selection, every ear being handsorted by men who have been trained in this work. It is then tipped and butted, shelled, cleaned, and thoroughly graded. All this by special built, efficient, and labor-saving machinery. The corn is then put through our $\$ 7,000$ direct heat drying system. This system is believed to be the most efficient of any that can be used in the drying of Seed Corn. By its use the moisture content can easily be reduced to the required $15 \%$ and the temperature is so controlled oy thermostatic regulation that there is no possible chance of impairing the germination. The result of all this selection and preparing is a finished product with a pedigree, fully dry and mature, all grains of uniform size (an absolute necessity for the proper working of your planter), free from tips, butts, and cracked grains, and seed which we guarantee to germinate tips, butts, and cracked grains, and seed which

\section{Increase Your Yield and Quality}

We want you to plant Jefferson Seed Corn this year. We want to prove to you that we can increase the yield and quality of your corn crop by furnishing you with pedigreed seed. Remember, in counting the cost of Seed Corn, one bushel of corn will plant 7 to 8 acres. The cost of our pure-bred varieties is but 50 to 60 cents per acre. Only one bushel per acre increased yield more than pays all the cost of the seed. The commonest mongrel scrub corn costs you something. The corn we grow and sell you is not only selected seed, but is pure-bred, has been carefully handled, dried, and cured, as Seed Corn should be, and will grow and give you 10 to 40 bushels per acre increased yield over ordinary varieties. This is no idle boast. Our seed is doing this for thousands of wide-awake, up-to-date farmers.

\section{Positive Proof of Its Superiority}

Read what the Jefferson (Iowa) Bee of March 8, 1922, has to say about Jefferson Seed Corn.

\section{Shipped Forty Cars of Iow a Seed Corn}

Jefferson Seed House Furnishes U. S. Government 60,500 Bushels Greene County Seed Corn for Planting in Russia

"What is thought to be the largest single order for Seed Corn ever handled by one company. has just been shipped by the Jefferson Seed Houses of this city. This company have this week completed shipments totaling 60,565 bushels of Seed Corn which is being shipped to Russia for Russian Relief.

This Seed Corn was purchased by The United States Grain Corporation, under direction of the United States Government. Mr. G. W. Mackey, manager of the Jefferson Seed Houses, was Government Crop Reporter for Greene County and this part of the State during the World War, and it is presumed that the valuable service he gave the Department at that time, together with the national reputation the officials in charge in connection with his firm being favored with this large order.

As soon as the contracts were completed, the company called in a large amount of the corn grown under contract for them by Greene County farmers and shipments started at once. It might be well to state here that this company, besides operating over
2,000 acres of their own farms, place contracts and furnish the seed for growing purposes with some of the best farmers in Greene County. The writer had the pleasure of viewing a the company had control of over 5,000 acres of corn

Throughout the preparation of this order for shipment, the company's wonderful machine is nothing in constant operation. The working of this built to the company's order for extracting all excessive moisture from Seed Corn, as well as polishing the seed without affecting or damaging the germination, officials and has saved the Jefferson Seed Houses, as well as their customers,
thousands of dollars, especially on Southern shipments where corn containing excessive moisture deteriorates very rapidly.

It required 40 large freight cars to liaul the seed to Baltimore, the coast
shipping point, each car holding 600 bags, or 1,500 bushels to the car. The large electric loading truck was used in carrying the bags from the warehouse floors into the cars and anyone who missed seeing this machine in action, and

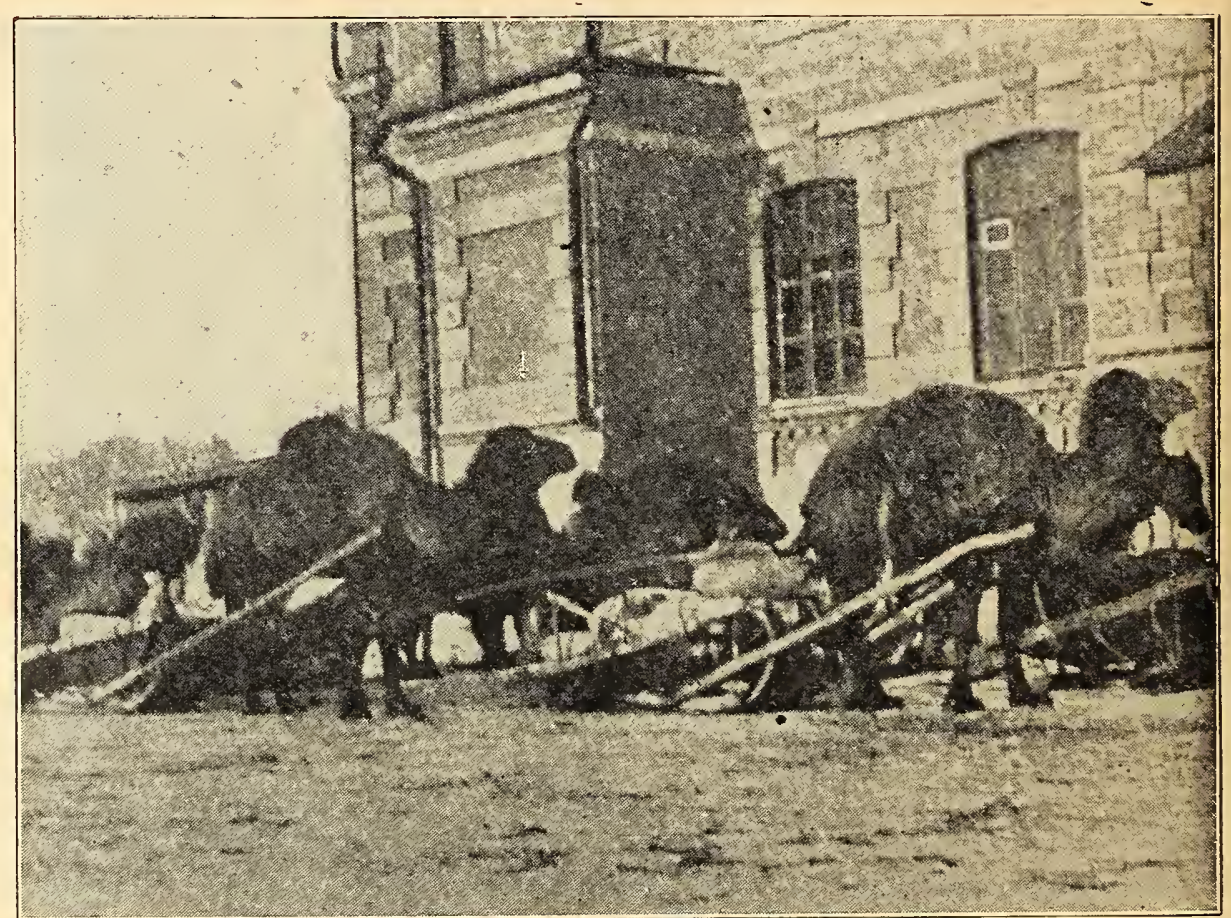

Camel sleds loaded with Jefierson Seed Corn at Orenburg, Russia From Saturday Evening Post, Copyright 1922 by the Curtis Publishing Co.

the wonderful system by which the fifty men on the company's pay roll handled this large order, missed a great sight. No one who missed this sight can have the slightest conception of the amount of work and responsibility connected in handling an order of this magnitude.

The Bee wishes to congratulate the Jefferson Seed Houses upon securing the large order, and all those connected with handling it. We hope they may secure many more large orders. We know that they are a hard working, constandard of the Seed Corn business above the level from which unscrupulous dealers or elevator "Seed Corn" concerns have endeavored to lower it. A Seed House of this kind, doing business all over the United States, Canada, and other foreign countries, advertises Jefferson and Greene County as no other business can possibly do. The securing of this large order shows that the management is awake and that the company is favorably known." 


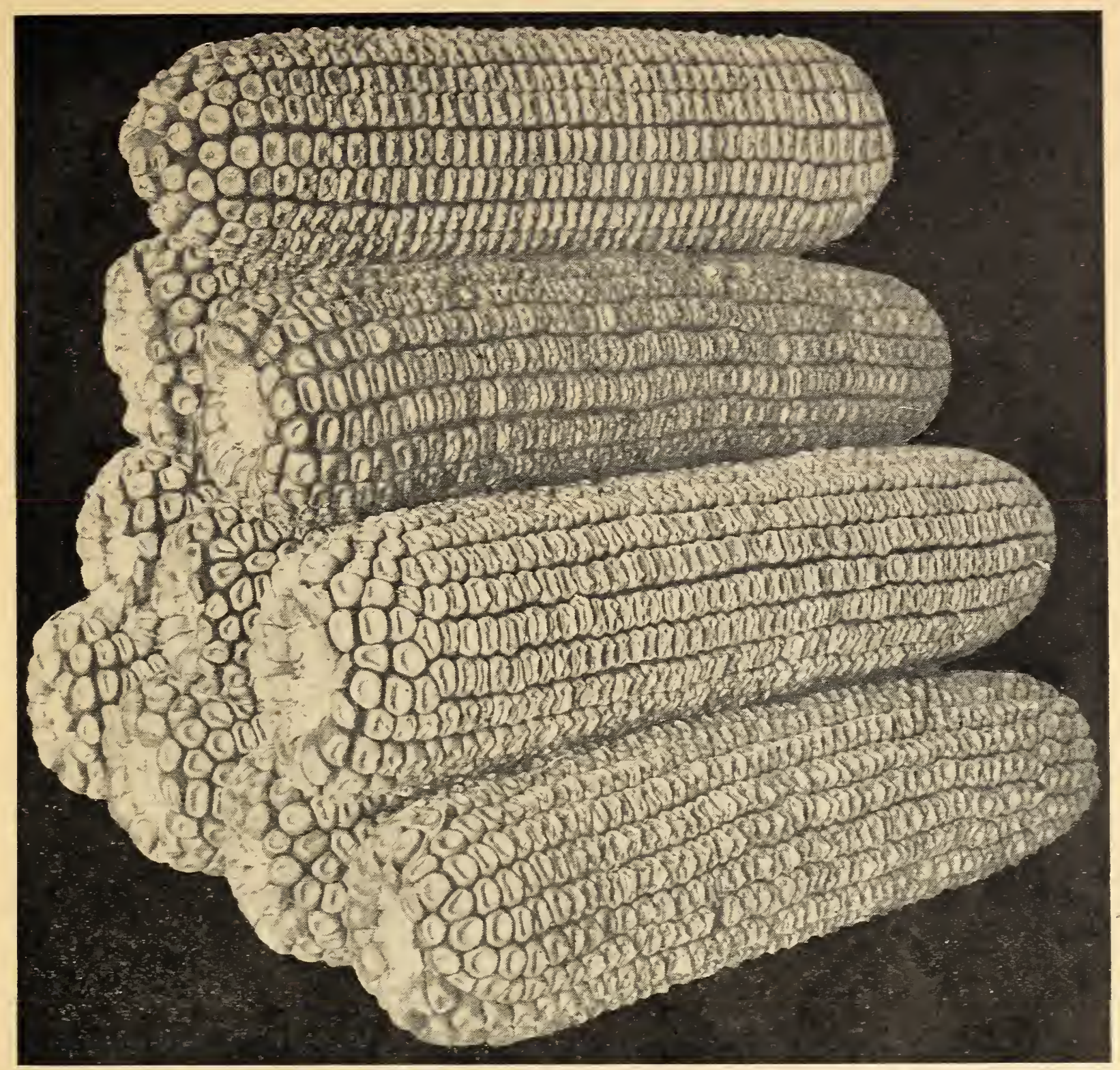

\section{Diamond Joe Big Early White}

The Earliest Maturing Big Eared, White Corn Grown.

"Until you've grown Diamond Joe you don't know what good corn is," says Everett Orme, a prominent farmer of Hopkins, Mo. We wont express ourselves quite so strong as Mr. Orme, at least not in print, but we do know that there is none better-none like it, and that but few, if any, equal it. in 1905 , since which time it has been thoroughly tried and tested throughout every corn growing state in the Union. Everywhere, north, east, south, and west, it has won great praise and commendation from corn growing farmers. This, by reason of its uniform increased vields over other varieties, its drouth resisting ability, and its adaptability to the seasons, soil, and climate of about every state where corn is successfully grown.

Diamond Joe is especially adapted to states where the corn crop is often and in some following seasons since, in the great drouth-stricken districts of Nebraska, Kansas, Missouri, Oklahoma, Texas and other Southern States, where we sold thousands of bushels of this variety, it proved to withstand and resist drouth and hot winds to a much greater extent than any other variety. and other varieties made scarcely nothing, and at best but 5, 10, and 15 bushels per acre. This is accounted for in part by reason of its deep fiberous root system penetrating the soil almost like Cane or Kaffir Corn; also by reason of its early maturity, thus making itself in the season while the moisture and In short, our Diamond Joe has made good everywhere and has an unparalled record by test of $1331 / 2$ bushels per acre under ordinary culture, and a record in hundreds of instances of over 100 bushels per acre. this The accompanying illustration is a true picture, from a photograph of this corn some ping its general type and character. From the name we gave grown variety, but it is not. It is, however, a large-eared corn, running somewhat larger in size than Iowa Silver Mine. Every stalk produces one and two large, strong and robust, growing to a height of 8 to 12 feet, dependent upon land (upland or bottom land), has a very heavy and extensiv giving it its vitality to resist drought and hot weather. Medium ears run from $8,10,11$ and some 12 inches and over long, usually about 10 inches, 16
to 20 rows, deep kernels solidly set on cob of medium size. In short, this corn was bred with an eye to heavy yields, early maturity and all around genera crop purposes, not for show purposes. There is no variety that will do better or even equal it on old, poor or hill ground, and at the same time there is no variety It is the embodiment of all the good qualities contained in all the best varieties; it's the sure thing. Our seed stock of this corn is exceptionally fine this year and absolutely pure; we hope to be able to fill every order that comes to us, large or small. If you are looking for the corn that will make you the most bushels and the most money, stop right now and order enough to plant your land er. This is the corn that will do it. Plant Diamond Joe on good Prices, postpaid: Ear, 50c; lb., $40 \mathrm{c} ; 7$ lbs. (enough to plant 1 acre), \$2.25.

Jefferson Seed Houses,

Jefferson, Iowa. Just a few words in regard to that Diamond Joe Seed Corn I ordered from Just a few words in regard to that Diamond Joe Seed Corn help telling you about it. I planted 25 acres and it sure beats any corn I have ever raised. It is making 70 to 75 bushels per acre and is so much earlier than I have been offered a good substantial price for it by a seed dealer. 1. A. RILEY, Dow City, Iowa

Jefferson Seed Houses,

Jefferson, Iowa.

Dear Sirs: I am writing you concerning the Diamond Joe Seed Corn I I want to assure you that you need never to be afraid to recommend it for this part of Alabama, as it has just done fine for me and also for a friend two and three large ears to a stalk this year when all or nearly all other varieties have failed. 


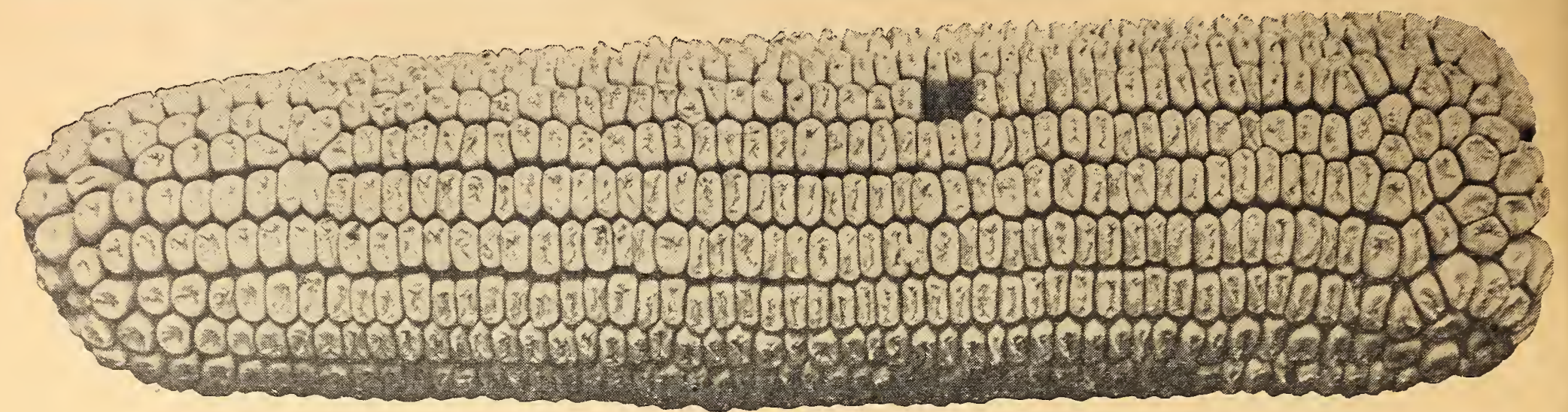

Greene County Prize Winner

\section{Greene County Prize Winner}

Positively the Best, Early All Purpose Yellow Corn.

"Dad" Mackey, our Seed Corn expert, is very emphatic in stating his preference for this great and grand variety of corn over all other yellow varieties. And we truly believe that every farmer who has.grown Greene County Prize Winner holds the same opinion. Possessing the beauty of Reid's Yellow Dent, the depth of Iowa Gold Mine, and the early maturity of Pride of the North, it can be truthfully said that this corn has the combined virtues of all the College and has been thoroughly tried and tested throughout the corn belt. Everywhere pronounced the best all-around early yellow corn uniformly producing more grain and a larger tonnage of fodder than any other. This same report comes from growers on all kinds of soils and all latitudes where corn is grown, showing it to be adapted to a wide range of conditions. On our own farms, where more acreage is devoted to this than any other variety with the single exception of Diamond Joe, it yields from 62 to 100 bushels per acre every year.

The stalks run from 7 to 10 feet high, thick and heavy with a broad, succulent, leafy foliage, giving it great value as a fodder or ensilage corn. Ears from 8 to 11 inches long, 16 to 20 rows of deep, bright J ellow kernels, solidly set on a small cob; weighs out 2 to 4 bushels more per wagon load, thus proving its soundness and maturity. In short, the ideal corn for the general farmer, the stockman, or the dairyman.

We have an exceptionally fine seed stock to offer this year. Our crops of this variety all ripened early and were harvested and on the drying racks before the first freeze of the season. As this is written the corn is being hand-sorted for the second time, and we want to say that in all our experience we have never seen better seed. Our reputation and guarantee is back of every bushel we sell. It's an absor
order this corn.

Price, postpaid: Ear, 50c; lb., 40c; $7 \mathrm{lbs}$. (enough to plant 1 acre), $\$ 2.25$.

\section{Pride of Nishna Yellow Dent (100 Dats)}

More Than 50 Years of Pedigree Behind This Corn.

One of the very few varieties of field corn that has a history of more than fifty years of improvement behind it. It was the first corn planted by Mr. J. R. Ratekin, the founder of our parent company, after migrating from Illinois 57 years ago. Although at that time corn was "just corn " as it is yet in some localities, Mr. Ratekin was an enthusiastic and strong believer in pure-bred seed. He began at once to breed and select an improved variety, crossing and re-crossing different strains, finally developing this early maturing, big-eared type of corn known today all over the United States as Pride of Nishna. and dise have continued the careful breeding and selection thus started. Barren heavy heavy yielder. The stalks grow 8 to 12 feet high, strong and robust; very leafy, broad blades, and plenty of them. Roots, almost the equal of sorghum, in sizs resisting wind and storms, and standing up well. Ears solid, uniform rows of broad, deep kernels. Its rich golden yellow color makes a full crib of this corn a most beautiful sight to look at. Those wanting a high grade, early maturing, big-eared type of corn need look no farther. Our word for it, .

Price, postpaid: Ear, 40c; lb., 30c; 7 lbs. (enough to plant 1 acre), \$2.00.

See Current Price List for Quantity Prices of Seed Corn.

Sept. 1, 1923.

Gentlemen:
Your Greene Co. Prize Winner Corn is the corn for me. Year after year it gives me more feed, both grain and fodder, than any corn I can grow. As soon as your seed from this year's crop is ready send me prices on 10 bushels.

Yours truly,

RAY GILLESPIE

Clearmont, Mo.

\section{Mammoth Iowa Yellow Dent (100-110 DAYS)}

Famous for Its Uniform Large Ears and High Yielding Qualities.

A variety of great merit, originated by us and introduced in 1911 after six years of the closest and most critical observation, careful breeding, selecting and improving in every possible way. The accompanying illustration is from a photograph of a medium sized ear; they run from 9 to 12 inches long, are very symmetrical, each one containing 18 to 22 rows of broad, thick, kernels of more than average depth. Stalks with closely set blades and foliage grow from 8 to 12 feet high, and are supported by a remarkable root system, thus enabling this variety to resist heavy winds, drouth and scorching hot weather.

Mammoth Iowa Yellow Dent is beautiful with its rich golden yellow color and even size from butt to tip of ear. Its early, quick growth and maturity makes it a vers certain and sure cropper. We can fully recommend it to our customers everywhere and assure them that they will make no mistake in planting largely of it. Remember that we grow our Seed Corn and know what it is before we offer it for sale. Every bag is tested for germination and moisture content and we guarantee satisfaction.

Price, postpaid: Ear, 40c; lb., 30c; 7 lbs. (enough to plant 1 acre), $\$ 2.00$.

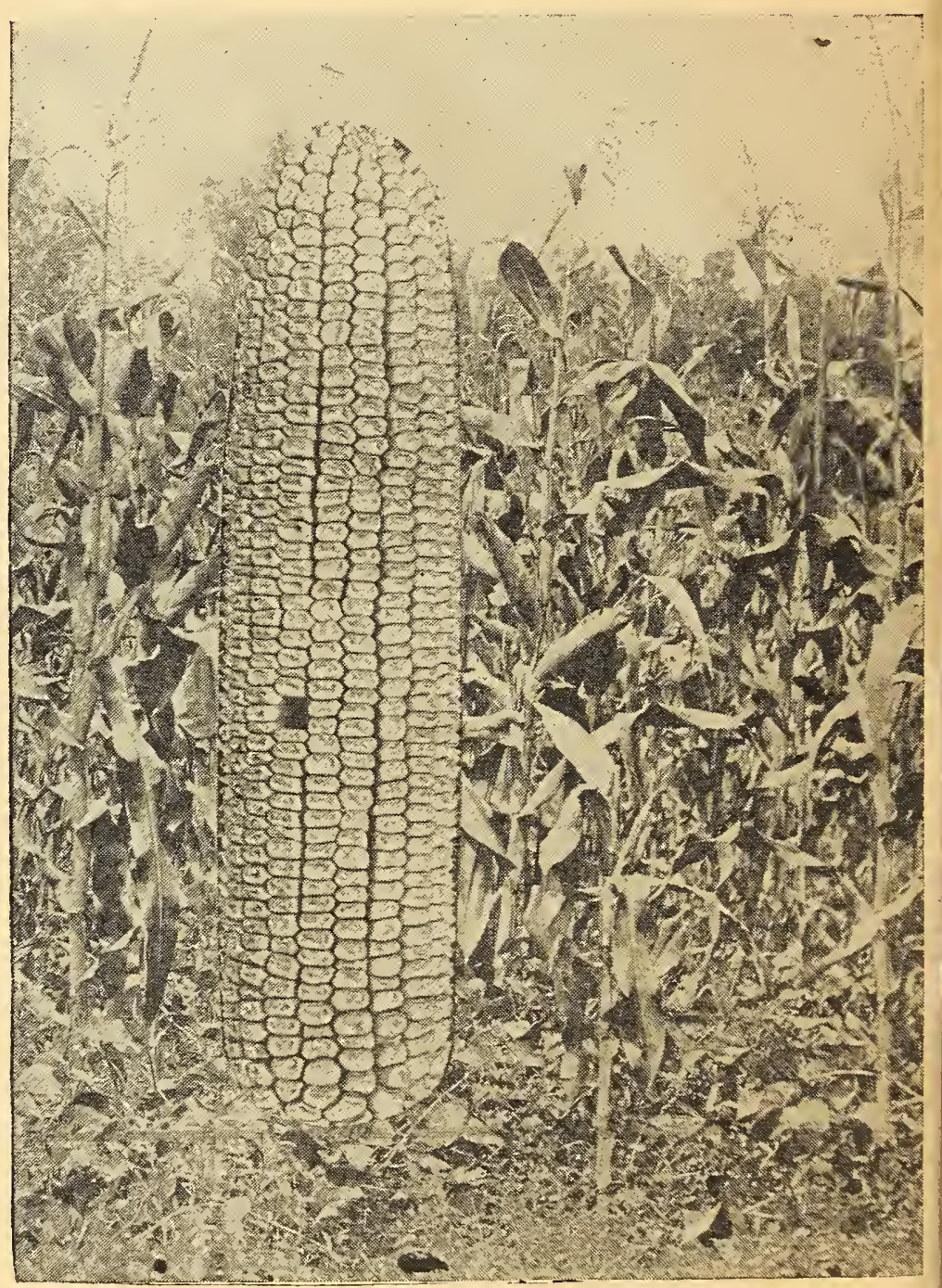




\section{Reid's Yellow Dent (110-120 DArs)}

If any Seed Corn can be truly called pedigreed, Reid's Yellow Dent is certainly entitled to be known as such as its history dates many years back. It has been bred up and selected with painstaking care to what is at the present time one of the best varieties of yellow corn grown. It has a medium sized, solid, compact ear, straight rows (16 to 20 on an ear), holding its shape rell to the ends, which are well filled. The cob and shank is small, making it a to the ends, which are well

The most popular variety in all corn shows and fairs. If your strain of Reid's Yellow Dent has run out send for our improved selection of this corn, bred for solidity, uniformity, development of tips and butts, percentage of shelled corn, and vigorous growth; a prize winner and will show your neighbors what can be done in the way of raising corn. In fact, they will be wranting seed from you and will be willing to pay you fancy prices.

Price, postpaid: Ear, 40c; lb., 30c; 7 lbs. (enough to plant 1 acre), $\$ 2.00$.

\section{Gold Standard Early Leaming $(90-100 \mathrm{DAYS})$}

The King of Cattle Corn-98 Years OId.

Originated in Ohio 98 years ago by Mr. J. S. Leaming and introduced into this part of Iowa more than fifty years ago by pioneer settlers who came here from Ohio. Even at that early date, long before scientific corn breeding was talked of, it was noted for its uniformity and purity; also, its distinct characteristics, and was extensively known by stock feeders. Since its fist introduction many strains of dent corn have been started from this oldest known variety, but during all the rears we have grown it original type, and by careful selection year after year have greatly improved this excellent variety.

Early Gold Standard Leaming is a pure and distinct variety of beautiful golden yellow color. It grows a strong rugged stalk, 8 to 12 feet high, with very profuse, broad blades, making it one of the best fodder and ensilage varieties. Ears contain 16 to 20 rows of broad, thick, deep, wedge-shaped grains, set solidly on a small cob; usually two ears, 8 to 12 inches long, to the sta!k. The grain is rich in protein and oil, making it the ideal corn from the feeder's standpoint and the immense tonnage of fodder it produces mak

Price, postpaid: Ear, $40 \mathrm{c}$; lb., $30 \mathrm{c} ; 7$ lbs. (enough to plant 1 acre), $\$ 2.00$.

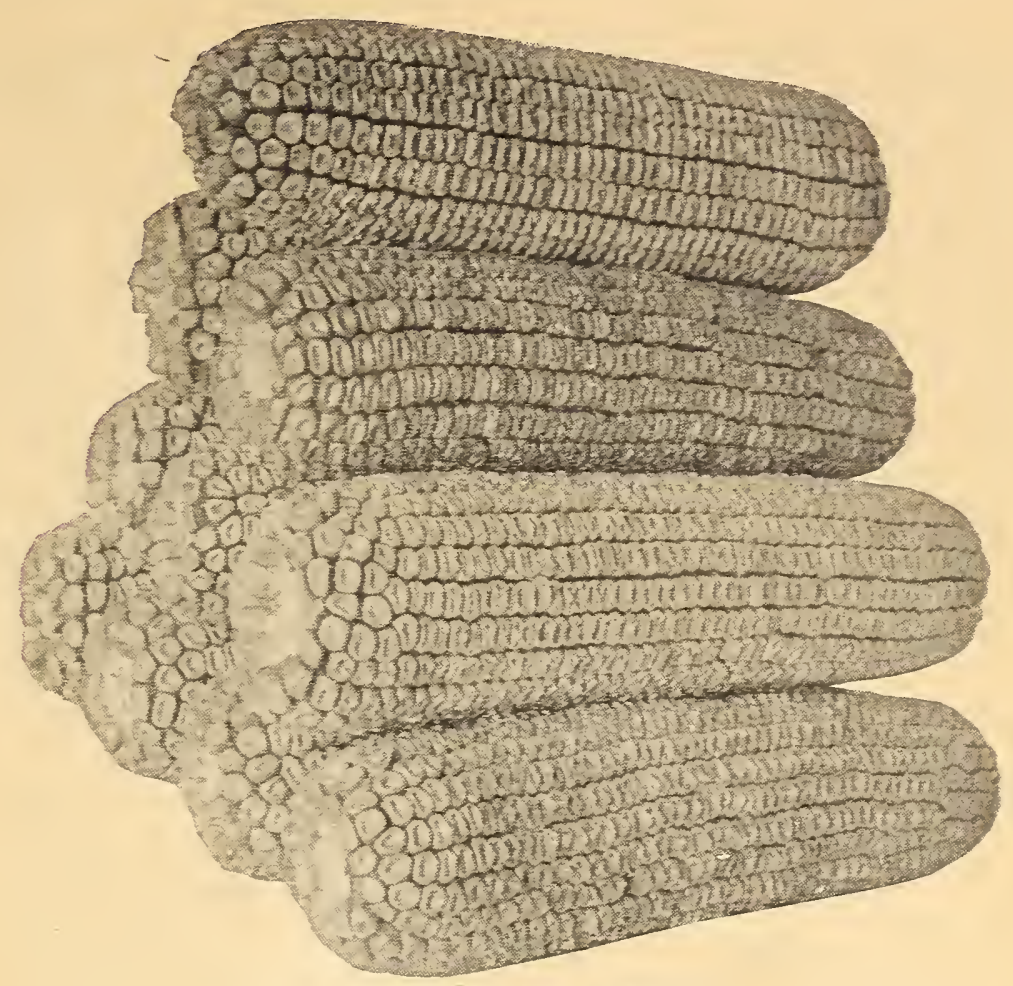

Reid's Yellow Dent

Ask for type samples of any varieties in which you are interested

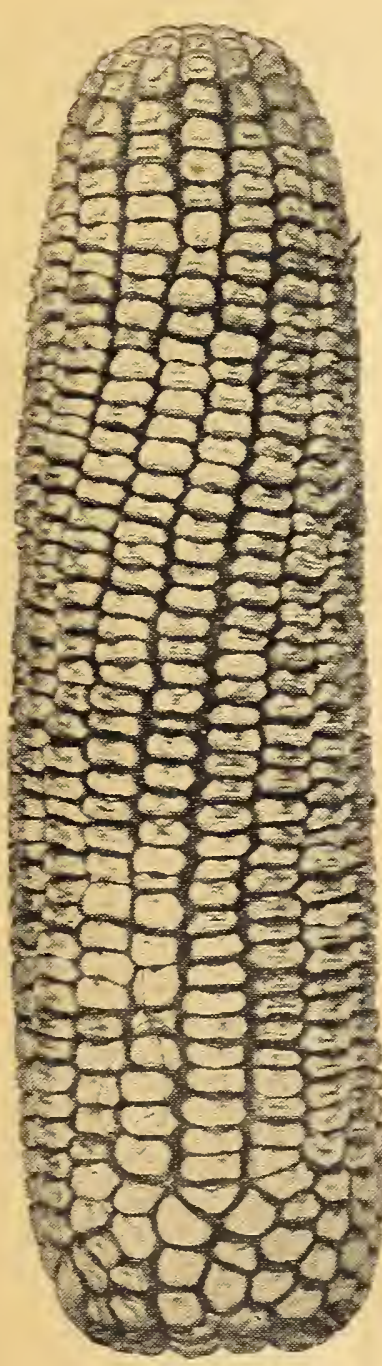

Iowa Gold Mine

\section{Queen of Nishna ${ }^{(75.85 \mathrm{DAYs})}$}

\begin{abstract}
A Thoroughbred Yellow Dent Corn for Northern or Late Planting.
Originated by us and though it was almost perfection itself when we first cataloged it, we have constantly tried to improve it in every possible way by culling out all barren stalks and increasing the number of ears to the stalk. During the past 12 years we have had vields ranging from 60 to 94 bushels per acre on our experimental farms, or over 20 bushels per acre better yield than under identical conditions. We have frequently gathered good, sound solid well matured corn in 75 days from the time it was planted and have shelled corn from it in 85 days from planting.

For an early feeding corn Queen of Nishna has no equal. It makes an ideal ensilage corn for the northern farmer, maturing before frost and making a large yield. For the eastern farmer the same may be said, adding that it makes a fine feeding corn. In the south, this corn has taken the place of th well known June corn, making a fine yield and being a strong drouth resister.

Price, postpaid: Ear, 40c; lb., 30c; $7 \mathrm{lbs}$. (enough to plant 1 acre), $\$ 2.00$
\end{abstract}

\section{Iowa Gold Mine (95-110 Dars)}

Yellow as Gold Itself-Best Medium Early Variety.

"The Corn that made Iowa famous." Probably more widely known than any corn grown, and claimed by many to be the very best early corn in the world, one of the earliest, purest yellow, and deepest grained corns. Our strain is singularly free from barren stalks and is an exceedingly heavy yielder, every stalk bearing one to two good ears, 8 to 10 inches long. Last year afte selecting and preparing our seed stocks from our crops of this variety we shipped the refuse corn, including tip butts and cull ears to the Chicago market where it graded No. 2. This speaks mighty well for the quality of our Seed Corn.

Price, postpaid: Ear, $40 \mathrm{c}$; lb., $30 \mathrm{c} ; 7 \mathrm{lbs}$. (enough to plant 1 acre), $\$ 2.00$.

\section{Improved Pride of the North $(86.90$ DAYS)}

This early corn was originated by A. L. Goddard, of Kossuth County, Iowa (one of the extreme northern counties of Iowa), thirty years ago. It is great favorite in the extreme northern states. A pure yellor dent, ears from seven to nine inches long with small cob and deep kernels, ears carrying from 14 to 18 rows. Will ripen and mature any place in from 80 to 90 days: can be planted as late as June 25 th and make itself by September 15 th. Good soil is and usually produce from 30 to 40 bushels per acre.

Price, postpaid: Ear, $40 \mathrm{c} ; 1 \mathrm{lb} ., 30 \mathrm{c} ; 7 \mathrm{lbs}$. (enough to plant 1 acre), $\$ 2.00$.

For Bushel and Larger Quantity Prices of Seed Corn See Current Price List.

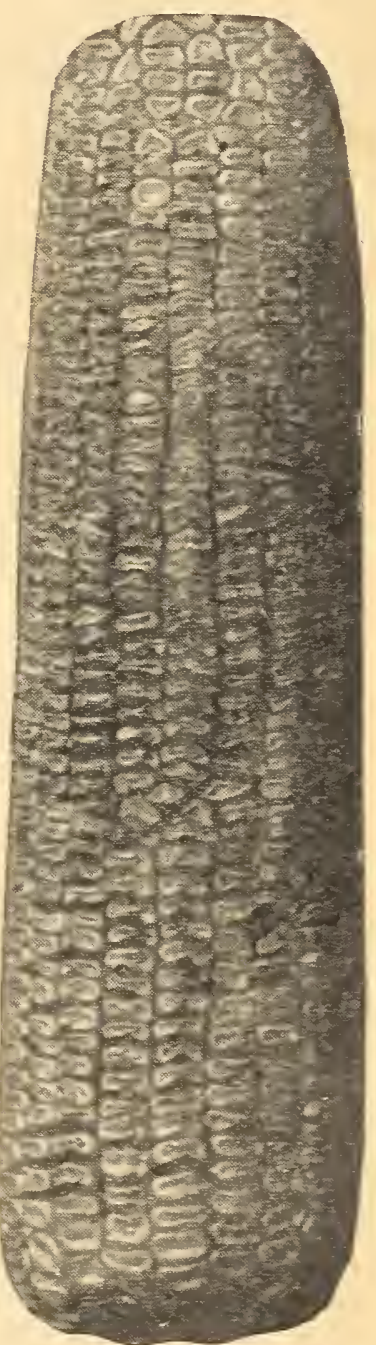

Queen of Nishna 


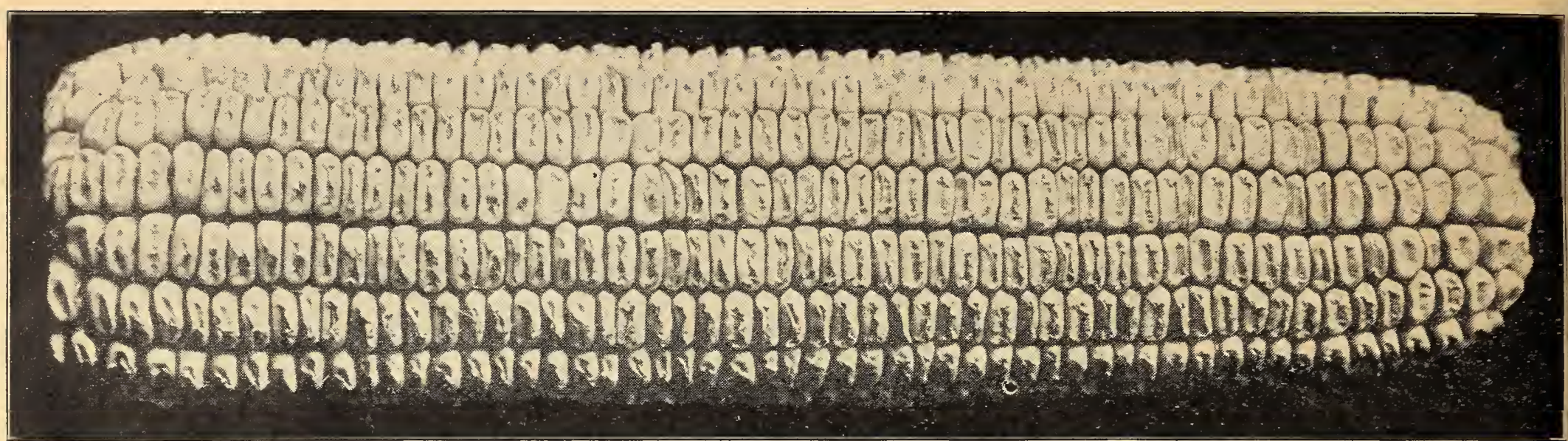

Iowa Silver Mine

\section{Pure Genuine Iowa Silver Mine (90-100 DAYS)}

The Pure, Genuine Silver Mine Corn Bred and Grown Under Isolated Conditions Especially for Seed Purposes.

One of the greatest yielding white varieties, drought proof, of extreme vitality and does better on old, poor or hill land than any other variety. Early to mature, a big yielder and unexcelled for feeding, ensilage or fodder purposes. It is adapted to a wide range of conditions and is a great success in the north, south, east and west. It makes good where others fail and brings satisfaction to the farmer who plants it. Because of the great popularity of this corn thousands of bushels of white corn are offered and sold every year under the name of Iowa Silver Mine which bears no likeness to it. Our Stock is Pure.

The stalk is medium in height, ranging from 7 to 10 feet (dependent on the land, hill or bottom), very leafy broad blades; type of corn even and uniform ears running from 9 to 12 inches in length; 16 to 20 rows pure white kernels solidly set on a medium small cob. Matures in from 90 to 100 days in good colidy set on

There is scarcely a township or neighborhood where corn is grown but what some of your neighbors can tell you about Iowa Silver Mine and the splendid results obtained from it. In view of this we do not deem it necessary to print even a partial list of the thousands of testimonials we have received pertaining to this corn.

Price, postpaid: Ear, 40c; lb., 30c; 7 lbs. (enough to plant 1 acre), $\$ 2.00$.

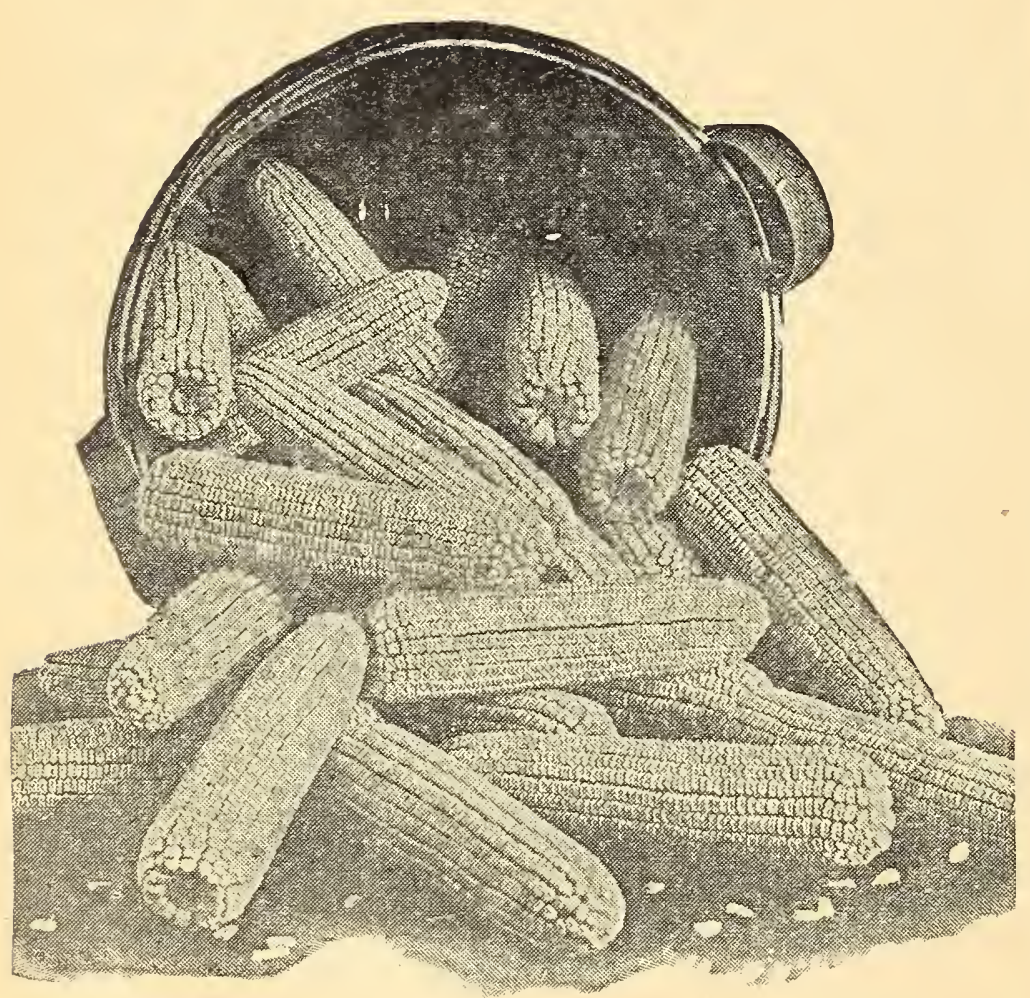

Boone County White

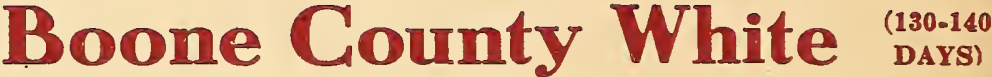

A Great Favorite With Southern Planters.

A large white corn, perhaps the largest stock and largest eared field variety grown, either white or yellow, and a great favorite with some of our customers where the seasons are long enough for it to mature. The stalks grow from 9 10 to 12 feet in height; ears from 9 to 12 inches in length; 16 to 22 rows deep grains on medium large cob. Like all white varieties, it does better on old or thin soil than yellow sorts, and gives corresponding yields on good, rich or bottom land. With favorable seasons, where it has plenty of time to mature it is a valuable and very productive variety; say the states of Kansas, Missouri, southern half of Illinois, Indiana and from there south to the Gulf Coast states. Our seed stock is pure, and especially fine, well matured and can be relied upon to ditions.

Price, postpaid: Ear, 40c; lb., 30c; 7 lbs. (enough to plant 1 acre), $\$ 2.00$.

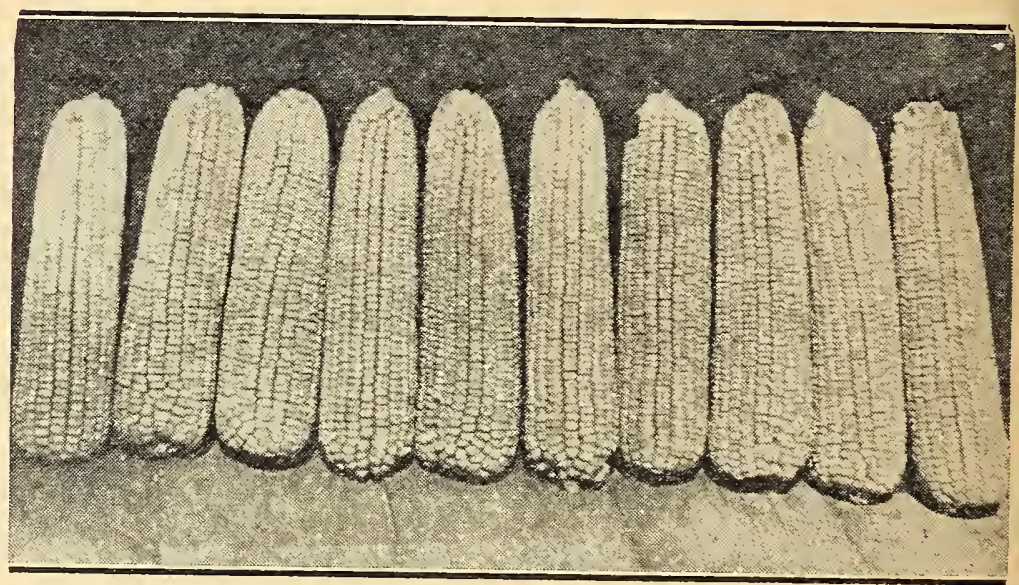

Silver King

\section{Silver King}

A Superior 90-Day Variety Suitable for Northern Planting.

Attention was first directed to Silver King Corn through the efforts of Mr. H. J. Goddard of Winnishiek County, Iowa, an extreme northern county of Iowa (bordering on the State of Minnesota), who in his day ranked as the one foremost corn breeder in Iowa. Its origin can be traced back to Indiana for it was brought from that state to Lafayette County, Iowa, in 1862. In $1869 \mathrm{Mr}$. Goddard secured a half bushel of this seed. The possibilities of developing a superior type or variety from the stock so appealed to him that he continued to grow it, selecting each year the type of ear which came nearest his ideal. This has had much to do with the present uniform type of the corn. While he gave special attention to early maturity, at the same time he selected an ear of good size, deep kernels and comparatively small cob, and with !ittle space between the rows.

In appearance the corn is a beauty. Ears averaging 8 to 10 inches, always filled out to the tips, and very uniform in size and type. The corn is pure white in color with good length kernels set compactly in straight rows. A strong grower, early enough to mature as far north as St. Paul, Minnesota, and is especially adapted to resist cool weather. It has a decided double ear

We feel that we can hardly rate the value of this corn too high. It gets ripe and produces the yield. Professor Moore of Wisconsin Experiment Station says, "Push it hard, it will stand it." Hundreds of the leading farmers of Northern Iowa, Minnesota and Wisconsin swear by SILVER KING. The greatest yield for Silver King thus far reported and the yield record for Wisconsin all varieties is $1376 / 10$ bushels per acre. This was the amount of shelled corn production on one acre of ground in 1913, by Heiron Block of Racine County, in the acre contest.

Price, postpaid: Ear, 40c; $1 \mathrm{lb}$., 30c; 7 lbs. (enought to plant 1 acre), $\$ 2.00$. 


\title{
Wallace's Favorite White
}

\author{
(110-120 DAYS)
}

We place this superior variety of corn before our customers for the 16 th year with renewed assurance that experience has demonstrated and proven it
is one of the best, highest yielding varieties of all our introductions. While we do not claim it will make two, three or four hundred bushels per acre, we know it can be relied upon to yield as many bushels of good, sound corn per acre inside of 120 days as any variety to be found and if planted on good ground will yield from 90 to 100 bushels per acre, and even more under perfect conditions.

The stalk is large, strong and robust, usually from 8 to 10 feet high, with long, broad leaves, extending from joints, which are close together and producing one and two good ears to the stalk, running from 8 to 12 inches long, with 16 to 20 rows of grains on white cob. Surely this corn will not disappoint our best expectations. It is not only good for the grain it grows, but one of the best combination varieties for grain, fodder and ensilage purposes there is
grown.

Price, postpaid: Ear, 40c; 1 h., 30c; 7 lbs. (enough to plant 1 acre), $\$ 2.00$.

\section{St. Charles White}

The Famous Ensilage for the Dairyman.

The cob is red and the grains white. Much clearer in color than that of the white cob varieties. Because of this exceptional whiteness, it is much in demand by millers for the finer grades of meal. You will get a good yield of shelled corn per acre as it usually overruns 5 per cent in she!ling. Its broad succulent leaves make it especially desirable for fodder and ensilage. Everywhere, both in the North and in the South, this is the great corn for ensilag and fodder; even Manitoba is growing it for this purpose. A heavy cropper and will produce from 40 to 50 tons per acre of the very best feed.



Field of St. Charles white

The grain is deep, slightly rounded and medium rough. Ears are from 9 to 12 inches long, 7 to 8 inches in circumference and cylindrical in shape.

We can supply you with some extra fine seed of this variety, all tested and guaranteed. If you want to grow ensilage corn, don't buy inferior seed offered at low prices. Buy our regular grade of high testing seed corn and you will have the cheapest seed you can buy. You take no risk in planting our seed as it is all sold subject to your test and approval.

Price, postpaid: Ear, 40c; $1 \mathrm{lb} ., 30 \mathrm{c} ; 7 \mathrm{lbs}$. (enough to plant 1 acre), $\$ 2.00$.

\section{Imperial White}

(90-100 DAYS)

The Best for Poor, Thin Soils.

A variety regarded with great favor and admiration the country over, especially in the South, where it is grown extensively for main crop, and in the Eastern and New England States, where grown for ensilage and fodder purposes. Without doubt one of the best varieties for a combination crop for grain fodder and ensilage purposes there is grown or in existence.

We originally obtained the seed of this variety from an old German farmer, who was one of the most successful corn growers in central western Illinois, and we first introduced it twenty-one years ago, since which time we have a great favorite and success.

It is pure white, with red cob-a sign within itself of great vitality; ears 16 to 24 rows of deep grains, firmly set on a small red cob, producing two to

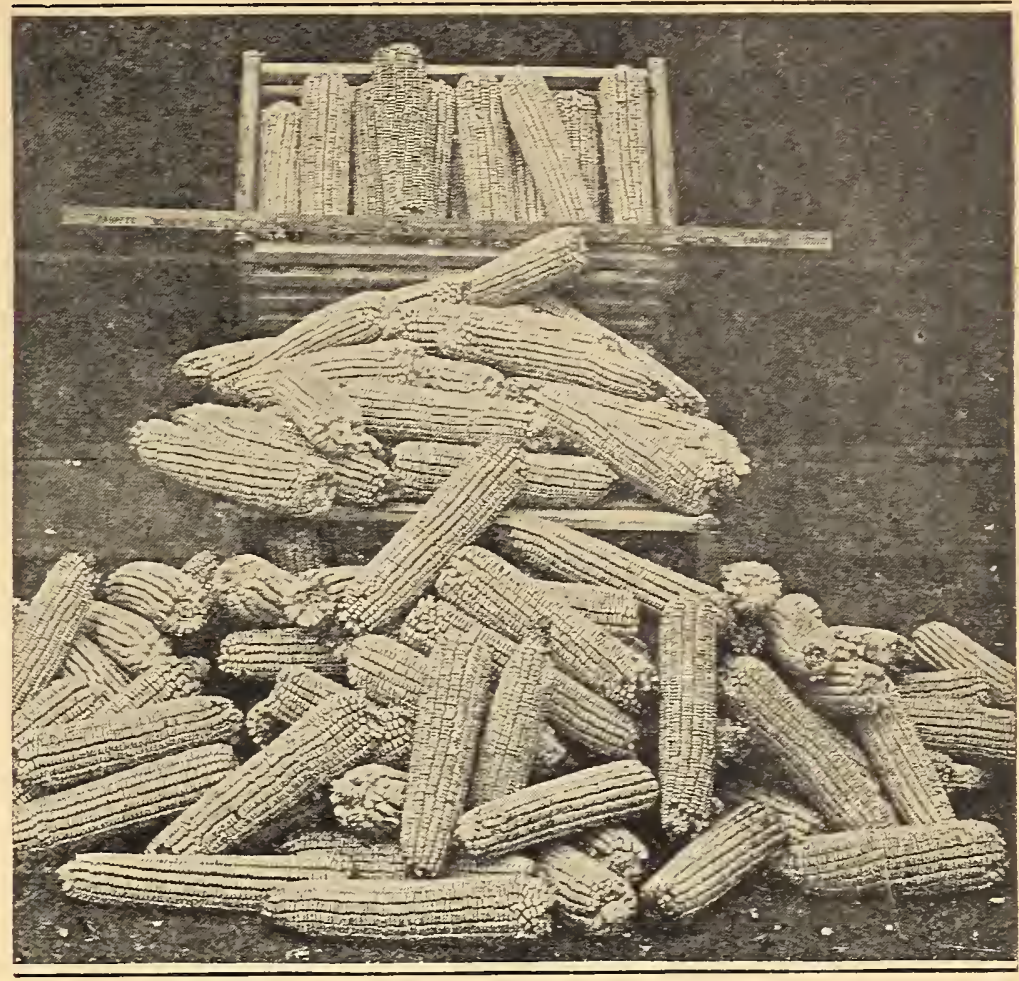

Wallace's Favorite White

three good ears to the stalk. The stalks are short and heavy, averaging from 7 to 10 feet in height, with a large amount of foliage. Does well anywhere and everywhere, and is especially adapted to old, poor and thin land, and will make a good crop where other sorts fail. It is also especially adapted to the eastern and southern states, and where early drouth and parching hot weather of ten injures other sorts. It matures safely anywhere in from 90 to 100 days; is very solid and compact. We can heartily recommend this corn to our cus print hundreds of testimonials from those who have tried it, if space would permit, all verifying what we have said of this splendid variety of corn.

Price, postpaid: Ear, 40c; lb., 30c; $7 \mathrm{lbs}$. (enough to plant 1 acre), $\$ 2.00$.

\section{Improved White Cap Bloody Butcher (90 Dars)}

For Late Plantings, Replantings and Early Feeding.

A very early, heavy yielding variety of 90-day corn, one of the best, most hardy and most certain to always make a good crop, wet or dry, rich first listed it only as an extra early variety, yielding 30 to 50 bushels under favorable conditions. Since that time however, it has responded so readily to our careful selection of seed stocks that our strain is now yielding from 60 to 80 bushels per acre under most all kinds of conditions.

A distinct variety, easily distinguished from all other varieties. Grains are bright red in color with a white cap and smooth dent, set on a snowy white cob; depth of kernel only medium, almost as broad as it is long. Ears long and slim, running from 12 to 16 rows, and many of them 15 inches long-perhaps running more uniform in size and length than any other variety

Price, postpaid: Ear, 40c; lb., 30c; 7 !bs. (enough to plant 1 acre), $\$ 2.00$

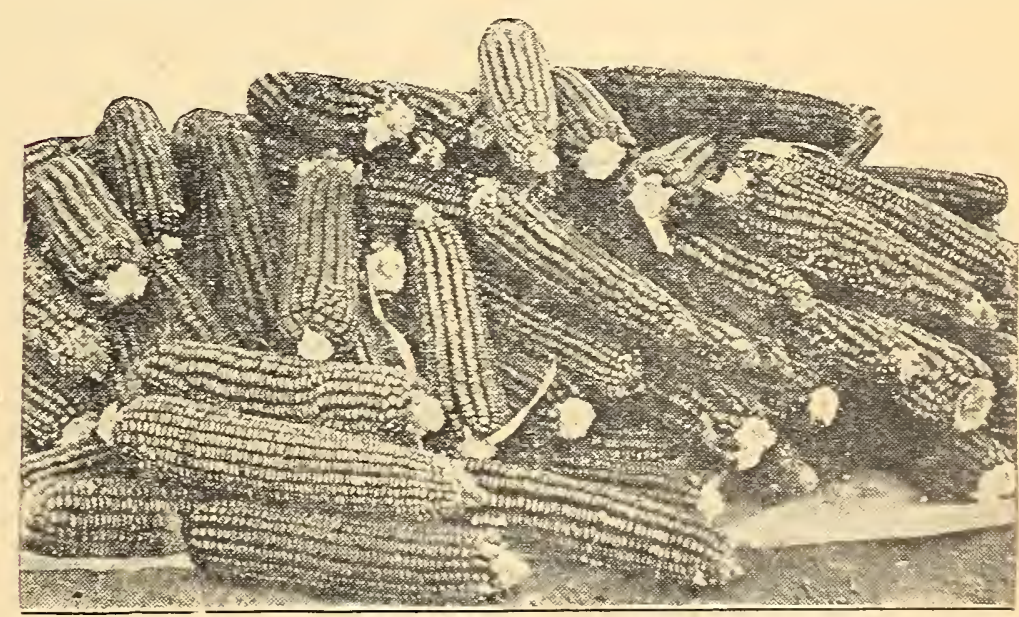

Bloody Butcher 


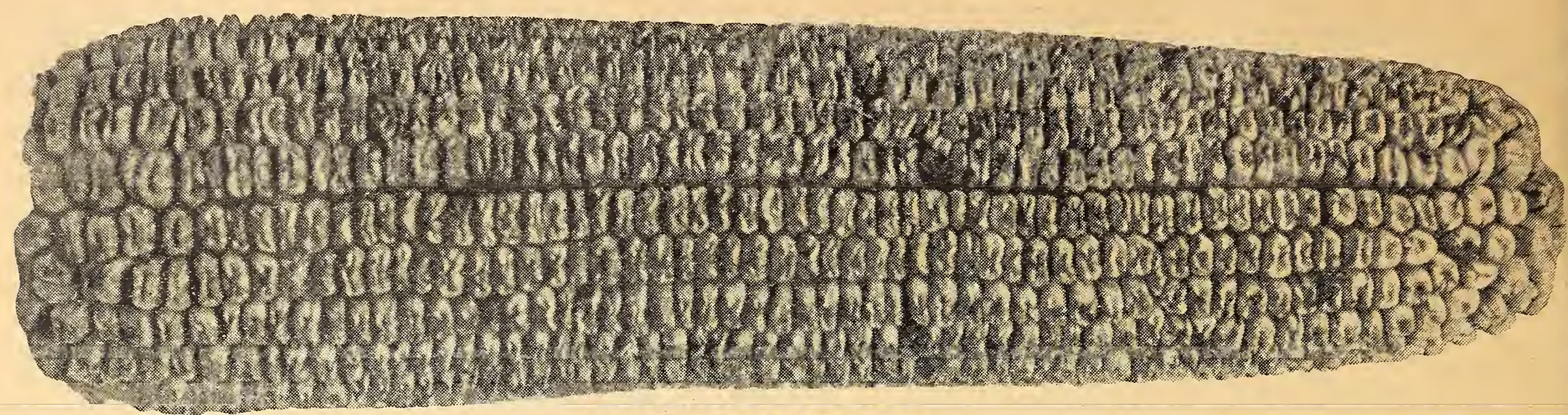

\section{Improved Calico Corn}

\section{Improved Calico Corn}

The old-fashioned kind, always very popular as a feeding corn, and for many years we have had a great demand for it from stock feeders. So great has been the demand that we have given greater attention to it the past few years than in former years. Thirteen years ago we found a superior type of this corn, grown by a leading corn breeder in Kentucky, from whom we obtained seed, which has proven a wonder. Without fear of contradiction we can say we have the highest and best strain of this corn that can be found anycan say we have the highest and best strain of dhe deep grain and small cob, thus where. The strain is of the large-eared kind, deep grain and small cob, thus 7 to 8 inches in circumference. A combination in color of red, white and yellow striped. Full of protein and very rich; stock like it and eat in preference to other corn. To all those in want of one of the best corns for stock feeding, we are in position to supply with the very best of seed.

Price, postpaid: Ear, 40c; lb., 30c; 7 lbs. (enough to plant 1 acre), $\$ 2.00$.

\section{Mammoth Longfellow Flint}

An eight-rowed yellow flint variety, with ears from ten to fifteen inches long, 2 to $21 / 2$ inches in diameter, and well filled out to the extreme end of the long, 2 to $21 / 2$ inches in diameter, and well filled out to the extreme end Is well adapted to the northwest. Has been grown in northern Minnesota and North Dakota for fifteen years with great success and complete satisfaction. Very prolific, many. stalks have two and very often three good ears. Stalks average seven to nine feet in height and make excellent fodder. Very few suckers.

Price, postpaid: Ear, 50c; lb., 40c; 7 lbs. (enough to plant 1 acre), \$2.25.

\section{Improved Stowell's Evergireen}

If there is a variety of corn that is entitled to a whole page in this book, as a general utility crop, for the table, for canning purposes, for nutritious food for the human family and all kinds of stock, from the hog to the horse, it is Stowell's Evergreen Sweet Corn. It matters not what the cost of the seed, even at $\$ 10$ per bushel, it will pay every farmer to plant a few acres, enou $\mathrm{h}$ to carry his stock, whether many or few, through the late summer and early fall months when pastures are dead or dried up. As a green fodder fed in this way one acre will furnish as much feed as eight acres of grass. It will make you from 15 to 30 tons to the acre.

See current price list for prices.

\section{Eureka Ensilage}

Popular as an Ensilage Corn in Northern and Eastern States. This not only grows the tallest and is the most leafy of the ensilage corn, but is as well productive of ears, yielding often 100 bushels of corn to the acre in latitudes permitting it to grow to maturity. Ears are long and slender, with large grains of the highest quality. Will, under ordinary conditions, make more fodder and ensilage than any other variety grown.

Price, postpaid: Ear, 40c; lb., 30c; 7 lbs. (enough to plant 1 acre), $\$ 2.00$.

\section{Sanford's Early White Flint}

Considered the best flint corn on the market. The ears are of unusual length, 12 to 15 inches, and handsome shape, flinty white color. Plants of
sturdy, vigorous growth; leaves are very broad and succulent, and it is theresturdy, vigorous growth; leaves are very broad and succulent, and it is thereusually bear two or three long ears.

Price, postnaif: Far. 50c; lh., 40c; 7 lbs. (enough to plant 1 acre), \$2.25.

\section{SEED CORN WARNING}

The past season has been very unfavorable for the production of Seed Corn on account of extreme wet weather and early frosts. Not since 1917 has their been such a shortage of good seed, not only in Iowa but throughout the entire Corn Belt.

No matter where you buy your seed insist on a germination and moisture content guarantee and do not buy corn that has not been kiln dried. We can and do guarantee to furnish you with satisfactory seed, seed that has been carefully selected, dried and tested.

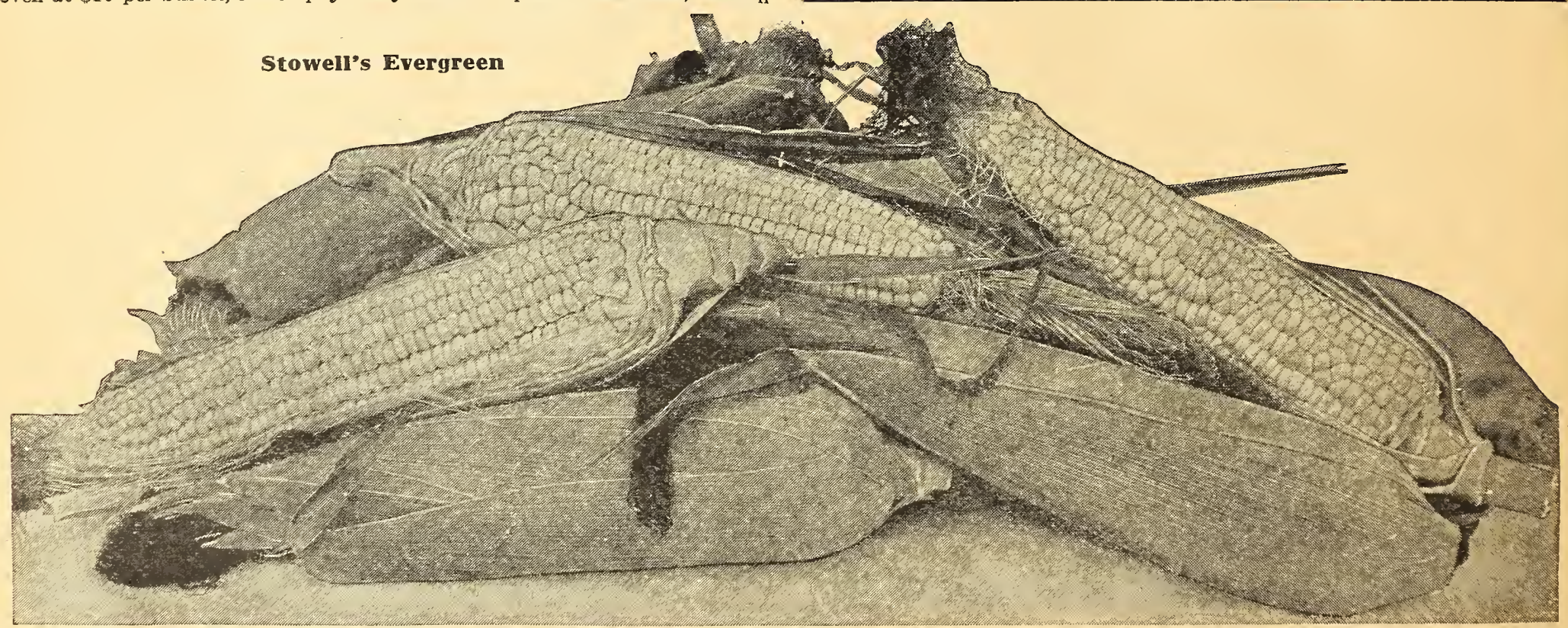




\section{Dependable ${ }^{66} J e f f e r s o n$ Brand"9 Grass Seed}

Did Jou notice the picture of our new warehouse and office buildings shown on the front cover page? These are the buildings formerly occupied by the Zeller Seed Co. We took possession of them July Ist, last, and are deroting the entire warehouse to field and grass seeds. Let us tell you about this grass seed business of ours, then, if you are at all interested in grass seed you will want to see our samples and prices.

\section{Location a Big Asset}

Previous to moring to Jefferson from Shenandoah and the appointment of Mr. G. W. Mackey as General Manager the Company had specialized on Seed Corn and had handled Grass Seed only as an accommodation to theiSeed Corn customers. The new location offered unlimited possibilities as a Grass Seed center. Jefferson is located just a fer miles north and west of the center of the State, on the main line of the Chicago \& Northwestern and It. Paul Railroads. These two roads, running east and west, and north and south, respectively, have a number of freight and express trains each way every day. In fact, there's a train through Jefferson every 20 minutes of the day and night. This gives us unusually quick service to all points east, rest, no:th and south, a service that is rery essential in shipping grass seeds. It also gives us easy a service that is rery essential in shipping grass seeds. cleaning and redistributing at a minimum haulage expense.

\section{We Go North for Most of Our Seeds}

Mr. Macker, the new General Manager, was quick to see the opportunities thus offered. Seven years ago he started in to organize a Grass Seed department and he has succeeded in building up a pronderful business in this line. $\mathrm{He}$ is, himself, an expert Grass Seed man, being considered one of the most able buyers in the business, and he has brought into the business as associates, other men with a thorough knowledge of all matters pertaining to field and grass seeds. At harvest time and before, these men are in the field as buyers. They go to where the best seeds are produced; this State for Clovers and TimTho Clorers; the Northrest for Alfalfa and Sreet Clovers; and so on through the Clovers; the Northrest for Alfal
entire list of field and grass seeds.

\section{We Neither Buy Nor Sell Noxious Weeds}

Our cleaning plant is equipped xith modern, electrical driven machinery throughout, including Clipper mills and screens of all sizes and descriptions. In no way can it be compared with the ordinary "fanning mill" equipped elevators. Even so, our buyers take a large part of the burden from the cleaning mills. We do not buy all seeds that are ofiered us. They must be reasonably clean and pure if our buvers even consider them. No seeds of ans kind that contain ant one of the noxious meeds such as buckhorn, dodder, thistle, quack grass, etc., are ever bought and brought into our house. This, in accordance with our policy of bandling but one grade, and that the best. This one grade, the best the market affords, is known by dealers and planters everyone grade, the best the mark.

\section{Get to Know "Jefferson Brand"}

"Jefferson Brand" seeds are selected seeds-selected and gathered by men who know seeds and from regions most farorable to the growth of each variety. They are cleaned and recleaned by the most modern machinery here in (the shrunken and shrived grains are removed, lea ving noth

right size, plumpness, purity and germinating qualities. see them for yourself: We'll gladly send identical samples, or, we'll accept and ship your order rith the distinct understanding that the seeds must be entirely satisfactory to you; if they're not, send them back, and re'll refund your money and pay all transportation charges

\section{What About Lower Grades?}

Of course, despite the most careful buying, we sometimes get seeds that bill not grade" Jefferson Brand." Maybe it is to finish flling a car, o: a small lot taken in with 2 large lot of good seed. Then there are the screenings taken from the seeds which are cleaned up to the "Jefferson Brand" standard. Fes, Te, like all othe: seedsmen, do have low grade seeds in our house at times but dealer and planter customers. They are offered out and sold to seed concerns not wanting the best seeds, but seeds that can be sold at a lor price.

\section{About Prices}

Owing to market fluctuations, we're unable to quote firm prices in this book but issue a Current Price List from time to time. Ask for it, also identical samples of the seeds in which you are interested. You'll sare moner", equal quality considered.

\section{If You Live in Iowa}

Jefferson Seeds are sold by dealers in nealy every locality in Iowa. I rour dealer is, handling Jefferson Seeds, see him early: If he doesn't handle our seeds don't buy until you write us direct and get our samples and prices.

\section{The Sign of GOOD SEEDS}

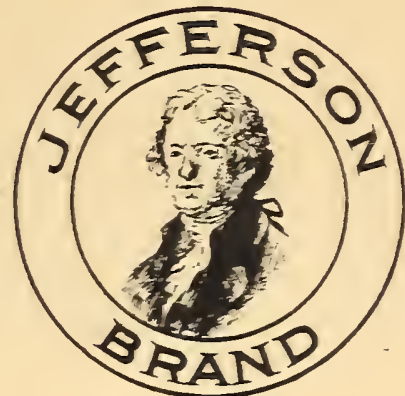

Your Crop Insurance

\section{Why? Prices Are Higher This Year}

RED CLOIER SEED PRODCCTION LESS THAN 1922

Production, According to the U. S. Department of Agriculture, is 45 Per Cent of Last Year.

Winter-killing and generally unfarorable weather last summer and this spring, according to the U. S. Department of Agriculture, caused a marked reduction in the acreage and rield per acre of red clover seed. The production of medium red clorer is expected to be about 45 per cent of last jear's crop. Ilammoth Ped clorer prouction is also much below that of last jear. There was a big decrease in the acreage in every important red clorer seed producing State except Idaho. In general yields per acre in the sereral States did not show such large reductions from last yea: as did acreages. Almost every state, horever, indicated a smaller yield per acre than last year.

ALSIKE SEED PRODCCTION LESS THAN LAST YEAR.

U. S. Department of Agriculture Estimates the Crop as 70 Per Cent of Last Year's Crop.

According to a report recently issued by the U. S. Department of Agriculture, the production of alsike clorer seed this year is 70 per cent of the 1922 crop.

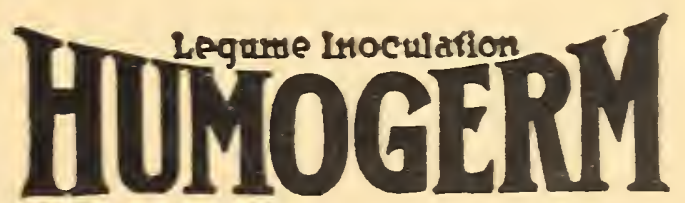

Cultures of Nitrogen for Bigger Crops-Better Soil.

Every time you plant any kind of field oz garden beans, peas, clore:, peanuts, vetch alfalia, inocculate the seed with this cluture of nitrogen. Cnless your soil is unfarorable, having the proper bacteria ond, and great numbers of nodules on roots which deposit in your soil nitrogen fertilize: (nitrates) worth $\$ 20$ to $\$ 30$ an acre as fertilizer for grain, cotton, tobaceo, fruit or other crops grown on the land afterward.

\section{INEXPENSIYE-RELIABLE-EASY TO LSE}

Not only is it important that rou inocculate rou seed, but it is just as important that you use the best cultures you can get. What in treated humus, in cans, at an exceptionally low price. It is put up for us in laboratories that specialize on preparing these cultures. Te strongly recommend it and al wars have fresh Lespedeza. Bur, Japan, and other clorers: Sor. Tolvet Lima and all beans; Cowpeas, Sweet Peas, Beggarweed, Sesbania, Peanuts, Vetch, etc. treat. The 1-bushel size will inoculate 1 bushel of seed; if planting more than I bushel of seed per acre, 1-bushel size Humogerm will take care of the

Prices, postpaid: 21/2-bu. size, $\$ 2.25 ; 1$ bu. $\$ 1.00$. 1/2 bu, 60c; 1 1 bu., 35 Special garden size that will inoculate $15 \mathrm{l}$ bs. peas, beans or sweet peas, $25 \mathrm{c}$ 



Field of Red Clover

\section{Jefferson Brand Clovers}

Jefferson is fast becoming the Clover market of Iowa. Located almost in the center of the State and on two great railroads running each direction through our little city, we have easy access to all important producing sections. We also have the equipment and the "know how" to properly grade and clean seeds. In short, there's no seed house in a better position to supply the very best quality seeds at reasonable prices.

Under our trade mark, "Jefferson Brand," we send out to our dealer and planter customers the hardiest, biggest-yielding and purest seeds produced, all fully tested and guaranteed, with every bag plainly marked. You can buy all fully tested and guaranteed, with every bag plainly marked. You can buy

Ask to see samples of Jefferson Brand Clover and Grass Seeds. You'll then see why we have the continued business, plus the good will, of all who have ever bought "Jefferson Brand Seeds." We need your business too, and, given are both safe and profitable to buy.

\section{Special Notice}

Italian Red Clover seed has been declared of doubtful value for seeding in certain sections of the United States by officials of the United States Depart-
ment of Agriculture and by certain state experiment stations. The status ment of Agriculture and by certain state experiment stations. The status
of Italian Red clover seed is of considerable importance to seedsmen inasmuch as the seed trade depends for the successful conduct of its business upon giving adequate service to customers, which, among other things, means selling seed stocks of quality that will give satisfaction to purchasers. There is not sufficient clover seed produced in the United States to take care of home demand and the deficiency has always been made up by the imported seed, a large portion of which has come from Italy. If this Italian clover seed is not adapted to certain sections of the United States because of its lack of hardiness, seedsmen in the corn belt states, which is the area of non-adaptability mentioned by the customers. The department advises the farmers that when buying red clover customers. The department advises the farmers that when buying red clover seed they ascertain where the seed was grown and to purchase only home-grown
seed whenever possible. Doubtless this recommendation will be given wide circulation in the publication going to farmers. The department has not completed its tests to detemine ther fitness of Italian clover seed for all sections of the country, but the results of the experiments to date seem to indicate that it is not adapted to seeding in the corn belt states. - The Seed World, Chicago.

We have never had nor do we expect to have a single pound of other than domestic grown seed in our house. This year with the Clover crop far below normal we have succeeded in securing finest quality Iowa, Wisconsin, Illinois and Northern Indiana grown seed. All is of good quality, testing high in purity and germ

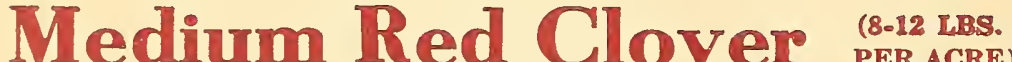

Regarded as the most valuable of the Clover family. Sometimes called June Clover and is a dependable all-round variety for farmers and stockmen. It makes two crops each year. The first is usually cut when it is in blossom for hay; the last crop may be harvested for seed, cut for hay, or plowed under to add fertility to the soil. It may be sown either in the spring or fall, and where no other grasses are used, at the rate of 8 to 12 pounds to the acre, according
to quality of seed used and condition of the soil. Clover adds greatly to the fertility of the land on which it is grown. It does not exhaust the soil, but enriches it. It pays always to buy the best quality of Clover seed which can be obtained. Even though the first cost is twice as much as cheaper seed, it will be found in the long run that inferior seed is the most expensive, not only on account of less hay or seed being produced from it, but from the fact that
one's land becomes infested with weed seeds which decrease the value of the land on which they are growing.

It has been demonstrated time after time that crops following a growth of Clover are larger and of better quality than when grown on land which has

produced the same crop for a series of years. Clover should be rotated with grain crops every three to five years. The small nodules or bacteria which cling to the rootlets possess the power to draw the nitrogen from the air and store it in the soil, where it is most needed and where it can be drawn upon by subsequent crops. It is well to sow Clover with every crop of hay. It serves to keep the ground free from weeds, restores fertility, and may be pastured in the fall, or will repay the grower even if put to no other use than to be plowed under as a green fertilizer.

Ask for identical samples and current price list.

\section{Mammoth Red Clover \\ (8-10 LBS. PER ACRE)}

Grown largely for pasture and to restore fertility to depleted soils. It makes good hay if cut soon enough, although it has a coarser stem then the Medium Red Clover. Mammoth Red Clover supplies fine grazing for stock. It sometimes yields more seed than Medium Red Clover. Being a rank grower, it is very valuable for fertilizing purposes. The foliage, flower and stem are darker in color than the Medium Red Clover. It ripens later, and makes are darker in color than the Medium Red Clover. It ripens later, and makes
only one crop. Especially valuable on light, sandy lands. Eight pounds of only one erop. Especially valuable on light, sandy
Jefferson Brand seed are sufficient to sow an acre.

Samples and current prices gladly sent on request.

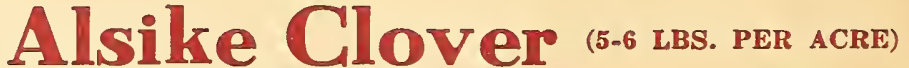

This wonderful Clover is becoming very popular throughout a vast area of the country. It will grow successfully over a wider range of soil and climates than any of the other Clovers. While it is especially adapted to cool, moist climates, it is capable of adapting itself to many adverse conditions and is very popular for growing on soil slightly acid where no other Clover can be grown.

Alsike is a perennial, and because of this characteristic is especially valuable for growing on land where one wishes to secure a permanent pasture or meadow. Because of its not being susceptible to heaving and winter-killing it is a very valuable crop to grow where climatic conditions make it hard to grow other Clovers.

Alsike is especially valuable in reclaiming wet lands, and will produce a wonderful crop where nothing but swamp weeds formerly grew. It is not injured by overflowing, providing water does not stand upon it for too great a length of time, and it has been found to be of great importance in reclaiming districts through which drainage canals have been constructed, as it seems to be especially adapted to the low lying soil, and materially aids in getting such tracts of land in shape for future cultivation.

Alsike when grown in combination with grasses makes one of the best combinations either for hay or pasture that can be grown. A perennial the same as most grasses, and this feature is especially commendable for growing it in combination with ast crops that can be grown for hay or pasture. It not only forms a thick bottom, thereby increasing the yield, but being a legume it greatly increases the feeding value of the crop.

Much more Alsike should be used. The seed is smaller in size and 5 to 6 pounds makes a good seeding. One bushel of Alsike will sow as far as $11 / 2$ bushels of Red Clover. We have some extra fine bargains in Alsike Clover. Write us at any time for samples and prices.

\section{White Dutch Clover}

Commonly known as White Clover, that makes such good pasture and is so valuable for lawns. The hardiest of all Clovers and accommodates itself to all manner of soils. Will endure the extreme heat and dryness of summer better than blue grass. Will not tramp out. Keeps soil from washing. Seed s scarce, hard to get and very

See Current Price List for today's prices. 


\section{Sweet Clover-The Real Money Crop}

\section{A FEW FACTS WORTH KNOWING ABOUT THE KING OF LEGUMES.}

1. Sweet Clover will produce a greater cash income per acre than any other crop.

2. It is the greatest soil builder known, not only because of its ability to take nitrogen from the air and store it in the nodules on the roots, but because of the large amount of humus added to the soil from the decay of its roots.

3. Sweet Clover will grow in soils too low in humus content for any other legumes.

4. The large roots of Sweet Clover facilitate drainage and do much to break up and improve the texture of the soil lying below the reach of the plow: as the roots rapidly decay, the effect is immediate.

5. It cannot be equalled for pasture. It will not only stand more close pasturing but it does not bloat sheep and cattle as do the other Clovers and Alfalfa. And an acre of Sweet Clover will carry as much stock as 5 acres of blue grass.

6. It will give a better and greater hay crop on the majority of farms than any other crop you can raise. of Alfalfa.

8. It is the most valuable green manure crop you can grow.

9. The roots decay very rapidly after being plowed up and add a large amount of plant food to the soil.

10. It has more uses than probably any other Clover grown. 11. As a food for bees it has no equal. It has been grown for this purpose for a great many years, particularly in the Southern tates.

12. It is gradually becoming recognized as the great American legume and is gaining recognition in all parts of the Country. either for hay, pasture, or as an ensilage crop.

14. There is no greater crop that can be grown for hogs or young pigs.

15. It will thrive on one-half the rainfall necessary for other legumes.

16. Sweet Clover is useful not only for reclaiming run-down farms. but for new and undeveloped lands.

Sweet Clover is an erect biennial plant with woody stems, the first season growing $11 / 2$ to 3 feet high and developing a large root, in which is stored food material for the second season's growth. The growth the second season usually reaches a height of 4 to 7 feet. It bears flowers and seed the second season and then the plant dies, so it is readily controlled by cutting before it goes to seed, which will prevent any seed being self sown.

The young growth of Sweet Clover is very succulent resembling Alfalfa but it is more stemmy and has a strong fragrant odor.

\section{USES.}

On hillsides that wash badly, Sweet Clover is very valuable, as the great roots push down and help hold the soil in place. Sometimes it is difficult to establish it on bare,

Adds Humus to Soil.-Many soils are lacking in humus or "regetable matter. Humus tends to make soils black and gives them the "rich" appearance of fertile garden earth. Humus makes soils mellow and lightens heavy soils, as well as increasing the ability of soils to hold water. The roots
of Sweet Clover are so large that they supply considerable humus to the soil but if much is wanted it would be well to plow under some of the top growth, but if much is wanted it would be well to plow under some of the top growth,
too. Whenever any heavy growth is plowed under for a green manure, it usually requires several months for this to decay and settle enough to make
the soil right for the following crop. Some growers report extra large yields of corn and other crops following Sweet Clover.

The Kansas Experiment Station writes that "Sweet Clover is a good crop to grow in a rotation, as it leaves the land in fully as good condition for succeeding crops as does Alfalfa.

The Montana Experiment Station says that this plant "seems to grow on stronger alkali ground than most other plants, and has considerable value as a reclamation crop on such ground."

Hay and Pasture.-From many states rome glowing reports of the value of Sweet Clover for hay and pasture. After acouiring the taste, stock often prefer it to other pasture. A farmer near Minneapolis experiences great difficulty in keeping his cattle away from it, as they frequently break down the fence to feed upon the tender growth before it is ready to cut.

It is usually possible to get one cutting of Sweet Clover the first vear and two good hay crops the second; or hay and pasture, or one hay crop and one seed crop. It is a splendid feed, about equal to Alfalfa.

Where used for hay, it is best to have the field free from timothy or other grasses which would smother the lower eye sprouts. It grows from erown shoots like Alfalfa the first year. The first-year growth should be cut close to the ground just as soon as the crown shoots begin to show. The secondyear growth comes from eyes or buds on the base of the old plant, not from
crown shoots. So cut the first hay crop when the Clover is 22 or 23 inches tall, regardless of bloom. Set the cutter-bar to leave 4 or 5 inches stubble.

Rake quite green and put in small cocks. Second cutting should be made when the growth is about 23 inches and just beginning to show bloom. The second cutting cures auicker than the first, but does not shed water so well. Handle so as to save the leaves.

Seed.-Sweet Clover produces seed abundantly-sometimes yielding five $60-1 \mathrm{~b}$. bushels or more of hulled seed per acre. The seed is produced by the second season's growth, but if the crop is left in possession of the field for several years, a crop of seed may be harvested each year. The largest seed crop is produced from the first cutting of the season, but a fair seed crop may be

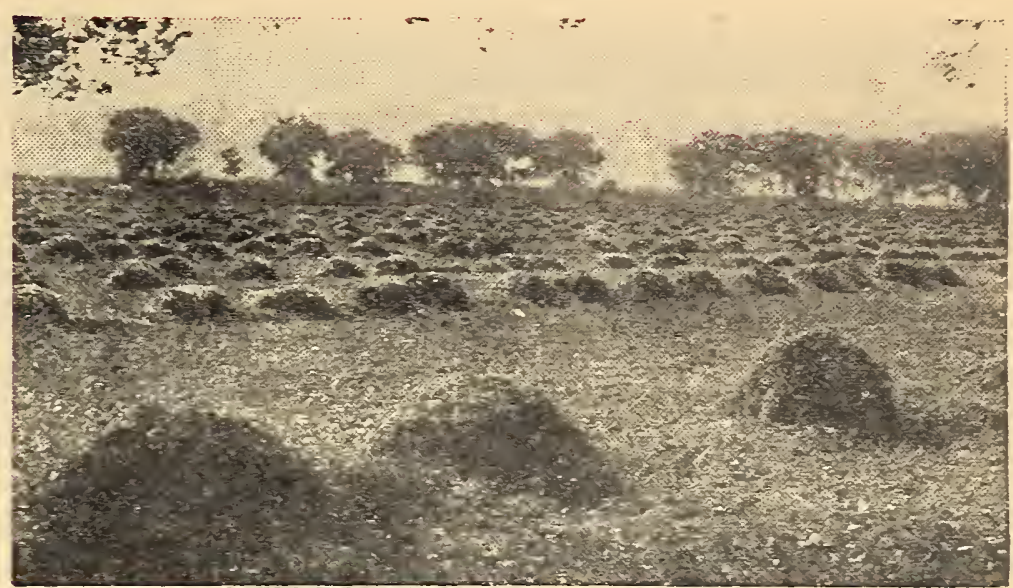

Field of Sweet Clover

secured from the second cutting, especially if the first crop is cut rather early for hay and several inches above the ground.

iven a seed crop is harvested enough seed usually shatters and falls to

Bee Pasture.-Sweet Clover makes splendid bee pasture, as it blossoms for many weeks during the second year of its growth.

\section{HOW AND WHERE TO SOW.}

Sow the seed at the rate of 15 to $20 \mathrm{lbs}$. per acre, with a nurse crop of grain, or alone, in well prepared fields in April or May. Cover the seed very lighly. It may follow a cultivated crop by preparing the seed bed with surfacebefore seeding. Sweet Clover requires a very firm, compact soil.

It can also be grown on pasture or rough land by sowing on the surface in early spring when the ground is honey-combed with frost. Sowing on

Sweet Clover is a legume having the same bacteria on its roots that grow
Swates on Alfalfa. Consequently it supplies nitrogen to the soil and prepares the way for Alfalfa.

Most authorities advise inoculating Sweet Clover just as you would Alfalfa, by treating the seed with Humogerm. By this method one can be sure of having plenty of the nitrogen germs in the soil, which will tend to give unnecessary.

Where to Plant.-Sweet Clover is especially valuable for building up Worn-out soils. It is not usually advisable to plant it where Red Clover or
Alfalfa flourishes, as these crops are commonly more valuable to the grower However, some farmers are planting Sweet Clover in preference to other crop for pasture.

It grows in a variety of soils-heary, light, wet or dry, almost anywhere. except in acid soil. But it does best on a firm, well drained soil which is richs in ime and delights in exposed subsoils and stony situations.

This plant frequently grows vigorously on lands too light to be adapted to the common farm crops; also on clay embankments from which the soil has been removed.

The Montana Experiment Station recommends it for improving Alkali
soils. It is a splendid green manure crop for plowing under as it supplies so much humus and nitrogen to the soil. Growers report extra large yialds of corn and other crops following Sweet Clover.

\section{SCARIFIED SEED ONLY SHOULD BE USED.}

Our best scarified seed often costs less than common grades offered by very high for germination. The germination on some lots is increased 50 to 60 per cent. You sannot fully appreciate the great advantage of scarified seed
unless you fully understand that Sweet Clover Seed has a hard coating and that 30,40 or even 75 per cent is known as hard seed and cannot grow promptly owing to this condition. In various tests, hard seeds have been planted under ideal conditions for germination for months and years without growing. Numerous tests conducted by botanists and agronomists of the U. S. show that the and they will germinate after several weeks, months, or years, but not in time to be of any practical ralue should never be used that is not scarified, as this treat-
Sweet Clover she
ment scratches the coating, increasing the germination, so that a stand is

\section{White Bloss om (mejlotus alba-}

The variety most commonly found and the one in greatest demand. All we have said in regard to Sweet Clover has reference to the White Blossom. It much in demand. The Thite Blossom Sweet Clover is destined to become the much in demand. The White Blossom Sweet Clover is destined to become the
most important of the legumes and will add millions to the wealth of the farmers
of this country.

Be sure and take up the question of Sweet Clover with us in buying you spring requirements of seed, for a few acres in Sweet Clover will certainly
make you more money than any crop you could grow. 


\section{Alfalfa-A Crop of Untold Value}

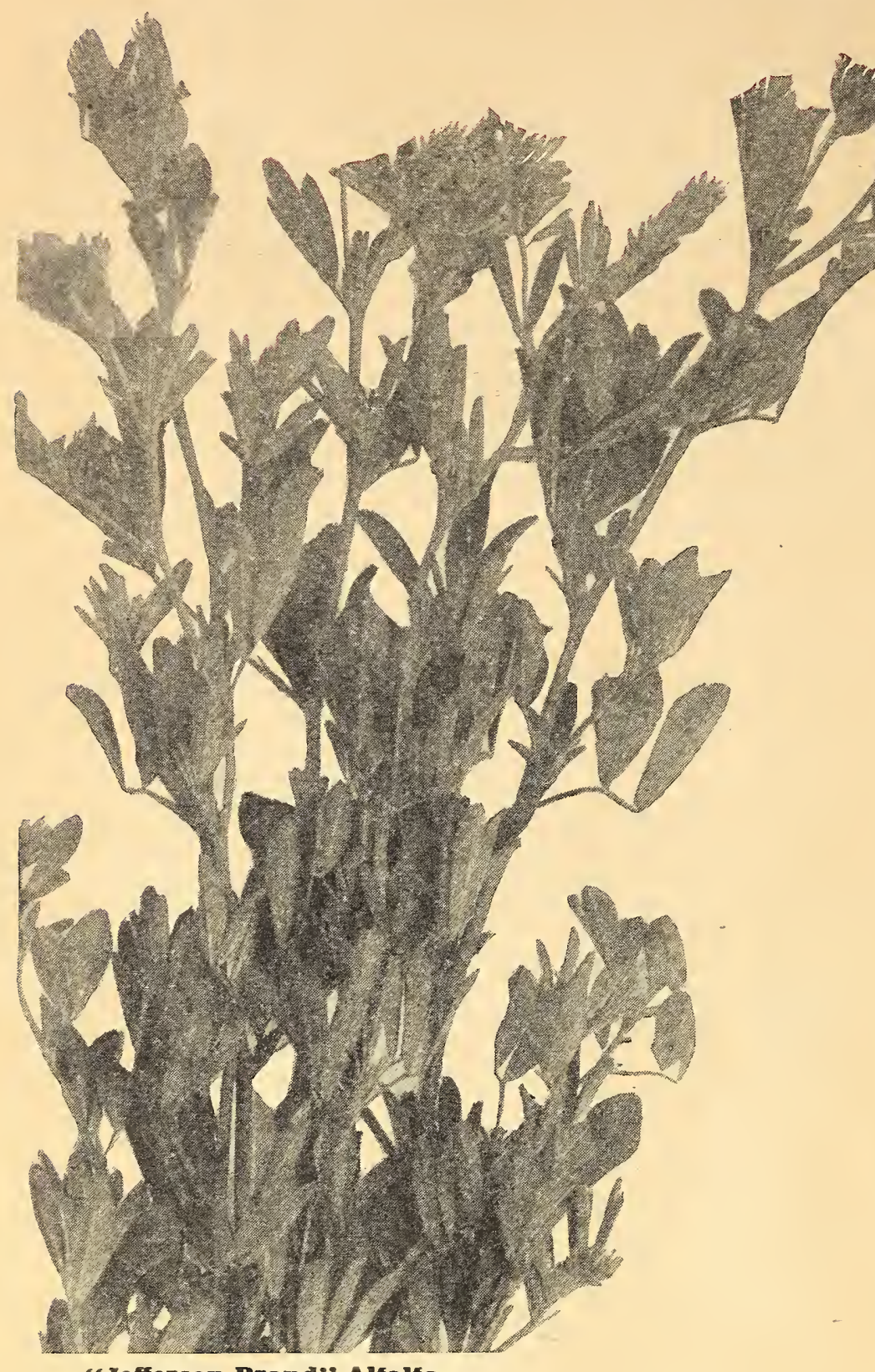

"Jefferson Brand" Alfalfa

GROW THE GREAT MONEY CROP

Don't miss the opportunity to produce two tons of high priced feed stuff where only one grew before. While Alfalfa growing is only in its infancy in the Northern and Eastern States, the farmers are beginning to appreciate the wonderful possibilities of this great crop, as indicated by the enormous increase in sales of Recleaned Alfalfa Seed, showing that Alfalfa is being sown in the North and East upon the most prosperous farms in those sections.

Get in line, get some of the seed of this great revenue producer. Don't let your neighbor grow better and bigger crops than you do simply because he grows this great legume, and after harvesting twice as much hay per acre as he could from any other crop he has his land in such a state of productivity that he can grow twice the number of bushels per acre that you can.

Be progressive. This is the age of brains; don't try to squeeze out a bare existence by plodding along the same old rut year after year. Take advantage
of the possibilities of doubling your income by growing this great money crop.

\section{SUCCESS WITH ALFALFA DEPENDS TO A GREAT EXTENT UPON THE GROWER}

Alfalfa is an easy crop to grow if proper precautions are taken, but it is absolutely necessary to sow only the best seed obtainable to secure the best results in growing Alfalfa. The reason for this is, no one should use seed from a more temperate climate than that in which he wishes to grow his crop, for no one feature is so essential as to secure good, hardy seed stock. Alfalfa is no longer an experiment; it is a reality. But still numerous farmers persist in experimenting with it-that is, they try to grow it by using a cheap grade of seed, by not preparing the seed bed, by not inoculating, and by sowing it upon sour soil without the use of limestone; and any one of the four mentioned conditions is enough to keep one from securing a stand of Alfalfa. While as a matter of fact, Alfalfa can be grown in every state in the Union, and in 99 per cent of the counties, and on 99 per cent of the farms. This is not a "wildcat" statement but a truth based on actual statistics, so do not hesitate about attempting to grow this great crop, because someone in the neighborhood has tried and failed, for you cannot afford to be without it upon your farm. It will be worth double to you what any other crop has been that you have grown, and we will venture the assertion that if you will follow the simple directions
set forth in this Guide for securing a stand that you will not be disappointed.

\section{FACTS ABOUT ALFALFA}

"There is no state in the Union in which Alfalfa cannot be successfully grown."

Alfalfa is more valuable than clover in many sections of the country, since wherever it flourishes it yields more per acre 列

Alfalfa produces from 3 to 7 tons of hay to the acre.

It has as much protein as Wheat bran.

360 stalks have been grown from one seed.

It does not exhaust the soil; it enriches the soil.

It will grow 3 to 5 crops a year.

Alfalfa in money value is worth 45 per cent more than other Clovers and 60 per cent more than Timothy.

Ten milch cows can be fed on less than 2 acres by soiling.

One acre will pasture 20 pigs for 6 months.

Three pounds a day makes a full feed for fattening lambs.

Four to five pounds makes a full feed for fattening aged sheep.

Thirty-five pounds makes full feed for fattening steers.
Sheep fed on Alfalfa will gain from 8 to 15 pounds in 75 days and will double with small grain ration added.

Lambs wintered on Alfalfa will produce one to two pounds more of wool than when on the anch.

Fed to dairy cows Alfalfa maintains the flow of milk equal to June Grass. It can be chopped fine with corn meal. Such a mixture is worth more a pound than the original corn meal.

Many interesting facts in addition to the above might be cited about Alfalfa. It would hardly be possible to say too much about Alfalfa, it is a working plant which is changing the destiny of many farming sections.

"Its long, branching roots penetrate far down, push and crowd the earth this way and that, and thus constitute a gigantic subsoiler. These become an immense magazine of fertility. As soon as cut, they begin to decay and liberate the vast reservoir of fertilizing matter below the plow, to be drawn upon by the

Probably no other crop in the history of the nation has been the means of extending agricultural development over as wide an area or to as great an extent as Alfalfa. From the arid West to the humid sections of the Corn Belt, it is making it possible to grow upon the farm a greater number of cattle, hogs,
horses and sheep than was ever possible before Alfalfa entered the realm of horses and sheep than

\section{GROWING THE CROP}

Soil.-Alfalfa is very particular about the soil required for its best development; in fact, more failures in securing a stand can be attributed to not paying attention to the requirements necessary in placing the soil in condition to grow Alfalfa than upon any other one thing. The soil for the production of Alfalfa must be well drained. Good drainage and ground limestone, together with proper inoculation and pure seed, seem to be the chief prerequisites for successful Alfalfa culture.

Preparation of the Seed Bed.-The seed bed in this section should be plowed as early as possible for fall sowing, or better yet, summer fallowed; it should be worked into a fine state of cultivation and should be well settled. More Alfalfa each year is seeded in the spring, sowing it with a nurse crop the same as Clover.

Seed and Seeding.-Get good, pure, unadulterated seed. It is not only necessary that the seed should be strong in germinating qualities but should be free from noxious weeds, and be of a variety the seed stock of which is grow'n in such a locality as it will meet the requirements of the section in which you wish to grow the crop. The seed should also be inoculated in order to secure a strong, vigorous growth of young plants, and although Alfalfa will (Continued on next page.)

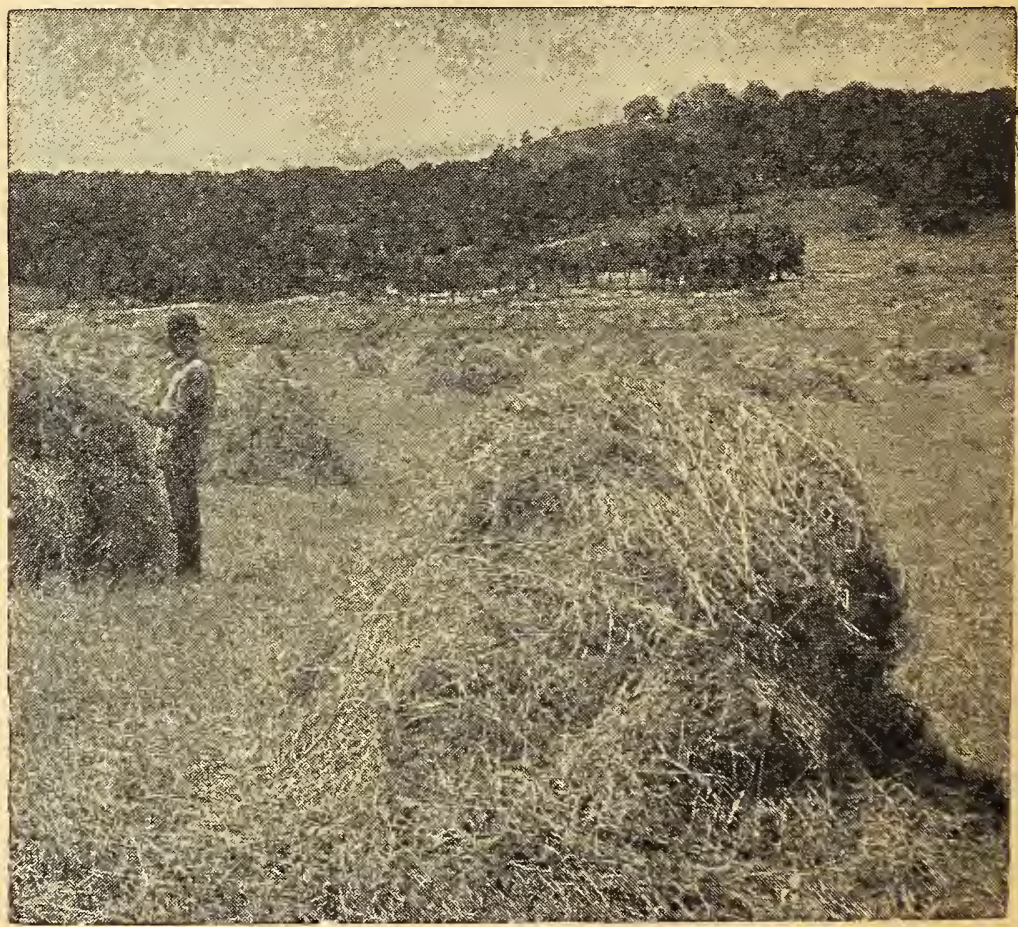

Field of "Jefierson Brand" Alf alfa 


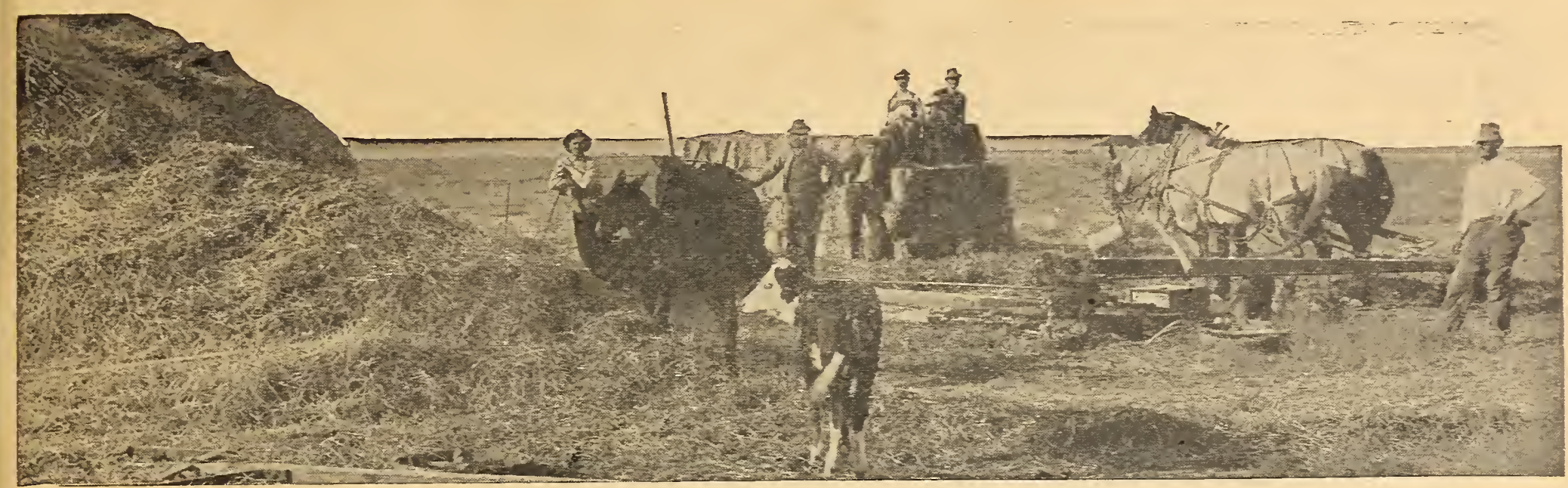

Baling a Bumper Crop of "Jefferson Brand" Alfalfa

\section{ALFALFA-Continued}

thrive in many sections without inoculation, the extra gronth secured from inocluation always many times more than repays one for the exira cost. It should be sown at the rate of from 12 to 15 pounds per acre. The time depends upon the latitude, season and condition of the land. In some sections it is sown as early as March, but more is sown in April and May.

Inoculation is Necessary.-Inoculation means putting or planting in the soil nitrogen-fixing germs or bacteria, without which the Alfalfa cannot flourish. Where Sweet Clover grows wild, in the field or along the roadside, artificial inoculation for Alfalfa may not be necessary as the same germs grow on the inoculation for Alfalfa may not be necessary as the same germs grow on the Sweet lover as on Alfalla and natural inoculation takes place. But there is no other plant which commonly grows wild in the North that can support
the same germs as the Alfalfa. All the legumes, including clover, peas and beans. bear bacteria, but a special kind lives on each plant.

These germs on the Alfalfa roots from nodules from the size of a pin head to a pea.

There are several methods of inoculating Alfalfa seed, butwe recommend the use of Humogerm as priced on the bottom of page 10.

Harvesting.-The time of harvesting will depend upon whether the crop is to be cut for hay or seed. In cutting the Alfalfa for hay the best time to start the mower is just as the young shoots of the second crop are commencing to start.

\section{Hardy "Jefferson Brand" Alfalfa}

Extremely valuable for all sections where Alfalfa is grown. This seed was produced from fields that have stood there thirty years, living through ice sheets and temperatures of 30 degrees below zero in winter and hot, dry wind in summer. This seed is bound to produce strong, vigorous plants. This is by far the best strain of common. Alfalfa and the seed we are offering you is very pure, absolutely free from thistle, dodders and other noxious reeds.

\section{Grimm Alfalfa}

The much advertised Grimm Alfalfa is truly a wonderful acquisition to the Northern farmer. Originated in Minnesota by Wendelin Grimm man years ago-selected from the hardiest plants year after year until it is a fixed type of extreme vigor. The crown of the plant is receding, so is protected by the surface of the soil and is very heavily stooling, one root often producing 300 to 400 shoots. Roots are fibrous and branching, instead of the long tap root. A variety especially adapted for shallow soil in cold regions. The flowers are variegated-purple predominating. Some growers report larger yields of Grimm than other strains, giving a leafier, finer hay. Our seed is guaranteed genuine.

\section{New Crop Iowa Timothy Seed (1.1.15 Las, pre a c are)}

Timothy is the best known, most extensively sown and one of the most profitable grasses grown in this country. Having a large bulk of stems, with few leaves, the hay wastes little in transportation. The grass stands up well, the hay is easily cured and heavy for its bulk. Timothy is very easily estabthe hay is easily cured and heavy for its bulk. Timothy is very easily estabyields its best crop the year after sowing. It is extremely hardy, enduring extremes of heat and cold. It does best on moist clay soils.

Timothy rapidly exhausts the soil nitrogen and so the meadows are greatly improved by a dressing of stable manure or other fertilizer. The latter should contain a large amount of nitrogen. Clovers grow well with Timothy and aid it by supplying nitrogen. Medium Red Clover makes a good combination with it and together they form the standard crop for mowing and pasture lands on the majority of farms in the northern and middle states. For a misture of Timothy and Alsike Clover see next page.

We are situated next door to the greatest Timothy seed producing section in the world and are in constant touch with the crop conditions and personally in the world and are in constant touch with the crop conditions and personally acquainted with a large number of growers and dealers, so owing to our favorit comes to offering Timothy seed either direct to the farmer in bushel lots or to the large wholesale dealers in car-lots.

There was an extremely short crop of Timothy seed this year and never before was there such a mad scramble among the buyers at harvest time Some buyers actually paid more for the seed in the rough than they can expect to get for it after recleaning. Mr. Mackey took personal charge of our buying operations and both he and $\mathrm{Mr}$. Gorton spent several weeks in the fields at harvest time. A great many cars of seed were bought. many cars of seed were bought. regular trade and the balance im. mediately cleaned and put on the mark seed is the choice seed from all that was bought, and, due to careful buying, it cost us no more than most buyers paid for the poorest seed. It has been cleaned and re ing plant and we take great pride in being able to furnish our customin being able to furnish our customers with strictly new crop seed of exceptionally high purity at prices present market.

For prices on all field and grass seeds, see your dealer or write us direct for samples and current price list. 


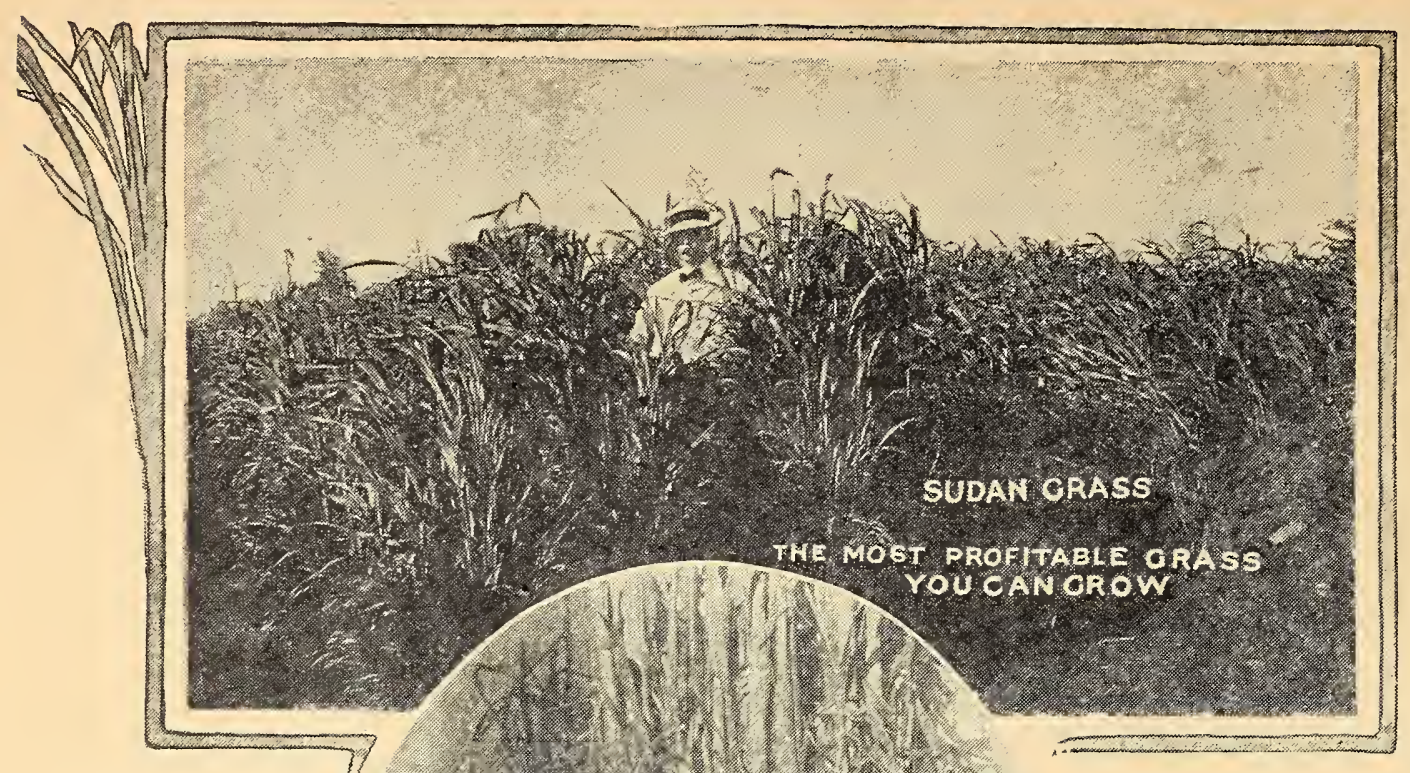

On our own farms we grow the choicest, rye. The worthwhile varieties are to known to the farmer of today to need description. Prices of the various varieties we grow are given on our Current Price List.

These prices are for the finest re-cleaned pedigreed stocks, samples of which will be gladly sent for the asking. You will be surprised at the exceptionally fine appearance of the seed, large, plump, berries absolutely pure, all grown far enough north to be hardy and resistant.

let us figure on it.

\section{Bromus Inermis}

This wonderful hay and pasture crop is meeting with universal favor wherever grown. It is one of these crops that can be grown on any soil and under the most adverse conditions. Especially adapted to the dry, cool sections of the Northwest. It has been the means of converting thousands of acres of barren waste into a land of beauty and profit. It withstands the adverse conditions of climate and rainfall from year to year, and to secure a stand of this luxuriant grass once is to never be without plenty of hay and pasture. This is the crop that never fails, and if you are growing grasses
proten under dry land conditions, you should certainly not be without this wonderjul crop.

\section{Orchard Grass}

(20-25 LBS. PER ACRE)

Nore Strong Root Growth

\section{Alsike Clover and Timo= thy Mixed (20.15 LRs. pre acres)}

Where Alsike Clover and Timothy are grown together, and the seed is saved therefrom, it is impossible, in cleaning, to make a complete separation of the two.

On this account we purchase the seed for less money and we can sell it for less than would be the case if a perfect separation could be made.

Those desiring to sow Alsike and Timothy together can save considerable money by buying the seed of these two varieties together as originally harvested. The Minnesota Experiment Station recommends using Alsike in all Timothy and Medium Red Clover mixtures. The Alsike tends to increase the forage crop and in addition will replace the Red Clover as the latter begins to die out, since the Alsike is a hardy perennial and does not easily winter-kill. Alsike and Timothy hay is much richer in feeding value than Timothy alone and will flourish on soils too moist for clover. Alsike is suitable for either hay or pasture. It is finer and more leafy than Medium Red Clover and cattle prefer it. Sow 12 to 15 pounds of the mixture per acre.

Let us submit samples and prices for your consideration.

\section{Red Top (6.8 LBв. PER ACRE)}

As a hay crop, Red Top is next to Timothy in importance among grasses in this country. It grows two feet or more high and yields one to two tons per acre. It increases in thickness for several years after sowing and is one of the most permanent of cultivated grasses.

The place for Red Top is on rather moist soil, deficient in lime and fertility. It will grow where the soil is too poor for Timothy and Kentucky Blue Grass. It is a good variety to sow with Timothy and Clover for meadow or pasture and is more permanent than either of the other two. It should be fed close, for if it is allowed to grow up to seed, the cattle dislike it. On good soil it grows about two feet high; on poor, gravelly land about half that height. It has been grown successfully even on alkali land where other grasses failed.
Red Top, commonly known as Herd's Grass, should be extensively grown, especially with other grasses.

\section{Kentucky Blue Grass}

The most widely known of all natural grasses, which does well everywhere and can be found in almost every part of our broad country. It is grown more for pasture than for hay, as it starts to grow unusually early in spring and provides good feed in May and June in our Northern States, and produces a good growth until the ground freezes. This grass is very hardy and neither injured It is suited to any variety of soil, but seems to succeed best on moist, rich land. Used extensively for lawns.

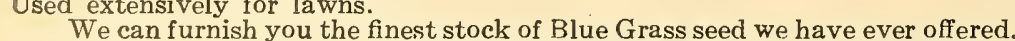
The fields stripped were well ripened and very heavy quality of the finest grade of seed. You will find our seed strictly fancy stock, being very heavy in weight weighing from 21 to 23 pounds to the measured bushel, and unusually brigh in color. Our seed is not discolored but is sweet bright stock of extra high
germination, and is guaranteed to grow, which is an important matter to consider.

A most valuable grass for pasture and hay land and on account of its earliness very valuable for permanent pasture, as it furnishes the first green bite in the spring and the last in the fall, is quick to recover from close cropping and even thrives better the more it is cropped. Gives rich pastures till late in the fall. It will stand the drought, well suited for shady places, such as orchards and groves. Richer feed than Timothy and outlives it

\section{Meadow Fescue or English Blue Grass ${ }_{\mathrm{PER} A C \mathrm{CRE})}^{(24 \mathrm{LBS})}$}

(Festuca Pratensis.) Especially suited for permanent pasture and is also fine for hay. Grows two to three feet high but not in tufts like Orchard Grass. The hay is very nutritious and cattle thrive on it whether it is dry or green. Succeeds even in poor soil, and as the roots penetrate deep, from 12 to 15 inches, it takes extremely dry weather to affect it. As a fertilizer it has valuable properties. It will endure severe freezing and its use is becoming more widespread each year.

\section{Perehnial Rye Grass}

Used exclusively for pastures and lawns; succeeds well in shady places. Has given excellent satisfaction wherever tried. Especially adapted for pastures, as it will endure closé cropping. It is of strong and quick successive aftergrowth. Perennial or English Rye Grass produces an abundance of foliage, which remains bright and green throughout the season.

\section{Sudan Grass (16:20 rBs. per a ARRE)}

It Laughs at Droughts and Rejoices When it Rains

Sudan Grass has proved itself to be one of the surest hay crops for the Middle West. It does well when it gets plenty of rain but it is when the drought comes that it shows its real worth.

Sudan Grass is an annual and like Millet must be planted each season. It grows very tall, reaching a height of seven to eight feet. The stems are very small, rarely thicker than a lead pencil, and the plants stool wonderfully, producing under favorable conditions as many as 100 stalks from a single seed.

Under favorable conditions it will make three cuttings and yield up to six tons of hay per acre.

Sudan hay is much relished by horses and cattle, and they will leave almost any kind of roughage for it, cleaning up heads, blades and stalks.

Sudan Grass is generally broadcasted, using from 15 to 20 pounds per acre. It is important that the seed should not be planted until the soil has beeome warm, as cold soil only delays germination and dwarfs the early growth. It can be planted any time during the summer as a catch crop, so long as seventy to eighty days intervene before the date of the first expected frost. 


\section{"Billion Dollar Grass"}

(10-15 LBS. PER ACRE)

Especially Valuable for Silo and for Feeding Green-Better Than the Best Corn Fodder.

From Japan, that mysterious country, which is furnishing (and has furni shed in the past) many rare farm seeds, comes this remarkable grass-remarkable in a hundred different ways, for there is nothing known to man today that is more luxuriant, more prolific, more marvelously rich and vigorous in growth than Billion Dollar Grass.

It grows from 6 to 9 feet high, stands up remarkably and yields enormous crops. When cured it makes good hay and in quality is superior to corn fodder. It is relished by all kinds of stock. It may be sown broadcast at the rate of 15 pounds an acre, but it is better to sow in drills 12 to 18 inches apart, using 10 to 12 pounds to the acre. Cultivate until the plant is 18 inches high, when ils ravia groverth wil smother all weads.

\section{German or Golden Millet \\ 50 POUNDS PER ACRE}

In our opinion, one of the very best of millets. It is far superior to common millet both in quality and yield. Much of the German millet seed sold on the market is not pure but is mixed or common seed. Our seed is as pure stock as we could obtain

German millet grows taller, firmer and more leaves than common. On good soil it grows to the height of from 4 to 5 feet and ought to make a vield of from 4 to 5 tons of splendid hay per acre. If properly handled, you are sure of an uncommon yield of either hay or grain.

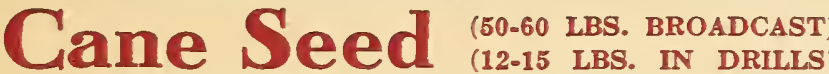

Cane is recognized as the leader of forage plants. Growing cane for ensilage has become an established part of American Agriculture. The acreage sown to cane is greatly on the increase. A farmer who has sown cane an harvested the wonderful hay crop can not see how he can be without it. The yield is so much greater that a few acres of cane is equal to a big field of timothy. If you have timothy hay sell it and sow cane for your feed and you will be many dollars ahead. Cane is far superior as a feed; stock of all kind relish cane hay and fatten on it.

Early Amber is considered the best variety and this is the one we recommend. It is more generally grown and is early, making a splendid growth regardless of the time of seeding.

\section{Soy or Soja Beans}

The value of Soy Beans as a hay and forage crop is recognized more and more each year. Soy bean hay contains a high percentage of protein, is superio to clover hay and bran in feeding value, and as a milk and butter producer i equal to alfalfa hay. The beans and bean meal contain about $35 \%$ digestiole protein and stock eat them with relish and thrive on them. Hogs fed on soy beans in combination with corn fatten much more economically than on corn alone. A bushel of soy beans is worth at least two and a half times as much a a bushel of corn.

Soy Beans planted together with corn for ensilage make the best and cheapest balanced ration for milch cows and other livestock on account of their high protein contents. They will replace the expensive mill feed such as bran and shorts.

CULTURE-Soy Beans may be planted either broadcast or in drills. A better seed crop is harvested if sown in drills and cultivated. Sown in drills for cultivating it requires 30 to 40 pounds of seed per acre; in drills with corn, 10 to 15 pounds per acre, drilled like grain or broadcasted 60 to 90 pounds per acre. A crop of beans will leave the ground in a clean and better conINOCUI

Not only will you have the assurance of a better stand, boy Bean Bacteria. the succeeding crop will have the benefit of the nitrogen stored in crop and

BLACK EYEBROW (106-110 DAYS).-Beans are black and yellow, easily identified. Very prolific, early ripening and desirable. Produced the MANCHU (110-120 DAYS).-Medium size, clear yellow bean; grows upright, heavy foliage and splendid yielder. Our stock true to name, grown by ourselves, here in Iowa.

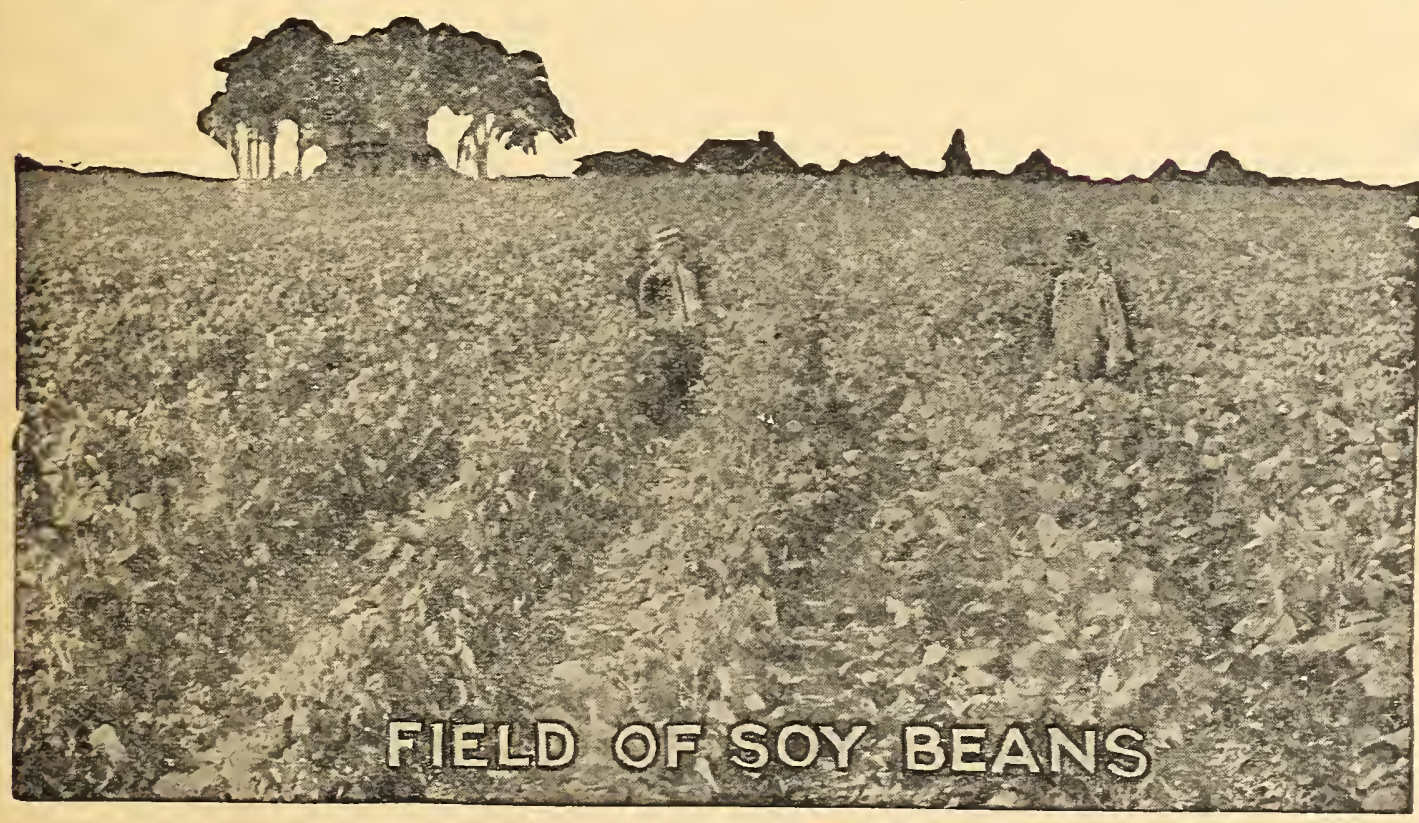

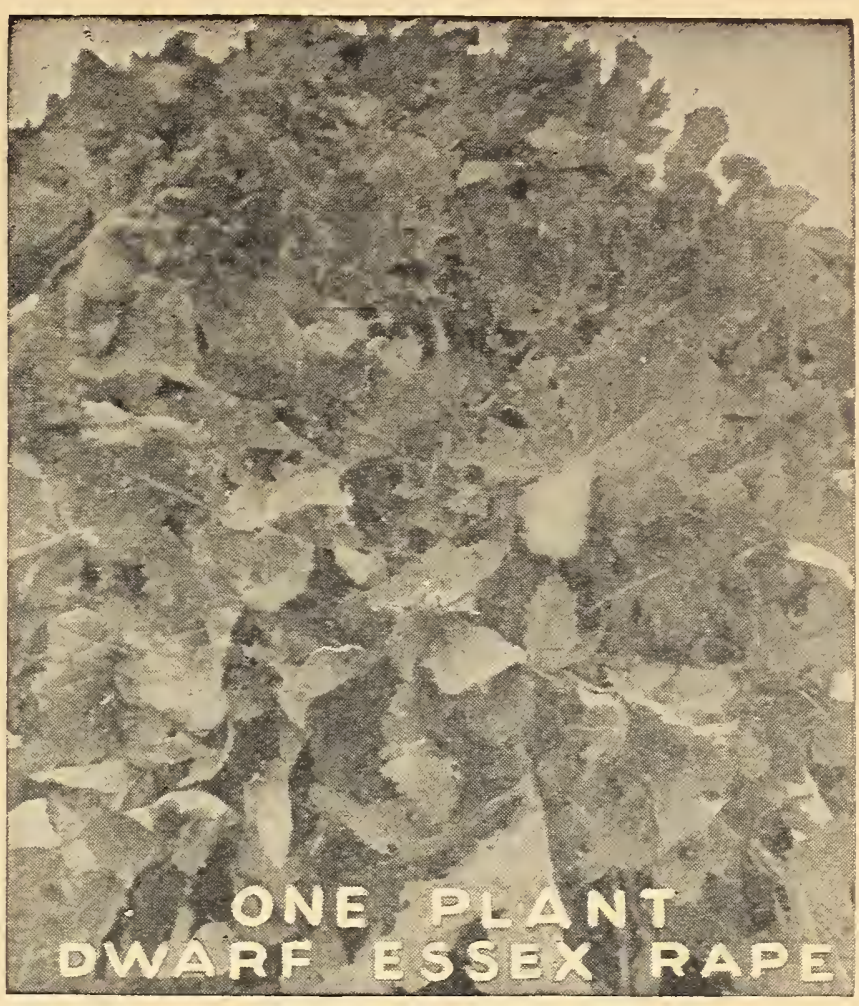

\section{Genuine Dwarf Essex Rape (4-6 LBS. PER ACRE)}

Valuable Feed for Cattle, Sheep and Hogs.

A forage plant of great merit, easily grown on any land that will raise turnips or corn, and will furnish abundant supplies of succulent, rich, nutritiou pasture at a season when it is most needed. Under ordinary favorable con-
ditions Rape is ready for pasturing sheep or hogs in about 6 weeks from date of sowing.

As a catch crop after small grain or just before corn is laid by, it is the greatest feed that man could provide for; in fact, it will yield more green feed for pasturing purposes than could be raised from any other crop at anything apthe same cost per acre.

Dwarf Essex Rape is not only valuable for pastures, but is most excellent for green manuring. There is no plant which will give so heavy a yield of forage at so small a cost as this.

to Resolve now to employ Genuine Dwarf Essex Rape, as it is the right thing to do. Sow liberal auantities along with other grain. It will surprise you to have after the grain is harvested, which is the very time you want it.

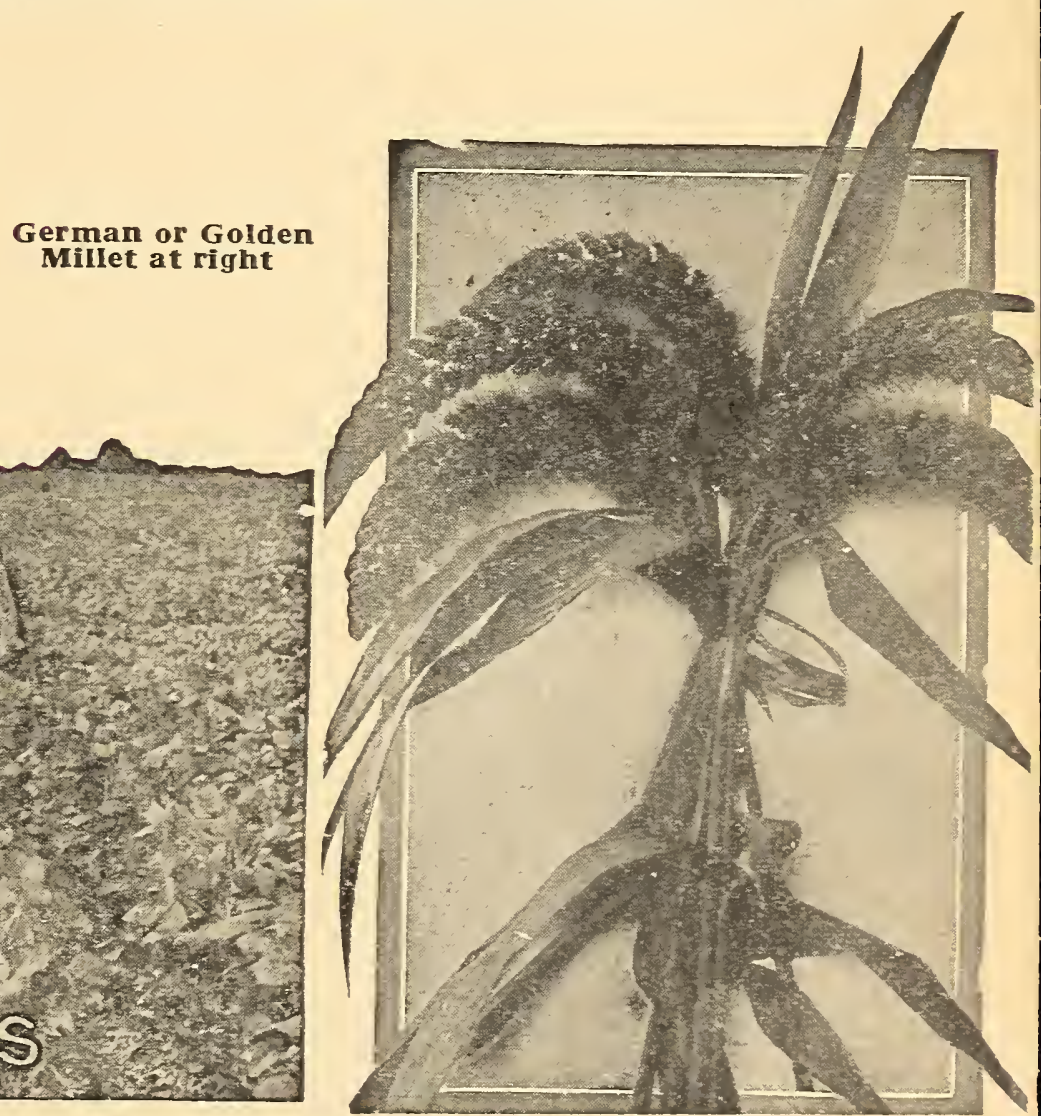




\section{Dependable wan Vegetable Seeds}

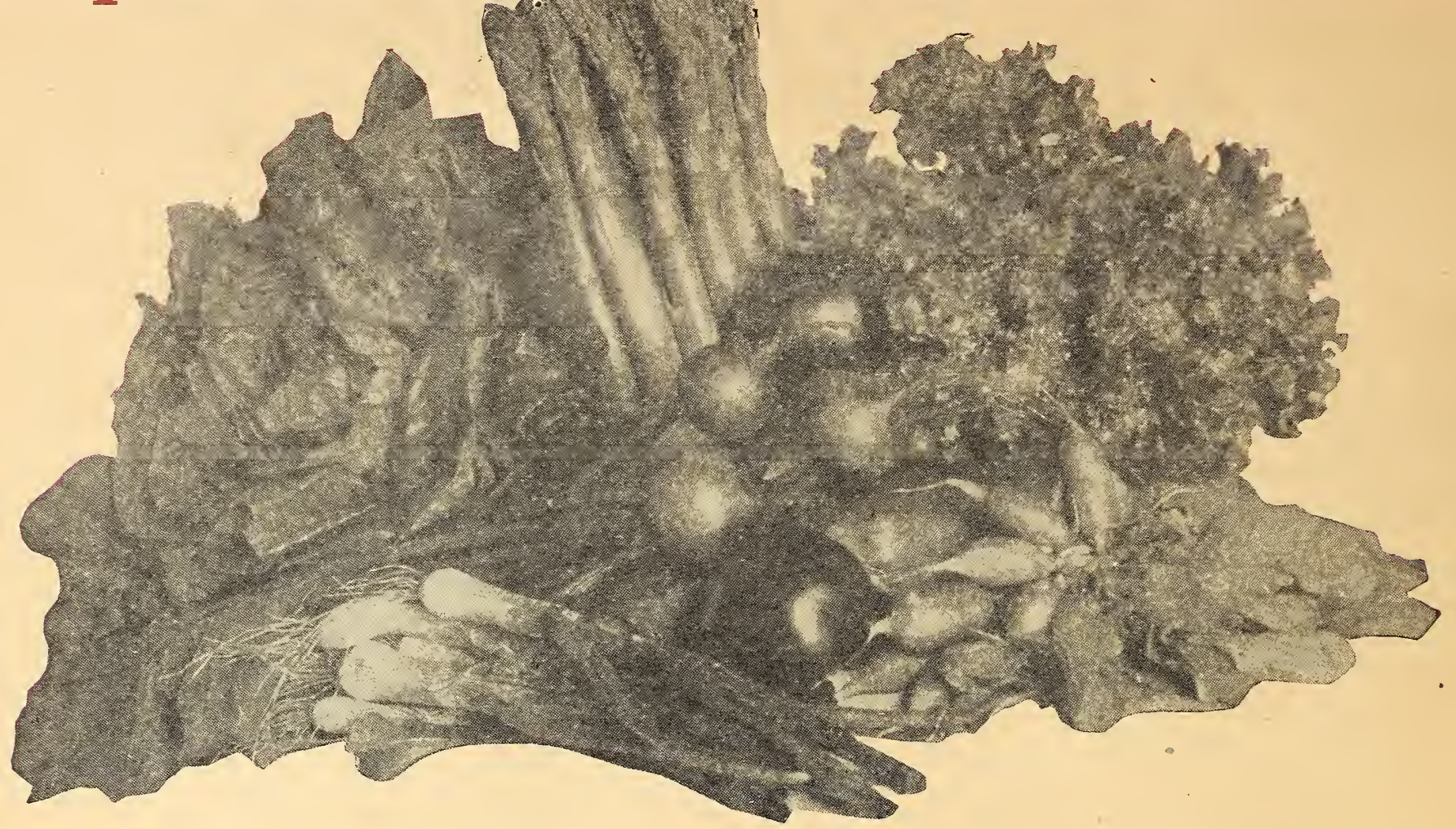

ET it be understood, please, that Jefferson Seeds for the Garden are not cheap "jobbing stocks." They are "Market Gardener's stocks," grown by us or for us under special contract by the best growers in the sections best suited to the growing of each particular vegetable business does show it.

\section{Do You Buy Seeds on Faith?}

Seeds, you know, especially Vegetable Seeds, are bought almost entirely on FAITH. Full and positive knowledge of vitality, trueness to name, degree of hardiness, resistancy to adverse conditions, and adaptability to given localities can only be had from actual acquaintance with parent stocks and growing conditions of the seed itself. If we wish to justify the FAITH you place in us when you give us your order we must know the seeds we sell, and we must justify this FAITH for our own protection, if nothing else.

\section{Good Seeds Our Protection}

Suppose we give you a "stinging" this year, either knowingly or unknow" ingly, causing you to have a poor crop or a complete failure. Would you buy from us again next year? You would not; neither would your neighbo who knows of the deal. How long would we exist under those conditions,
and what of the thousands of dollars invested in our business? We are staking the very life of the Jefferson Seed Houses upon the dependability of Jefierson Seeds.

\section{Let's Have the Truth}

We do not insult your intelligence by claiming to grow all our seeds ourselves. You know that there is no one place on earth where all vegetables and flowers can be grown successfully and that no one firm or individual en gaged in the general seed business does or can grow all the seeds they sell. How then, you may ask, do we know with a certainty that the seeds we sell are the best that can be grown?

\section{We Know the Seeds We Sell}

Forty long years we have been in the seed business. In that time we have formed a wide acquaintance among the specialists engaged in the growing of different seeds and have made some valuable growing connections. We have brought into our organization men who have had actual experience with the brought into our organization men who have had actual experience with the adjoining our plant are test plots where varietal tests are made. Then there is, of course, our laboratory, where careful purity and germination tests there is, of course, our laboratory, where careful purity and germination tests
are made of each and every lot of seed before it is sent out to our customers.

\section{Where They Are Grown}

You may be sure that in these 40 years we have learned where the best seeds are grown. We have learned, for instance, to have our Beans, Peas, Vine Seeds, Radishes, Onions, and Tomatoes grown in the north; to go to Europe for the best Cabbage, Cauliflower and Celery; while the Pacific Coast States may be depended upon for most Root Crops, and such seeds as Lettuce, Parsley, Spinach, etc. First profits from seeds of this quality are less than they would be on a cheaper grade of seeds for our selling prices are down with the cheap seed class. Gain in volume of business and number of satisfied customer each year more than pay for this seeming loss of profits, however, so our policy will continue to be the selling of the highest quality seeds at conservative prices.

\section{Renamed Varieties a Scandal to the Trade}

We have learned, too, what varieties are worth while and to avoid freaks, novelties, and renamed varieties. Renamed varieties are the scandal of the seed trade. One single variety may be offered under as many as 8 to 10 names, oftentimes under two or more names in the same catalog. In this book you will find a few varieties listed that are not listed by other seedsmen. These are strains which have been developed and grown either directly by us, or by our contract growers especially for us. We honestly believe them to be in a class by themselves or we would not list them and you positively will not find the same strains listed under more than the one name in this or any other catalog.

\section{Henry Ford Service}

Just a word concerning the service we give. We have mentioned before that service to customers was one of the hobbies of our Assistant Manager. The superintendent of the garden seed department is directly responsible to him, and, together, they have worked out an almost perfect system for the handling of orders. We doubt if the speed and accuracy of this department is excelled by any outside the marvelous efficiency systems of Henry Ford.

\section{Just What Does "Service" Mean?}

This word "service" is very much abused and overworked. For this reason we want to tell you what we mean by "service." We mean that, first, your order must be filled with the best possible quality of seeds; second, it must be filled promptly (inside of 48 hours from the time it is received), or you must be notified at once explaining the delay; third, the order must be ylled accurately so that you'll get exactly what you order; fourth it must be properly packed for shipping so that it will reach you in perfect condition if) properly packed for shipping so that it will reac

\section{Five Cent Packets}

You will notice that most all packets are listed at five cents. This is in line with our policy of furnishing highest quality seeds at lowest possible prices.

The packets are large and well filled, containing as much or more seed than any packet seed you can buy at either 5 or 10 cents. The quality is excelled by none, regardless of price. 


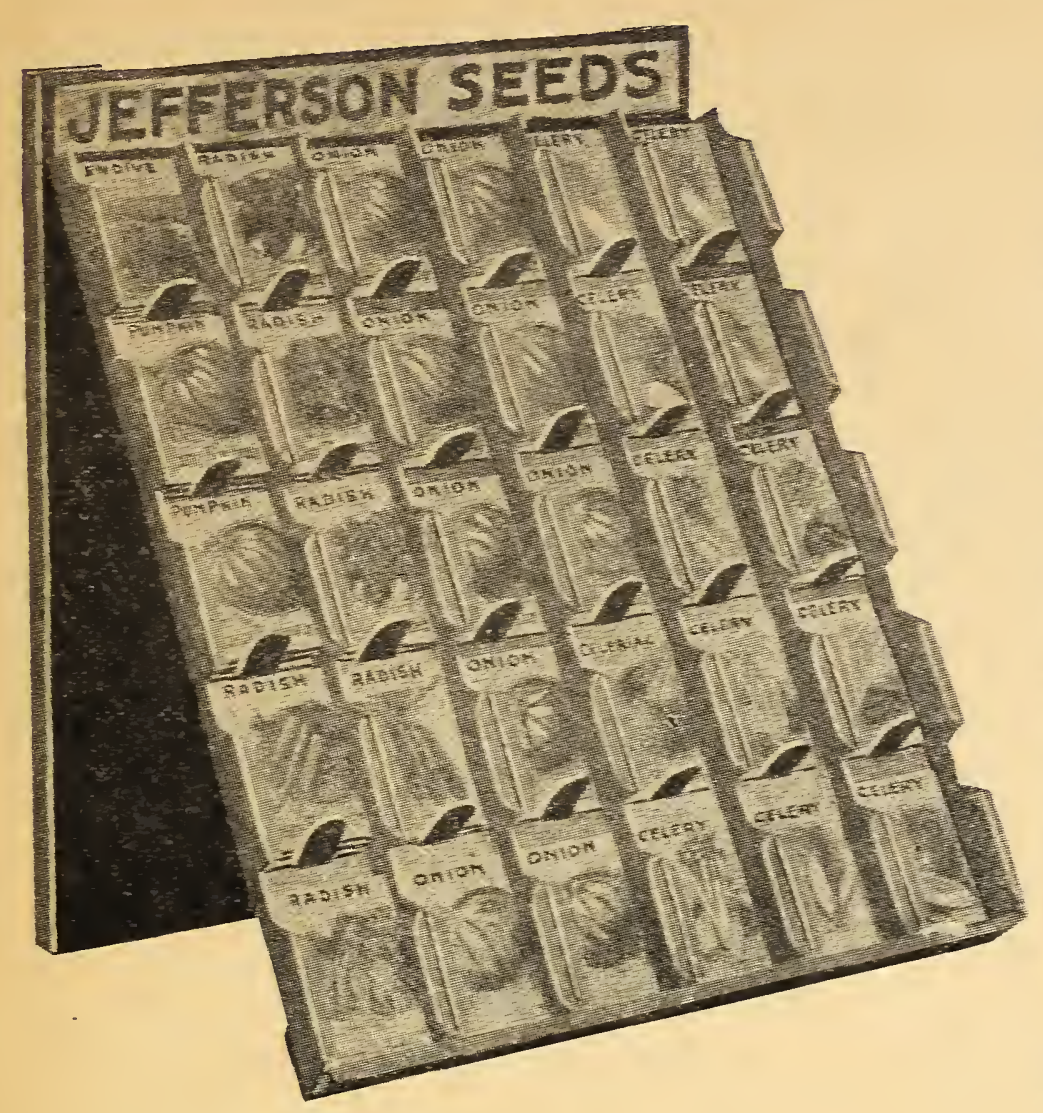

\section{ABOUT ORDERING}

In ordering seeds by mail there are a fer simple rules that the custome hould follow so that his o:der may be handled with greatest dispatch and obse-ve them when ordering. It will helo us both.

Prices auoted in catalog and price list state whethe: me poil, express, or freight. charges or not. On items that are not prepaid we will send by foight press unless you specify pareel post, in which ease you must include money to

(b) Always sign your name and be sure to write plainly your Post O Ice,
County, and State. If your freight or expess offce has a difierent name do not fail to give it also.

You can sead remittance by $P$.

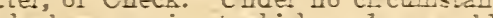
C. $D$. D of if (d) If for any reason whaterer rou are not enti-els satisfed bith rout arder when it reaches you, hrite us promptly. Wor en wh rou are in reporting erross or dissatisfaction, the sooner and better can pe male (e) Please remembe: that Jeñerson Brand Seeds are gromin and selected in the ground, therefore, Jefierson Seed Houses give no warranty, express or in plied, as to description, quality, productiveness or any other matte: of an for the crop, and every article named in this catalog will be executed on these are at once to be returned. This, in accordance pith the usual watranty every legitimate seed house in America.

\section{Parcel Post Table}

This table will aid you in making up your order from our "not prepaid" parcel Post unless ordered at postpaid prices or if money is not included to pay postage.

\section{DOES YOUR DEALER HANDLE JEFFERSON SEEDS?}

Jefierson Seeds are sold by many prominent dealers throughout Iowa and Missouri. Walk into their stores and the handsome Jefferson display case will not fail to catch your eye. In these cases you will find the better and more xidely known varieties-and so arranged in the case that it's easy for you to make your selections.

The quality is identical with what you would get if you sent us sour order direct. Our's are not commission seeds sent out to dealers to sell what (most of the better dealers prefer not to act as commission agents, but to oriz the stocks they sell). Old seeds that are left in the case at the end of the season are destroyed by our representatives when they make their annual calls and the following season new seeds are sent to take their place.

Our dealers always have pure, fresh seeds and are not returning old seeds to us to be blended in with new and sent out again and again until sold. If vour dealer does not handle our seeds, send us your order direct, then tell him of the excellent results you have with Jefierson Seeds. Ast him to write him of the excellent resul

\begin{tabular}{|c|c|c|c|}
\hline STATE & $\begin{array}{l}\text { Postago } \\
\text { per } 1 \mathrm{~b} .\end{array}$ & STATE & $\begin{array}{c}\text { Postage } \\
\text { Derlb. }\end{array}$ \\
\hline 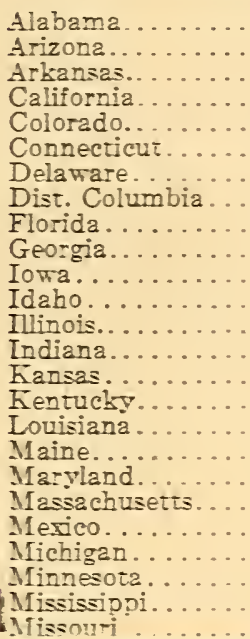 & $\begin{array}{r}5 \text { cents } \\
8 \text { cents } \\
1 \text { cents } \\
10 \text { cents } \\
6 \text { cents } \\
8 \text { cents } \\
6 \text { cents } \\
6 \text { cents } \\
8 \text { cents } \\
6 \text { cents } \\
1 \text { cent } \\
8 \text { cents } \\
1 \text { cents } \\
1 \text { cents } \\
4 \text { cents } \\
6 \text { cents } \\
6 \text { cents } \\
8 \text { cents } \\
6 \text { cents } \\
8 \text { cents } \\
12 \text { cents } \\
4 \text { cents } \\
1 \text { cents } \\
6 \text { cents } \\
4 \text { cents }\end{array}$ & 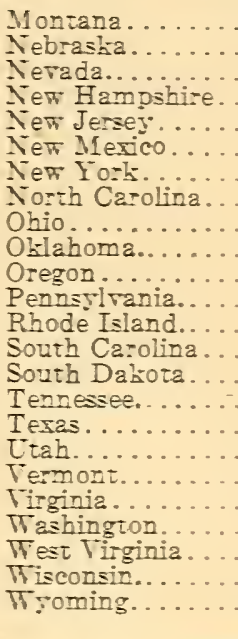 & $\begin{array}{l}8 \text { cents } \\
4 \text { cents } \\
8 \text { cents } \\
8 \text { cents } \\
8 \text { cents } \\
8 \text { cents } \\
8 \text { cents } \\
8 \text { cents } \\
6 \text { cents } \\
4 \text { cents } \\
10 \text { cents } \\
6 \text { cents } \\
8 \text { cents } \\
6 \text { cents } \\
1 \text { cents } \\
6 \text { cents } \\
8 \text { cents } \\
8 \text { cents } \\
8 \text { cents } \\
6 \text { cents } \\
10 \text { cents } \\
6 \text { cents } \\
1 \text { cnets } \\
6 \text { cents }\end{array}$ \\
\hline
\end{tabular}

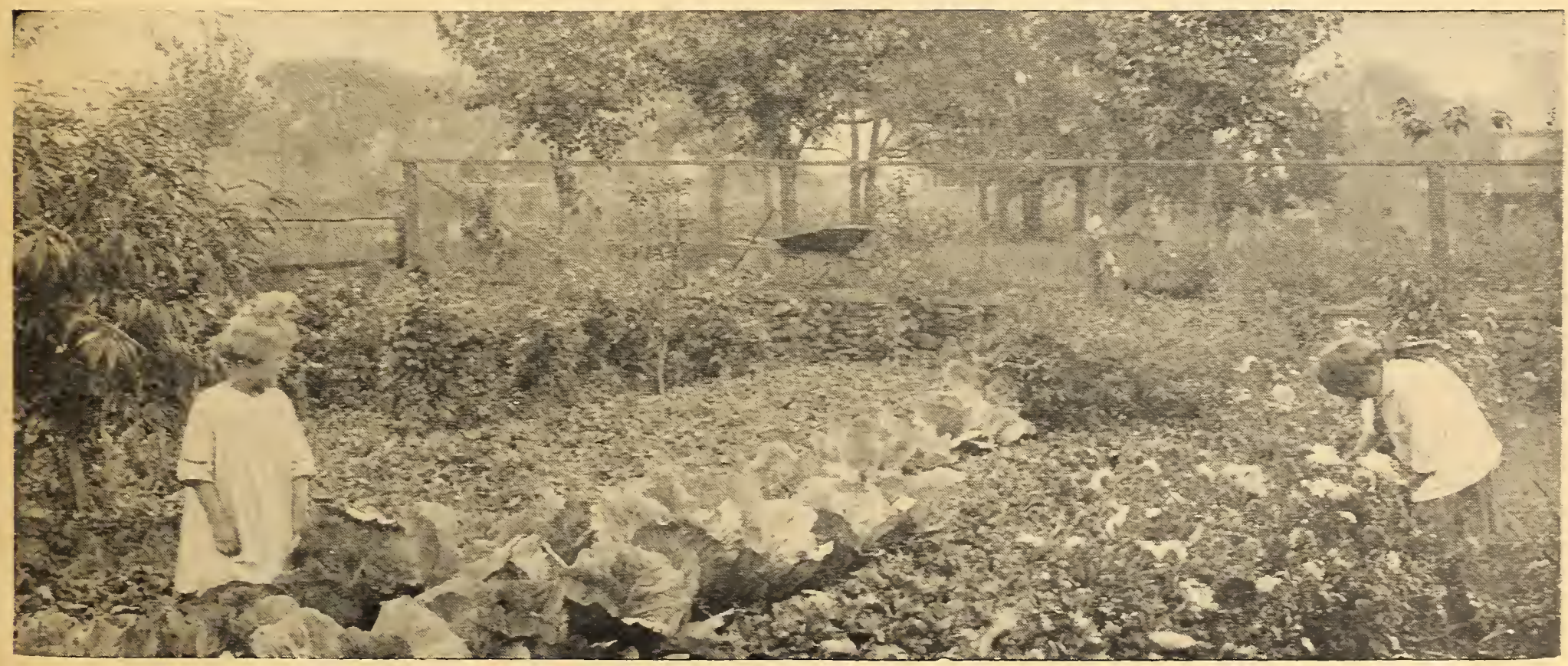




\section{Hardy and Productive Vegetable Seeds}

\section{GROWN IN THE NORTH FOR PARTICULAR GARDENERS}

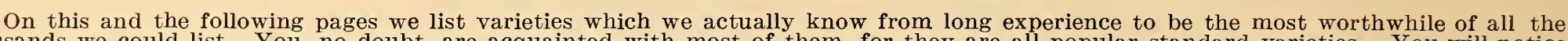

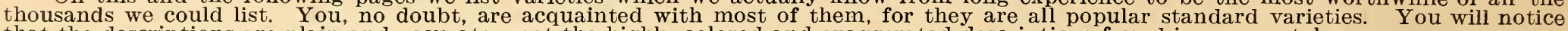
that the descriptions are plain and accurate-not the highly colored and exaggerated descriptions found in some catalogs.

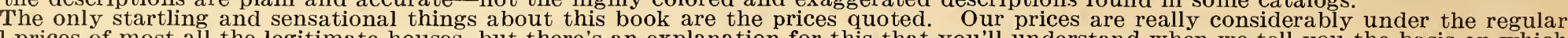

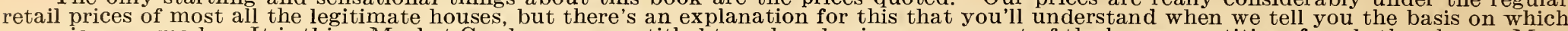

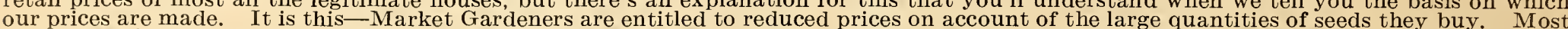

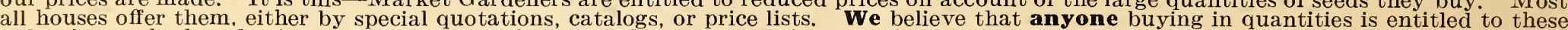

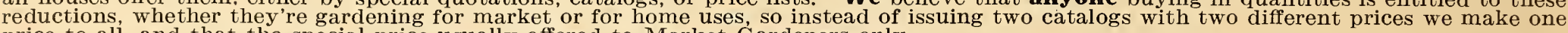
price to all, and that the special price usually offered to Market Gardeners only.

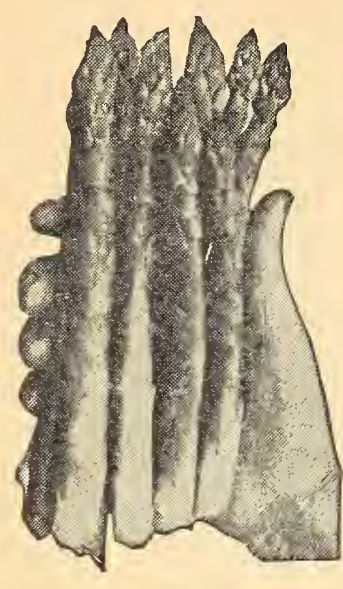

Conover's Collossal Asparagus

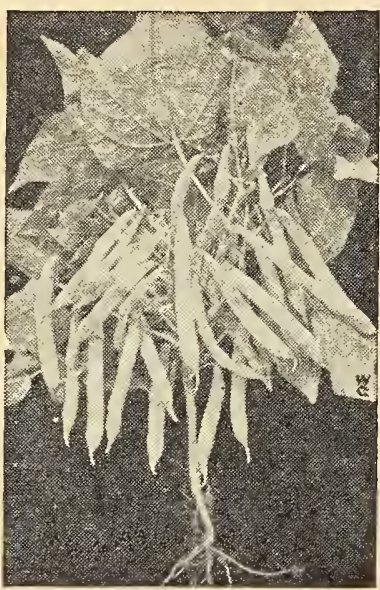

Burpee's Stringless Green Pod

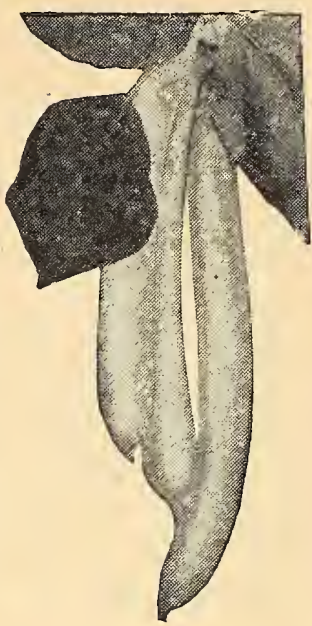

Early Wonder Wax

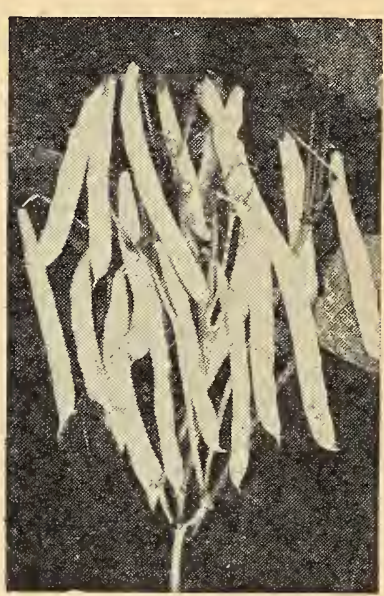

Davis ${ }^{\circ}$ White Wax

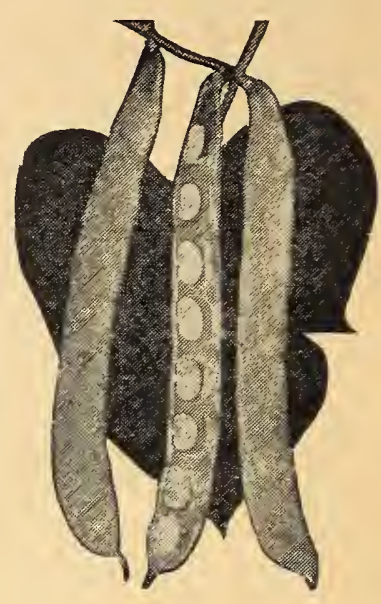

New BountifuI

\section{ASPARAGUS}

(One ounce will plant 100 feet of drill.)

CONOVER'S COLOSSAL-What's the use of listing a half dozen or more different varieties when this popular and most ex-
tensively used sort is the oue we would recommend to you? It's a large, bright green stalked variety, often tinged with purple at the top. You will find it to be very tender and of fine quality, Price, postpaid: lb., $75 \mathrm{c}$.

\section{BEANS}

(One pound will plant 100 feet of drill-

To insure early maturity, hardiness and resistancy, our seed Beans are grown in tions are ideal for the growing of Beans. Planting stocks are carefully selected for trueness to type and freeness of disease; growing crops are thoroughly inspected and rouged by experts.

\section{WAX-PODDED SORTS}

EARLY WONDER WAX (35 days)-Let us prove to you that this is one of the of the wax-podded beans. It grows a strong plant, well loaded with six to seven-inch pods. These pods are flat, plump and meaty, of a clear waxy-yellow color; very tender, stringless, brittle and of fine texture. Practi-
cally rust-proof, a bountiful yielder in good weather or bad, bearing early and long, the ideal bean for home or market garden. Plant it on our recommendation; if you are equal quantity of any other variety you may select from our list.

Price postpaid: Pkt., 10c; 7-oz. carton, $20 \mathrm{c}$ lb., 40c. Not prepaid: 3 lbs., 90c; $10 \mathrm{lbs}$.

IMPROVED GOLDEN WAX (40 days)The most popular of the wax-podded beans and one of the best. Very early and quite productive; pods 4 to $41 / 2$ inches long, very in form; flesh brittle, nearly stringless and in form; flesh brittle, nearly stringless and color; seeds are white, much mottled with
brown. Our Michigan grown stocks of this variety excel in hardiness, earliness and ength of bearing.
Price postpaid: Pkt., 5c, 7-oz. carton, 15c; lb., 30c. Not prepaid: 3 lbs., 75c 1bs. $\$ 2.25: 25$ lbs. $\$ 5.00$

PROLIFIC BLACK WAX (42 days)-A general favorite with market gardeners and home growers because of its fine quality, early maturity and productiveness. Medium small foliage. Longer bearing period than small foliage. Longer bearing period than most others and pods remain a long time in fine condition for snaps. Clear golden-
yellow color. Brittle and stringless. Seed oblong and jet black.

Price postpaid: Pkt., 5c; 7-oz. carton, 15c; lb., 30c. Not prepaid: 3 lbs., 70c; 10 lbs. $\$ 2.00 ; 25$ lbs., $\$ 4.50$.

DAVIS' WHITE WAX (45 days)-We recommend this as a canning variety on account of the length, uniformly perfect white seeds. Vine is rustless and very white seeds. Vine is rustless and very vigorous, bearing its pods near the center in
clusters. Pods are invariably quite long, clusters. Pods are invariably quite long, waxy-white, straight and handsome; when young are brittle, crisp and tender. Seed baking.

Price, postpaid: Pkt., 5c; 7-oz, carton, $15 \mathrm{c} ; 1 \mathrm{~b} ., 30 \mathrm{c}$. Not prepaid
10 lbs., $\$ 2.25 ; 25$ lbs., $\$ 5.00$.

\section{GREEN-PODDED SORTS}

BURPEE'S STRINGLESS GREEN POD (40 days) - An absolutely stringless, green, round-podded bean; stringless in all stages until full grown and ready to dry up. It surpasses all other bush beans in crisp, surpasses all other bush beans in crisp, beautiful appearance with its long, smooth, stout round and creasebacked, dark green, brittle pods about 5 inches long. Very prolific strong, vigorous grower; comes into bearing early and continues to produce long after nost other bush varieties are gone, the pods retaining their superb eating qualities to family garden who desire to combine quality with the heaviest production.

Price, postpaid: Pkt., 5c; 7-oz. carton, 15c; 1b., 30c. Not prepaid: 3 lbs., $75 \mathrm{c}$ 10 lbs., $\$ 2.25 ; 25$ lbs., $\$ 5.00$.

NEW BOUNTHFUL (42 days)-A distinct improvement in green bush beans that has The plant is of thrifty growth, and practically rust and mildew proof. Very hardy,
extremely early, very prolific, and bears continuously for several weeks. The crowning merit of this bean is in the rich, green pods, which are of large size, thick, broad, lat, extra long, very uniform in shape, solid, meaty and of high quality. They are melting, their own; moreover, the pods are absolutely stringless.

Price, postpaid: Pkt., 5c; 7-oz carton, 15c; lb., 30c. Not prepaid: 3 libs., 70c; 10 lbs., $\$ 2.15 ; 25$ lbs., $\$ 4.75$.

EARLY RED VALENTINE (40 days)The most largely planted variety of bush beans with our Southern friends; a splendid early, heavy-bearing variety, well adapted to variable soils and climates for market or hom use We advise caution in the purchase of Red Valentine Beans on account of the large quantities of flat-podded, tough, shucky beans that are sold every year through dealers whose inducement to buy is largely a lower price.

If you plant our Michigan grown stocks of Valentine Beans you are safe in this respect and sure of beans of the right quality. Ours is the true, round-podded stock, very early. a vigorous grower and very heavy bearer of medium sized, round, tender, finely flavored, medium green pods, about $41 / 2$ inches long; slightly stringy. Very uniform in ripening and truck growers consider our Red Valentine very profitable for shipping.

Price, postpaid: Pkt., 5c; 7-oz. carton, 15c: 1b., 30c. Not prepaid: 3 lbs., 70c; 10 lbs., $\$ 2.00 ; 25$ lbs. $\$ 4.25$.

LONGFELLOW (Empereur de Russe) (40 days)-If you like a green-podded bean 40 days - - If you like a green-podded bean It's a productive sort, of choice quality and very fine appearance. Pods are dark green, long, very slender, straight and round slightly stringy, tender and fine grained. We know you will like it.

Price, postpaid: Pkt., 5c; 7-oz. carton, 15c; 1b., 25c. Not prepaid: 3 lbs., 60c: $15 \mathrm{c} ; 1 \mathrm{~b} ., 25 \mathrm{c}$. Not prepaid
10 lbs., $\$ 1.75 ; 25$ lbs., $\$ 3.75$.

LATE REFUGEE (48 days)-Excellent summer variety; enormous yielder and very popular in some sections. The plants are unusually large, spreading, exceedingly hardy, with an abundance of foliage. Pods are perfectly round and straiglit, tender, and of excellent table qualities; good for both early and late planting. Very popular with canners. Seed light drab colo

Price, postpaid: Pkt., 5c; 7-oz. carton, 15c; lb., 25c. Not prẹpaid: 3 lbs., 65c 10 lbs., $\$ 1.90 ; 25$ lbs. $\$ 4.35$. 

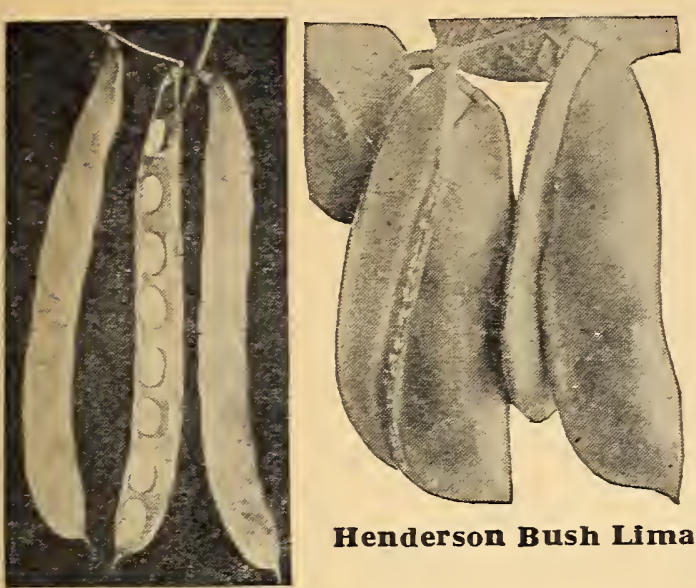

Henderson Bush Lima

Kentucky Wonder

\section{Beans-Continued}

\section{DWARF LIMAS}

HENDERSON'S BUSH LIMA (60 days)smaller but most proing a true bush form of small Lima or "Sieva." " Especially raluable because it suits all latitudes, North or South. Known in the South as the "Dwarf Butter Bean." It matures splendidly in Michigan where our seed is produced. The green beans of this sort are plump, very tender and of the true buttery Lima flavor. From July until frost, green beans can

abundance by planting this sort.

Price, postpaid: Pkt., 5c; 3 lbs., $75 \mathrm{c}$; $15 \mathrm{c} ;$ lb., 30c. Not prepaid
10 lbs., $\$ 2.50 ; 25$ lbs., $\$ 5.50$.

BURPEE'S IMPROVED BUSH LIMA (75 days)-A bush form of the large white Lima that has long been known and liked by gardeners all over the country. Very productire, pods and beans are of large ize and the flavor is unsurpassed.

Price, postpaid: Pkt., 5c; 6-oz. carton $15 \mathrm{c}$; lb., $35 \mathrm{c}$. Not prepaid
10 lbs., $\$ 2.75 ; 25$ lbs., $\$ 6.25$.

\section{POLE OR CORNFIELD}

(1/2 pound will plant 100 feet of drill30 pounds for an acre.

Pole Beans are much more productive than the bush varieties, and their bearing season is much longer. Though they require a little more care in handling, a few hills of pole beans in your garden this year will amply repay you for your extra trouble. KENTUCKY WONDER or OLD HOMESTEAD (75 days)-The most practically useful of the green-podded pole beans suitable for use as snaps. An early, very prolific sort. Vines are vigorous and very productive, bearing pods in large clusters. The pods are medium light green, very long. pods are medium light green, very long, and twisted, nearly round, entirely stringless, cooks tender and melting and always give cooks tender and satisfaction.

perfect satisfaction. Pkt., 5c; 6-oz. carton 15c; lb., 35c. Not prepaid: 3 lbs., 90c 10 lbs., $\$ 2.75 ; 25$ lbs., $\$ 6.25$.

LAZY WIFE (80 days)-So named because of the easy picking. A very popular bean in some localities. Pods are broad, thick, in some localities. Pods are broad, thick, very fleshy, entirely stringless and of a rich white and make a good dry bean for winter use.

Price, postpaid: Pkt., 5c; 6-oz. carton, $15 \mathrm{c}$; 1b., 35c. Not prepaid: 3 lbs., 90c 10 lbs., $\$ 2.75 ; 25$ lbs., $\$ 6.25$.

\section{FIELD BEANS}

(Plant 25 pounds to the acre-cultivate like potatoes.)

IMPROVED WHITE NAVY-Selected, pure, and of this, the standard field bean, is worth a premium over ordinary beans. Ou seed stocks are Michigan grown, hand-picked and sure to grow.

Price, postpaid: Pkt., 5c; 1b., 25c. Not prepaid: 3 lbs., 60c; 10 lbs., $\$ 1.75$.
RED KIDNEY - The good old-fashioned baking bean. The beans are of large size and very rich in flavor. A wonderful yielder on strong soil.

Price, postpaid: Pkt., 5c; 1b., 25c. Not prepaid: 3 lbs., 60c; 10 ỉbs., $\$ 1.75$.

NOTICE-Beans are quoted by Ne pound instead of meastre. pound is equivalent to 1 pint, pounds to 1 quart, 7 pounds to gallon, approximately

If you order at "not prepaid" prices your order will be sent by freight or express unless you include rates are found on page 17

\section{PLANT LIMA BEANS WITH THE EYES DOWN.}

The Lima has such heavy seed leaves that it can't turn over in the ground and push its way through the soil as do smaller seeds. It rots before it can make the turn unless it is in light soil or covered only slightly. The bean has to come through the oil edge first, the seed leaves opening on the edge when they swell and burst down the roots can s. Planted and the thin edge can start pushing upward and it will come to health growth without difficulty.

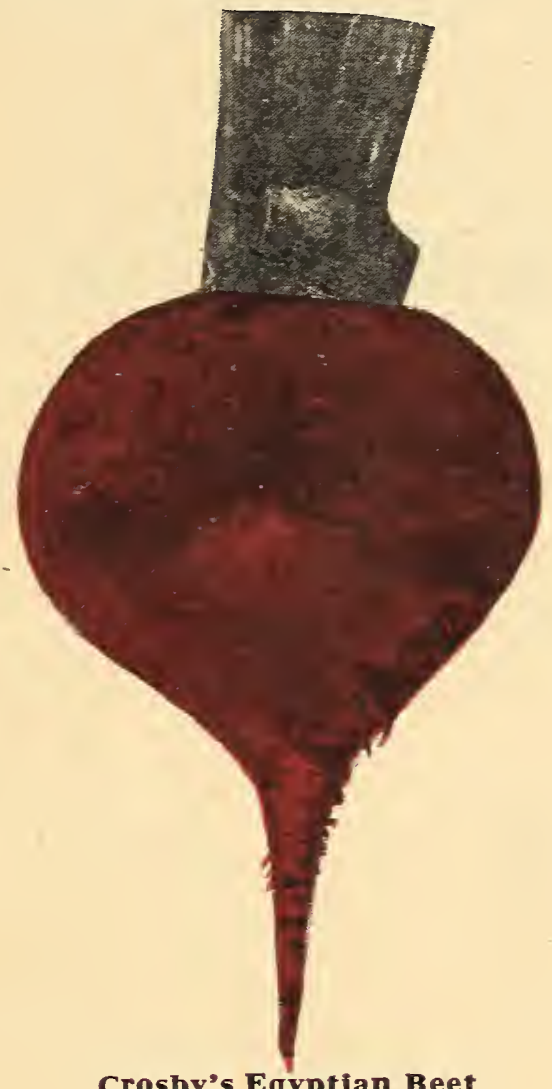

\section{TABLE BEETS}

(One ounce for 100 feet of drill.)

New varieties come and go but the following beets, year after year, maintain their popularity and hold their place right at the top of the list of really good varieties: CROSBY'S EGYPTIAN (45 days)-A favorite with every housewife wanting an early table beet that is just right in shape, color and quality. Excels in handsome form, a good size, small tops, very small tap-root, fine quality, and above all, quick, rapid growth. The flesh is deep red. Takes on its turnip shape rery early, a decided adand especially for a market where beets are old in bunches.

Price, postpaid: Pkt., 5c; oz., 10c; $1 / 4$ lb., 5 lbs. $\$ 3.00$

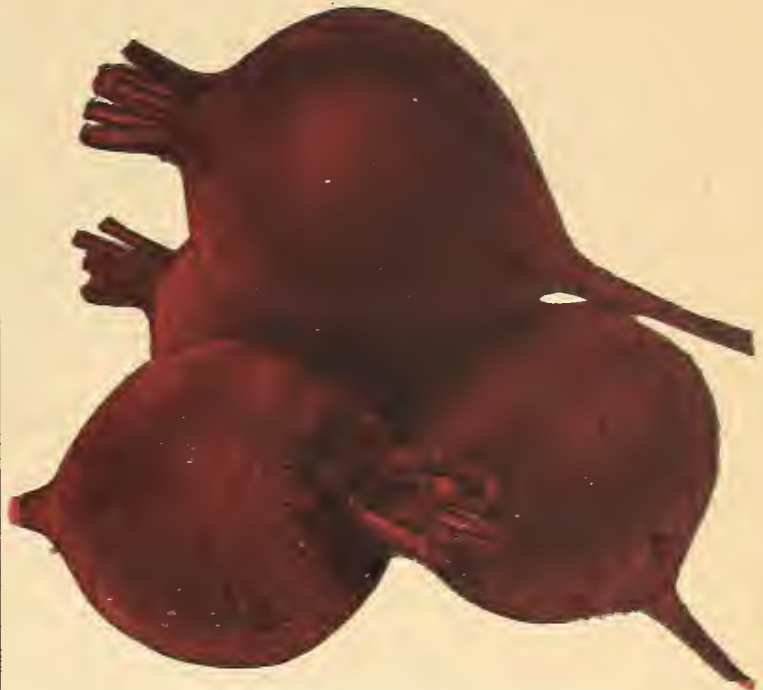

Detroit Dark Red Beets

DETROIT DARK RED (50 days)-If we were allowed to grow and to list but one variety of beets, this would be our choice Red Turnip Beet to be the finest main-crop all-purpose beet in cultivation. For the home garden it is especially desirable on account of its exquisite quality, being sweet, tecount of its exquisite quality, being sweet, tender and fine-grained, without any trace dark red color makes an attractive dish on your table. Splendid for canning

Price, postpaid: Pkt., 5c: oz., 15c; $1 / 4$ lb.,
30c. Not prepaid: Lb., 85c; 3 lbs., $\$ 2.40$ : $5 \mathrm{lbs} ., \$ 3.75$.

IMPROVED EARLY BLOOD TURNIP (45 days)-This splendid beet is early, and (45 days) - This splendid beet is early, and free from side or fibrous roots, being always smooth. Excellent for forcing for a main or summer crop, or for use in winter, as it is a good keeper. It always cuts and cooks and crisp and is in every way the standard sort for the home gardener.

Price, postpaid: Pkt., 5c: oz., 10c; $1 / 4 \mathrm{lb}$. 5 ibs.

CRIMSON GLOBE (50 days)-Tery fine table and market beet. Of fine shape, very small tap-root, deep crimson flesh of fine grain, surprisingly sweet flaror and unsurpassed quality. The foliage is small, nearly all deep red. Entirely free from fibrous rootlets, having only a slender tap-root. main crop purposes. Does well here and in the south.

Price, postpaid: Pkt., 5c: oz., 10c: $1 / 4$ lb. 25c. Not prepaid: Lb., 75 c; 3 lbs., $\$ 2.10$

LONG DARK RED (65 days)- - ery dark tenod winter keeper stands dry weather better than any other beet and keeps longest. Popular for fall and with advantage in July or August, as a second crop. It will not be injured by the October frosts and will produce in great abundance.

Price, postpaid: Pkt., 5c; oz., 10c; $1 / 4$ lb. $25 \mathrm{c}$. Not pr
5 lbs., $\$ 3.00$.

MIXED BEET SEED-A very carefully prepared mixture of best sorts for table use supply vou with beets throughout the season for table use, canning and storing for winter.

Price, postpaid: Oz., 5c; $1 / 1 \mathrm{lb} ., 15 \mathrm{c}$. no vegetable is coming into popular favor more rapidly than Swiss Chard. It is grom for its leaves only, as it does not mate a The leaves grow large and upright and as the outer leaves are cut more come from the

The mid-rib or center stem of each leaf is large and almost white and after trimming can be cooked and served like asparagus The leaf part can be cooked like spinach or
turnip greens or if desired the whole leaf curnip greens or if desired the whole, lea Price, postpaid: Pkt., 5c; oz., 15c; 1/4 1b. 


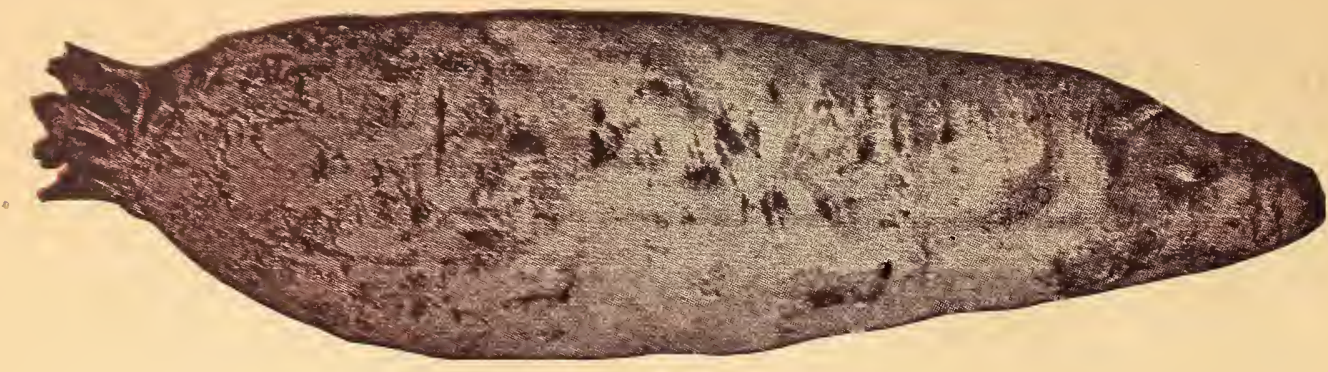

Mammoth Long Red Mangel

\section{MANGELS AND SUGAR BEETS}

The value of Sugar Beets and Mangels for stock feeding is clearly seen in the improved health and condition of the animals, the increased flow and quality of milk from cows and the saving in fodder. They yjeld enormously and can be grown at trifling cost, requiring but 5 to 6 pounds of seed per acre which, in turn, should produce from 25 to which, in turn,
40 tons of roots.

MAMMOTH LONG RED (110 days)The best long red mangel; very productive. It grows well above the ground and is easily it grows we

Price, postpaid: Oz., 10c; $1 / 4$ lb., 20c. Not prepaid: Lb., 60c; 3 lbs., $\$ 1.65 ; 5$ lbs. $\$ 2.50$

GOLDEN TANKARD (95 days)-The best yellow mangel; globe-shaped, easily harvested and very desirable.

Price, postpaid: Oz., 10c; 1/4 lb., 20c. Not prepaid: Lb., 60c; 3 lbs., $\$ 1.65 ; 5$ lbs.

KLEIN WANZLEBEN SUGAR (80 days)Largely grown for sugar. The root is
straight and even. A heavy yielder and straight and even.
very rich in sugar. Price, postpaid: $0 z ., 10 c ; 1 / 4$ lb., 20 c.
Not prepaid: Lb., 60c; 3 lbs., $\$ 1.65 ; 5$ lbs., $\$ 2.50$.

\section{CARROTS}

( $1 / 2$ ounce for 100 feet of drill-2 pounds for an acre.

DANVERS (70 days) - A half long orange carrot, grown largely on account of its great productiveness and adaptability to all productiveness and adaptability to all rot for the home garden and for field culture. The tops are of medium size. The mature roots are of medium length, six to eight roots are of medium length, six to eight
inches long, tapering uniformly to a blunt point. 'The flesh is deep orange, tender and of good quality. Although the roots of this variety at maturity are comparatively short they often produce as large a bulk as the longer field sorts and are more easily harPrice, postpaid: Pkt., 5c; oz., 10c; $1 / 4$ lb. 30c. Not postpaid: Lb., 70c; 3 lbs., $\$ 1.95$

GUERANDE or OX HEART (65 days)Especially desirable for soil so hard and stif it. The tops are comparatively small. The mature roots are four and one-half to five inches long, very thick, ending abruptly in small tap root. The flesh is bright orange, fine grained and sweet. When young the roots are desirable for table use as a medium good for stock feeding.

Price, postpaid: Pkt., 5c; oz., 10c; $1 / 4$ lb.
30c. Not prepaid: Lb., $75 \mathrm{c} ; 3$ lbs., $\$ 2.10$

WHITE AND YELLOW BELGIAN-The old favorite stock carrots.
Price, postpaid: Oz. $5 \mathrm{c} ; 1 / 4$ lb., $15 \mathrm{c}$.
Not prepaid: Lb., 50c; 3 lbs., $\$ 1.35 ; 5$ lbs.,

\section{CABBAGE}

(One ounce produces 2,500 to 3,000 plants. ounces will grow enough plants to set one acre.

We claim, and it's no idle boast, that our Cabbage Seed is second to none for sure heading qualities and all-around dependaheading qualities and all-around dependaility. It comes from the world's best There is no need for the listing of a great number of simply strains rather than distinct sorts simply strains rather than distinct sorts and are really the same as some older and better known kinds. We are confiden that in the kinds we offer all good qualitie other kinds we could list.

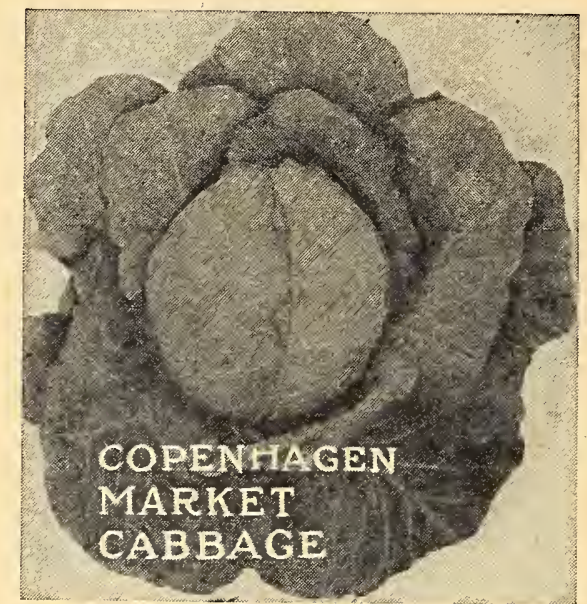

\section{WHERE THE BEST CABBAGF SEED IS PRODUCED.}

Cabbage seed is largely grown on Long Island in Washington near Puget Sound, in Holland and in Denmark. It is generally conceded that the most reliable seed comes from Denmark, and it is always the highes in price. We want our patrons to have the best, and therefore contract with reliable Danish growers for our requirements.

EARLY JERSEY WAKEFIELD (85 days) -This most excellent variety is the earliest and surest heading of first early cabbages for the market and home garden. Most gardeners depend upon it for the bulk of their extra early crop. The plants are exceedingly hardy, not only in resisting cold but other unfavorable conditions. They are compact and erect or very slightly spreading, with few outer leaves, which are smooth, thick, nearly oval and deep green. The stem is short. The heads are of medium size, very quality.

Price, postpaid: Pkt., 5c; oz., 30c. Not prepaid: $1 / 4$ lb., $75 \mathrm{c}$; lb., $\$ 2.75$.

ALL SEASONS (110 days)-A grand variety. We can safely recommend the All
Seasons Cabbage as one of the best and surest cabbages to grow, and for the market gardener one of the most useful, marketable and profitable. Perhaps the safest variety for the amateur to plant as it does well at all seasons and is a very sure cropper. The heads are dark blue in color and being tender and fine keeping are excellent for fall and winter. use.

Price, postpaid: Pkt., 5c; oz., 25c. Not prepaid: $1 / 4$ lb., 70c; lb., $\$ 2.50$.

DANISH BALLHEAD (120 days $)$-This winter variety is especially desired on account of its great solidity and its keeping qualities. The heads weigh more than other sorts of equal size. They are round as a ball, solid, fine grained, with few outside leaves; crisp, tender and sweet, and unsurpassed for boiling, slaw, sauerkraut, etc. Has been selected and perfected for over fifty years by the Danish gardeners, who prize clusively for Winter Cabbage and annually clusively for Winter Cabbage and annually export large quantities of it. It grows well standing hot, dry weather, and does not rot n wet seasons.

Price, postpaid: Pkt., 5c; oz., 35c. Not prepaid: $1 / 4$ lb., $85 \mathrm{c} ; 1 \mathrm{~b} ., \$ 3.00$.

COPENHA GEN MARKET (90 days)-The earliest large round-headed cabbage yet introduced. The heads are cabceptionally large for so early a variety, very solid and of large for so early a variety, very solid and of most excellent quality. The plants are vigorous but compact, with short stem and few outer leaves which are of rather upright growth. The leaves are medium light and smooth. This is a most excellent sort both for the home garden and market gardening trade. Our strain produces the characteristic large, round heads that for solidity and excellent quality make this variety so valuable.

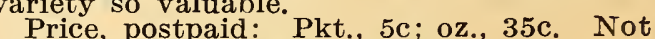
prepaid: $1 / 4$ lb., $85 \mathrm{c}$; $1 \mathrm{~b} .$, $\$ 3.00$.

EARLY FLAT DUTCH (100 days)-Standard second early sort, sure solid header, of even size, weight 10 to 12 pounds each; fine-grained and of good flavor. Stands long without bursting. It succeeds everywhere and is particularly suited to the South, as it resists heat well.

Price, postpaid: Pkt, 5c; oz, 30c. Not prepaid: $1 / 4$ 1b., $75 \mathrm{c}$; lb., $\$ 2.75$.

PREMIUM FLAT DUTCH CABBAGE (125 days)-Continued care and critical selection on the part of our grower has given us a very thoroughbred strain of this standard cabbage. The heads are of the bluish-green color, flat on top, and are solid and large. color, flat on top, and are solid and large. with short stem. It cuts white and crisp, with short stem. It cuts white and crisp, the flavor is excellent with no stringiness. This strain is slightly earlier and quicker growing than most of the Premium Flat a tendency to burst. We do not hesitate to recommend our stock to even the largest growers, as it has been so long bred to a standard that it can truly be called a pedigree strain.

Price, postpaid: Pkt., 5c; oz., 30c. Not prepaid: $\quad 1 / 4$ lb.. 80c; lb., $\$ 2.85$.

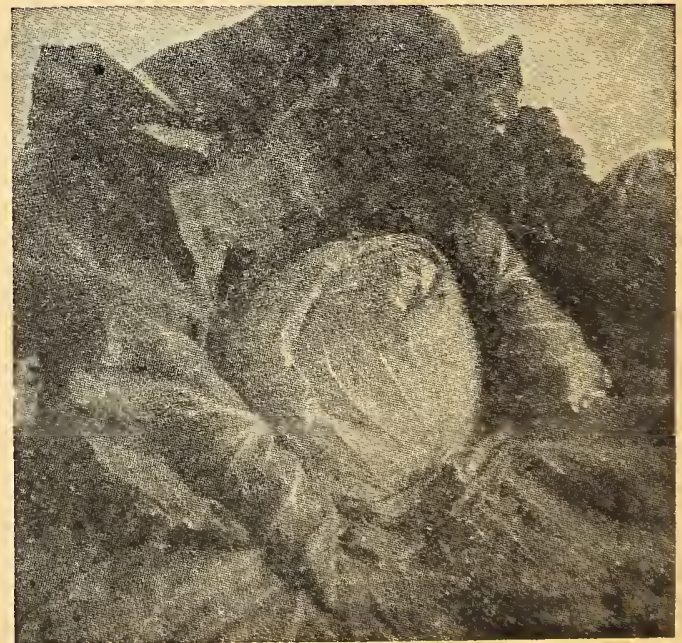

Early Jersey Wakefield 

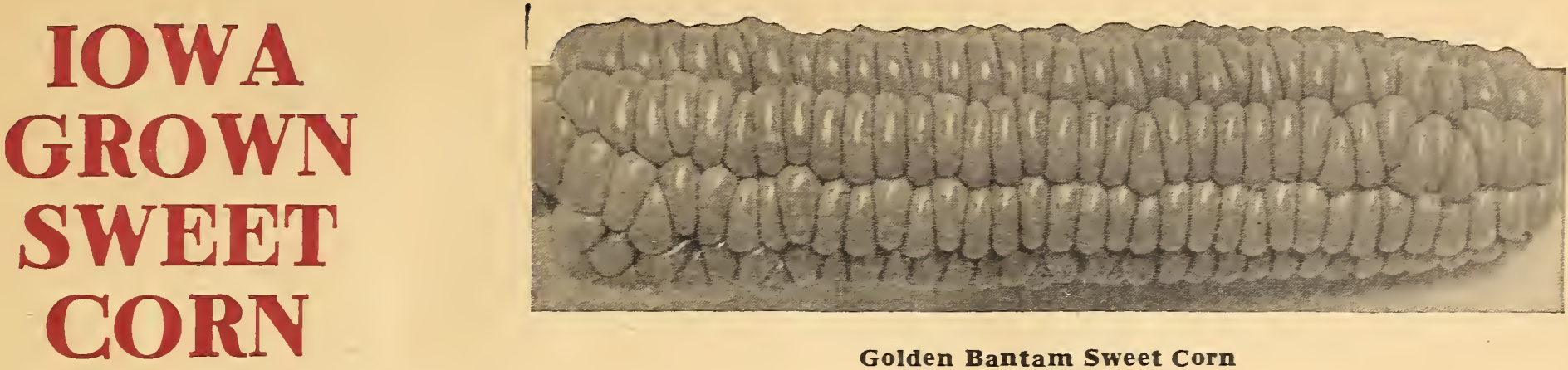

Golden Bantam Sweet Corn

( $1 / 4 \mathrm{lb}$. will plant 100 feet of drill, 12 lbs. for an acre.)

Jefferson Brand Sweet Corn, grown in Central and Northern Iowa, is well known for its early maturity and high sielding qualities. Iowa soils and climates are ideal for the growing of Quality Sweet Corn and one part of our organization and equipment has been built es-

pecially for the growing and handling of this crop. corering a wide area, enables us to segregate each variety, reducing possibilities of hybridization.

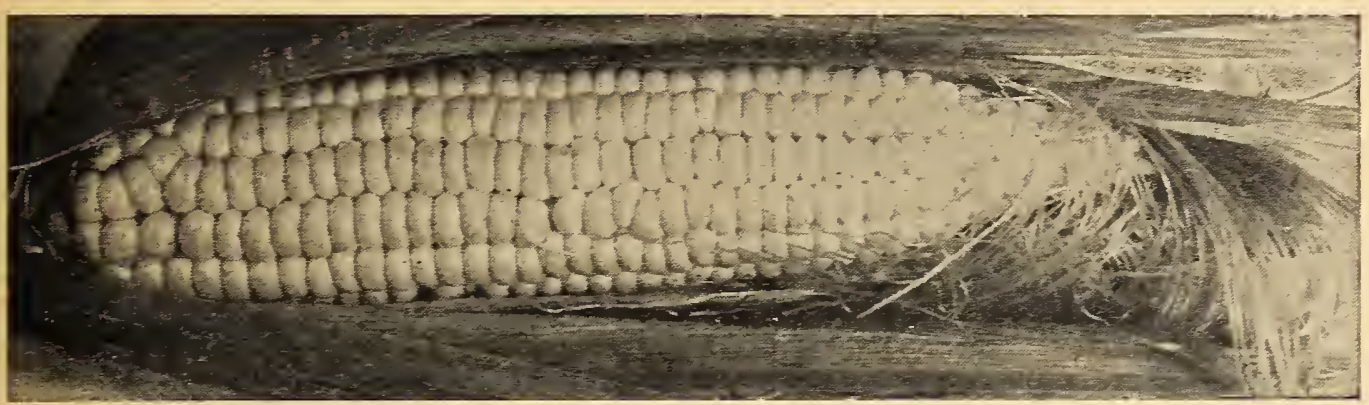

Stowell's Evergreen Sweet Corn

GOLDEN BANTAM (65 das $\mathrm{s})$ - This is such a big little variety that we can hardly find words to describe its true value. Golden in color, extremely early and most suras distinct in flaror as it is in color from that of the white rarieties, being almost literally "sweet "hite varieties, being almost literally having once tasted the flaror of Golden Bantam, the taste of other rarieties becomes Bantam, the taste of other varieties becomes six to seren inches long, and of the medium six to seren inches long, and of the medium size found most suitable to the table. The stock of the most splendid home garden and market rariety has been carefully selected and is decidedly superior to much that is offered.

Price, postpaid: Pkt., 5c; 6-oz. carton, $10 \mathrm{lbs} ., \$ 2.25 ; 25 \mathrm{lbs}$., $\$ 5.00$.

MAMMOTH WHITE CORY (70 dass)One of the best extra early rarieties for the market and bome garden. The ears are very large for so early a variety. The stalks are about four feet high, each generally bearing two large, finely-shaped ears. Twelve rowed, six to seren inches long, ver. symmetrical and handsome, selfom with any opening between the rows at the base. The grain is large, broad. rery white and of remarkably good quality for such an early sort.

Price, postpaid: Pkt., 5c; 7-oz. carton, $15 \mathrm{c}$ ibs., $130 \mathrm{c}$; 25 Lot prepaid: 3 lbs., $60 \mathrm{c}$

EXTRA EARLY ADAMS (Ready for the table 62 days after germination-_Not a sugar corn, but decidedly more hardy, permitting earliest planting, and on this
it is of much ralue to the gardener.

it is of much ralue to the gardener. $15 \mathrm{c}$; 1b., $25 \mathrm{c}$. Not prepaid: 3 lbs., $50 \mathrm{c}$; 10 lbs., $\$ 1.50 ; 25$ lbs., \$3.50.

EARLY MINNESOTA ( 75 days)-One of the best second early sorts for the market and the home garden. The stalks are about six feet high bearing one or two ears well covered with husks. The ears are about eight inches long, eight-rowed; kernels rery broad, white, sweet and tender, ket shrinking dereloped a stock of this standard variety which is remarkably uniform.

Price, postpaid: Pkt., 5c; 7 -oz. carton, $15 \mathrm{c} ; \mathrm{lb}, 30 \mathrm{c}$. Tot prepaid: 3 ibs., $65 \mathrm{c}$ 10 lbs., $\$ 2.00 ; 25$ lbs., $\$ 425$.

STOWELL'S EVERGREEN (90 dars)The standard main crop rariety of sweet corn for market and home use. The strong, vigorous stalks grow 6 to 7 feet high, and produce ears 8 inches long which hare 16 or more rows of the finest sugary grains. The reputation of this variety for productiveness is well and long established, and the fine, rich flaror and sweetness of the deep-set, tender, white grains have made it a great and popular favorite.

Our Iowa-grown stock is recognized ererwhere as the best trpe of its class. Our where as the best type of its class, Our
strain is large-eared. hardy, productive, sweet and tender, and remains a long time in cooking condition. $15 \mathrm{c}$; lb., 30c. Not prepaid: 3 libs., $60 \mathrm{c}$, 10 ibs., $\$ 1.75 ; 25$ lbs., $\$ 3.75$.

COUNTRY GENTLEMAN ( 80 days)-The finest and sweetest of all sweet Corns. It finest and sweetest of all Sweet Corns. It arrangement of the kernels on the cob, and when once used no other sort is quite good when once used no other sort is quite good
enough. The milky kernels are plump, pearly white and tender. A very heary husk protects this corn so that it retains its tenderness and keeps it "in the milk" a surprisingly long time. Another good point is its prolificacy, rarely producing less than 9 inches in length; cobs small and grain is rery deep.

Price, postpaid: Pkt., 5c; 7-oz. carton, 10 lbs., $\$ 1.90 ; 25$ lbs., $\$ 4.00$.

\section{OUR OWN SUCCESSION COLLECTION OF SWEET CORN}

- The following rarieties. when planted at the same time, will produce a continuou supply of Sweet Corn of finest quality, from sweet and tender, and remains a long time
GOLDEN BANTAM-The earliest rariety.

EARLY MINNESOTA-Second earIy.

COUNTRY GENTLEMAN-Medium late. STOWELL'S EVERGREEN-Late.

We make the following special prices for this collection:

17 -oz. carton, each of the 4 rarieties, $50 \mathrm{c}$ prepaid.

1 pound each of the 4 rarieties, $\$ 1.00$, prepaid.

3 pounds each of abore 4 rarieties, $\$ 2.25$, not prepaid.

10 pounds each of above 4 rarieties, $\$ 7.00$, not prepaid.

\section{POP COR N- SELECTED FOR SEED}

AUSTRALIAN HULLESS-AIso known in some sections as Japanese Rice, Tom Thumb, or Bumblebee Pop Corn-

The Australian Hulless is a dwarf-growing corn, a heary yielder of attractive ears, peculiar in form, being nearly as thick as strains of Thite Rice, only longer and slimmer and pearls white in color, but its crowning merit lies in its popping quality, fine flaror and absence of hull or shell.

Price, postpaid: Pht., 5c; T-oz. carton, $15 \mathrm{c}$ : 1b., $30 \mathrm{c}$.

MONARCH WHITE RICE-Ererybody knows the old Fariets named White Rice. Our strain is an improrement, with large Our strain is an improrement, with large duced.

Price, postpaid: Pkt., $5 \mathrm{c}: \overline{7}$-oz. carton, $15 \mathrm{c}$ $\$ 1.50$.

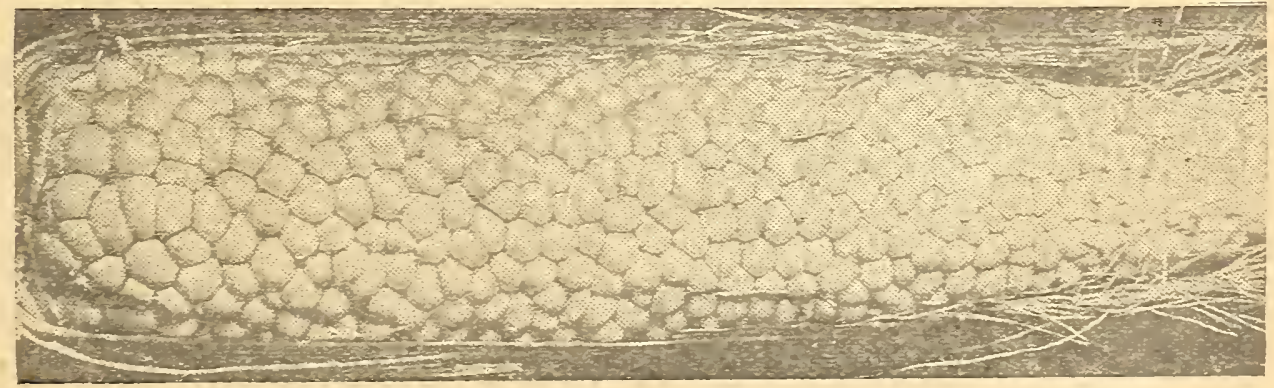




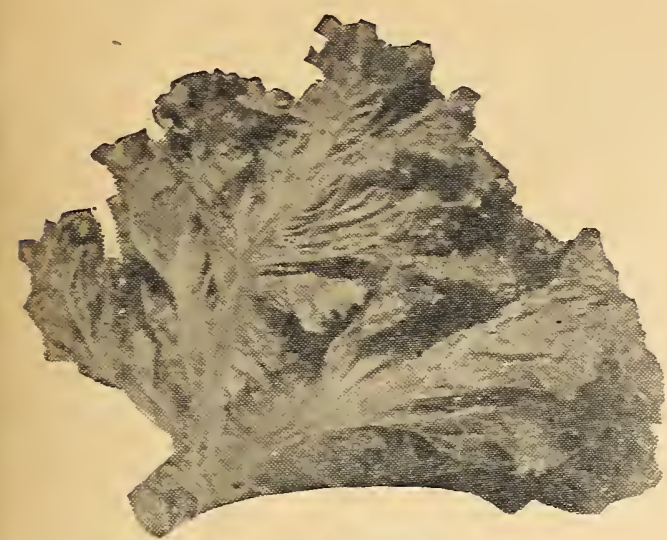

Black Seeded Simpson Lettuce

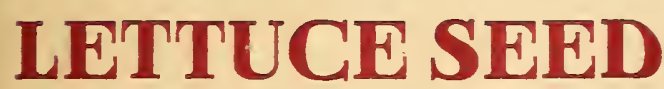

( $1 / 2$ ounce for 100 feet of drill.)

BLACK SEEDED SIMPSON ( 45 days)One of the best for sowing outdoors where an exceedingly tender leaf is desired. The color is an attractire light 5ellowish-green. the large outer ones are very tender. This the large outer ones are rery tender. uniformly attractire and remains of excellent quality a rery long time.

Price, postpaid: Pkt., 5c; oz, $15 \mathrm{c} ; 1 / 1 \mathrm{l}$. SIMPSON'S EARLY CURLED (45 days)A rerv extensirelr used earl 5 loose leaved or clustering variets. The leaves are light green in color, slightly frilled and much green in color, slightls frilled and much pecially adapted for sowing thickly and cutting when the plants are young.

Price, postpaid: Pkt., 5c; oz., 10c; 1/4 lb.,
30c. Not prepaid: Lb., 90c; 3 lbs., \$2.50.
GRAND RAPIDS (12 dars)-As a lettuce for greenhouse forcing, undoubtedly stands at the head of the list, being of quick growth. hardy, little liable to rot and remaining in condition sereral dass after being fit to cut. The plant is upright and forms a loose cluster of large, thin, bright green leares. sa royed. finely crimped at edges. T

Price, postpaid: Pkt., 5c: oz., 20c; $1 / 1 \mathrm{lb}$. 50c. Not prepaid: Lb., $\$ 1.35,3$ lbs., $\$ 3.75$.

SELECTED BIG BOSTON ( 5 da das)-The popularity of this Head Lettuce certainly covers a wide area. A large cabbage rariets, forming big, ret compact, tender and crisp heads of rich rellow color inside and deliciously sweet. Adapted to open ground for summer and fall use, or to growing in frames or to force in cool greenhouses. Withstands adrerse $\pi$ eather conditions.

Price, postpaid: Pht., $5 \mathrm{c}$; oz., 20c; $1 / 1 \mathrm{lb}$. 50c. Lot prepaid: Lb., \$1.35; 3 lbs., \$3.75.

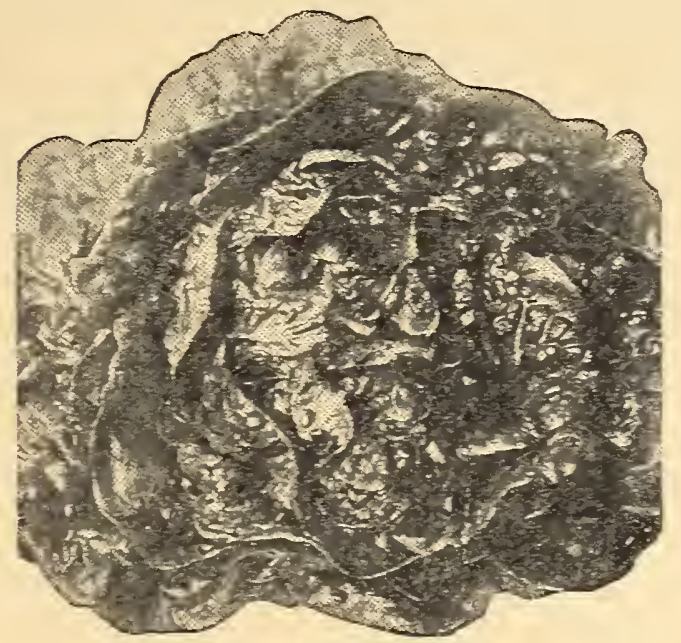

Improved Hanson

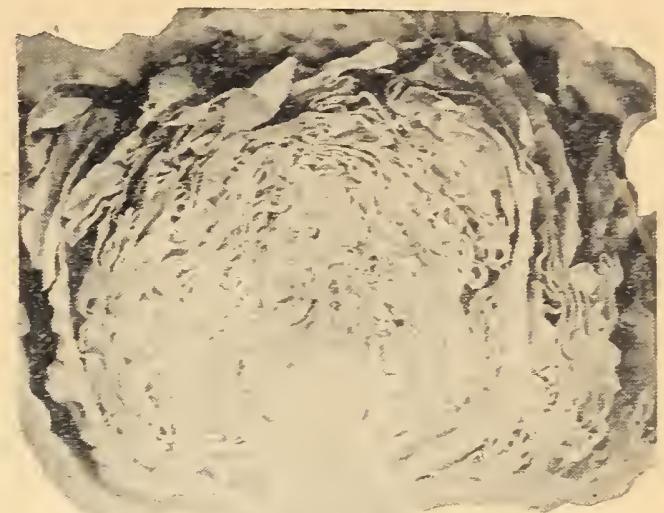

Selected Big Boston Lettuce

EARLY PRIZEHEAD (45 dars) - The best of the large, thin-leared clustering sorts for the home garden. The leares are vert brownish-red at the edges and are exceedingly tender, crisp and sweet, forming a large loose head. Stands a long time without Price, postpaid: Pht., 5c: oz., 15c: 1/t lb. IMPROVED HANSON HEAD (5j dars)One of the most raluable of the crisp heading sorts, in all respects one of the rery best stand extremes of weather better, perhaps. than any other of the "crisp heading" sorts. heads are hard, tender and crisp, with a blanched appearance in the center. The table quality is excellent, wholly free from bitterness and remains in splendid condition for use long after it has reached maturity Price, postpaid: Pkt.. 5c;oz., 15c; $1 / 1$ lb.,
45c. Not prepaid: Lb.. \$1,25:3 lbs., \$3.50.

\section{CHOICE MUSKMELON SEED}

( 1 ounce of seed will plant 60 hills. 2 to 3 pounds per acre.

SELECTED OSAGE ( $\bar{\zeta}$ dars)- $-\pi$ e give particular attention to our strain of Osage Helon, each rear carefully selecting our a pedigreed strain. Special care has been exercised to increase thickness of the fiesh and to derelop the rich, deep salmon color and to derelop the rich, deep salmon color
and fine flaror. The fruit is medium in size, oral in shape, slightly ribbed, dark green in color, and just nicely netted. The Osage is the farorite Iruskmelon on many
markets on account of its rich delicious markets on account of its rich delicious soils, where other varieties produce poor no other melon will do better.

Price, postpaid: Pht, 5c: oz, 15c; 1/4 lb., 45c. Not prepaid: Lb., \$1.25; 3 lbs., \$3.50;

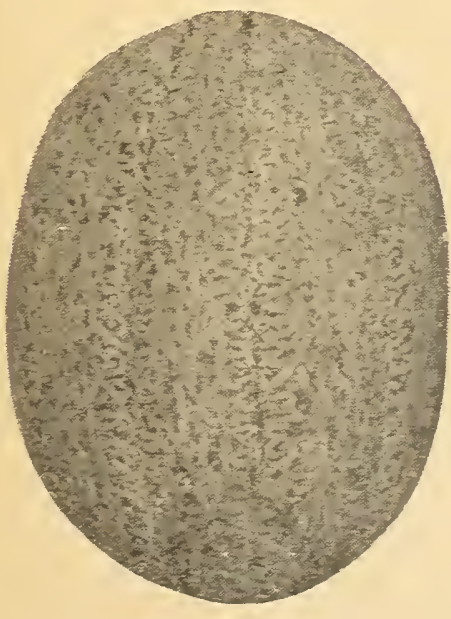

Selected Osage
EMERALD GEM ( $/ 0$ dats $)$ - While too soft to stand shipping, it is unequaled for home use or near-by markets. Strong, rigorous growth and rery prolific. in diameter. The skin is a rich, deep emeraldgreen. Flesh is very thick, with thin rind and small seed carity, crrstalline in appearance, and of a rich salmon color
Price, postpaid: Pkt., 5c: oz

40c. Not prepaid: Lb., \$1.15:3 lbs, \$3 25

TIP TOP (90 dars)-This wonderfully fine melon should be planted br all melon growers. Erers melon produced, whether big or little. early or late, is a good one; sweet, juicy finest flavor, firm-fleshed and eatable to the outside coating. Its appearance on the market is rers attractire- sells on sight. The ribbed and moderately netted. Flesh rich

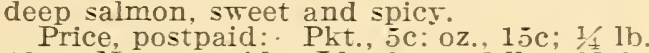
$40 \mathrm{c}$. Not prepaid: Lb., $\$ 1.15 ; 3$ lbs., $\$ 3.25 ;$
5 lbs. $\$ 5.00$. ROCKY FORD ( 75 dars)-The arerage man, when he "Tants the best melon, calls for
RockT Ford. No melon erer introduced has been as popular or is so worthy of its popularity. Then reads for shipping,

flesh is a greenish-white. Sweet and luscious small seed carity. It does not attain large size but is a great farorite with all classe qualitr among muskmelons. We ofier type. $30 \mathrm{c}$. Not prepaid: Lb., 90c; 3 lbs., $\$ 2.50$
5 lbs., $\$ 4.00$. BANANA ( 85 days) - Surpasses all others in rich salmon. The quality is first-rate wher the melon is thoroughily ripe. It grows prolific. By many this melon is considered of superb quality; it is essentially a home garden variety. Plant some for rour county 40c. Not prepaid: Lh., \$1.15;3 lbs., $\$ 3.25$ EXTRA EARLY HACKENSACK -Ripens a meek Rock Ford and is considerably than the round melon of very fine quality, deeply melon is more delightful; flesh light green and sugars. Has all the good pointsPrice, postpaid: Pkt., 5c: oz.. 15c; 1/ lb.,

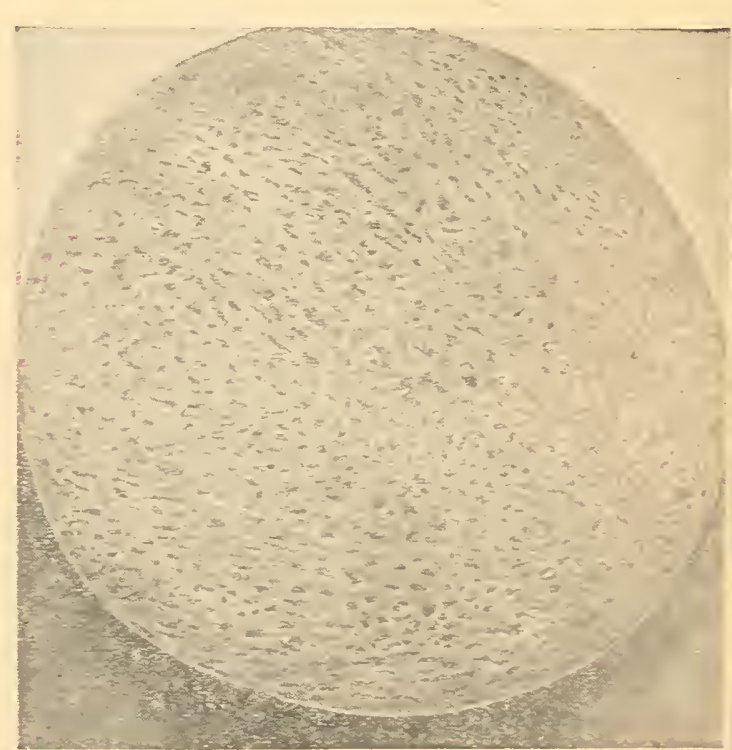




\section{NORTHERN GROWN ONION SEED}

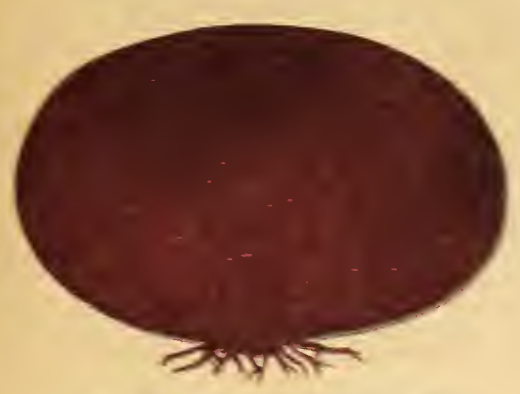

Large Red Wethersfield

One ounce to 100 feet of drill. Four pound: per acre.

LARGE RED WETHERSFIELD 125 daTS - Tert popular. a sure and heart yielder The best heeper, grows to an immense size. solid. oral-shaped. flattened on top: skin purplish-red. smooth and glossr: flesh White The best rariets for poor or drs soil.

Price, postpaid: Plt., 5c: oz.., 20c: $1 \frac{1}{5} 1 \mathrm{~b}$. 60c. Not prepaid: Lb., $\$ 2.00 ; 3$ lbs., $\$ 5.50$ $5 \mathrm{lbs} ., 57.50$.

SOUTHPORT RED GLOBE 135 daTs This most excellent medium earl or main crop red rariets produces bulbs of medium to large size, ideall slobe-shaped, hith rer smonth, slosss surface. Fers small neck and The flesh is white, inged with light purple, mild, vers fine srained and tender. Extensirely stoun for home use as well as the market. One of the best heepers and for shipping.

Price, postpaid: Pht., 5c; oz., 20c; 1/4 lb 6.5c. Not prepaid: Lb., \$2.25;3 lbs., \$6.25. $5 \mathrm{lbs}$., $\$ 10.00$.

PRIZETAKER 135 dars)-This handsome rariets is a splendid type of the celebrated Spanish fancy onions, which are annuall imported into the tnited States from Spain and sold br confectioners and fruiters in our large cities at from 25 to 50 cents each. The onions gromn here quite riral the imported ones in great beauts and enormous size. The outside skin is of a greenish-rellow color, while the flesh is white, sweet, and mild

Price, postpaid: Pht., 5c; oz., 25c; 1/ $1 \mathrm{~b}$. 75c. Iot prepaid: Lb., \$2.15;3 lbs.; $\$ 6.00$ $5 \mathrm{lbs} ., 59.25$

YELLOW GLOBE DANVERS (125 daIS)One of the most extensitel used main crop rellow onions for the home garden and market. Bulbs are of medium t.o large size, uniformls globe-shaped. with smali neck and ripen rers erenly. Shin is rich coppers. rellow. Flesh creami white, crisp and of mild and excellent flaior. Keeps rert mel and is excellent for shipping.

Price, postpaid: Pht., 5c; oz., 20c; $1 \frac{1}{2} 1 \mathrm{~b}$. 60c. Not prepaid: Lb., \$2.00; 3 lbs., $\$ 5.50$

SOUTHPORT YELLOW GLOBE 125 dars-Ters similar to the Southport Re Globe, except that it arerages a trifle smalle and matures a little earlier. The shin is a rich brownish-rellow: the flesh white, crisp and fne-srained. Great care has been giren uniformitr of size, shape, small nechs and heary rield.

Price, postpaid: Pht., 5c; oz., 20c; 16 lb $60 \mathrm{c}$. Not prepaid Lb., \$2.00;3 lbs., $\$ 5.50$; SOUTHPORT THITE GLOBE (125 daIs - Thite Globe Onions command the highest shaped and free from stain. Our Southport White Globe Onion meets these requirements, haring a thin skin of purest whiteness. The mild. As soon as ripe the bulbs should be stored in a cool, dark shed or drr cellar.

Price, postpaid: Pkt., 5c; oz.., 25c; $1 \frac{1 \mathrm{~b}}{1 \mathrm{~b}}$. soc. Not prepaid: Lb., \$2.50;3 lbs., $\$ 4.00$ $5 \mathrm{lbs}$, $\$ 11.25$.
WHITE PORTUGAL OT AMERICAN SILVER SKIN (115 dass)-Bulbs medium size, ripening earls and uniformls. With delicate and mild flaror. L L delicate and mild flaror.

Price, postpaid: Pht., 5c:0z., 25c; $121 \mathrm{~b}$. prepaid: Lb. $\$ 2.50 ; 3$ lbs., $\$ \div .00$ $51 \mathrm{bs}, \$ 11.25$.

\section{ONION SETS}

The Easiest Way to Grow Large Onions. Was to Grow Bunch onions.

Prices subject to market. Write for prices on larger guantities.

YELLOW BOTTOM SETS-Medium size fine dry sets. Planted extensirels for marke and home use. Price, postpaid: Pt. $20 \mathrm{c}$ s1.00; bushel. $\$ 3.50$.

RED BOTTOM SETS-Tery popular in the Northern States. 1 good keeper. Price, postpaid: Pt., 20c; qt., 30c; 4 qts. $\$ 3.50$.

WHITE BOTTOM SETS-Market gardeners plant these $\pi$ hite sets in rerr large quantities.

Price, postpaid: Pi., 20c; qt., 35c: 4 qts.
1.20. Dot prepaid: Pech, $\$ 1.20:$ bushel 81.20

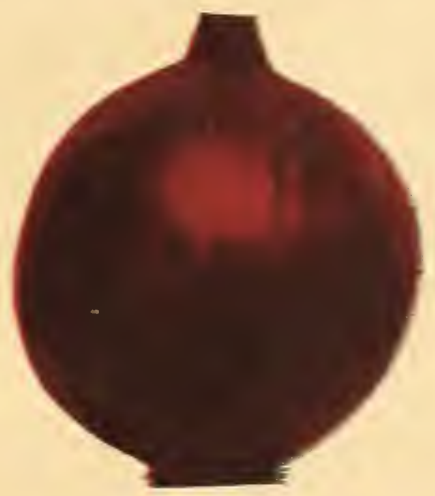

Southport Red Globe Onion

\section{PEPPER}

(One ounce of seed will produce about 1,500 plants.

RUBY KING (130 dass-Ters large and attractire. The plants are about two and one-half feet high, rigorous, compact and productire. The fruits are often four to green color when roung, bright red when green color when roung, bright red when
ripe. The flesh is thick and mild-1larored. One of the best parieties or mangoes or stufied peppers.

Price, postpaid: Pht., 5c; 1/2 oz., 25c: Oz., $40 \mathrm{c}$

LARGE BELL or BULL NOSE (130 daTs)Sometimes called sweet Mountain The plants are rigorous, about two feet hish. compact and rert productire, ripening their large, with thick, mild flesh of excellent qualits. The color is deep green when fruit is joung, bright crimson when ripe.

Price, postpaid: Pht., 5c; 1/2 Oz., 20c: $0 \mathrm{z}, 35 \mathrm{c}$

PIMENTO (125 dars)-The fruits of this rer productire sort are exceptionall smooth and glosss, of good size, medium length and attractire color. The flesh is thick and solid,
mild and of rerr fine flaror. Desirable not only for salads and stuffed peppers but it is

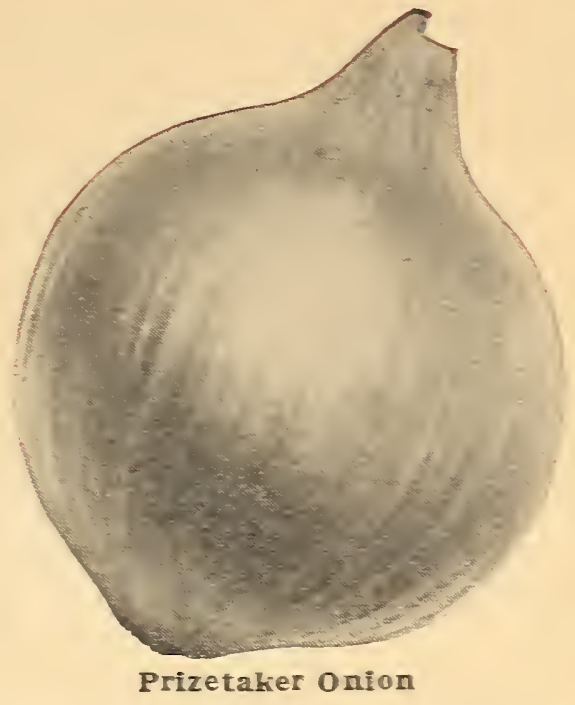

also the sort used largely br canners. The plants are vigorous and upright, about two deep sreen when roung, becoming deep Price

LONG RED CAYENNE 110 dass - 1 TellCA ENrietr haring a slender. thisted and pointed pod about four inches long. The color is deep green Then flesh is extremels strong and pungent.

Price, postpaid: Pht., jc; 1/2 oz. 20c:

\section{SPINACH}

BLOOMSDALE OF SAVOY-LEAVEDThe earliest rariets. Plant is of upright leares. Is Tert hards.

Price, postpaid: Pht., jc; oz., 10c; 1 t $1 \mathrm{~b}$. $25 \mathrm{c}$. Hot prepaid: Lb., $50 \mathrm{c} ; 3 \mathrm{lbs} ., \$ 1.35$

\section{SA L S I F Y O R VEGETABLE OYSTER}

MAMMOTH SANDWICH IS LA N Dless liable to branch than the other sorts. The tops are crass Intaluable for market gardener $50 \mathrm{c}$.

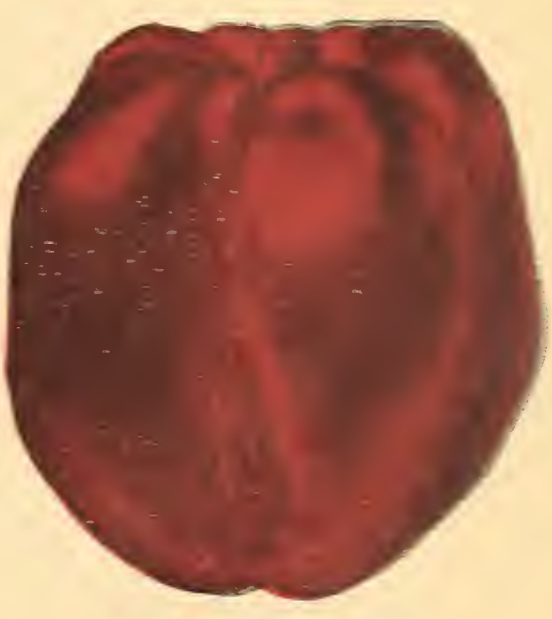

Large Bell Pepper 


\section{SELECTED SEED PEAS}

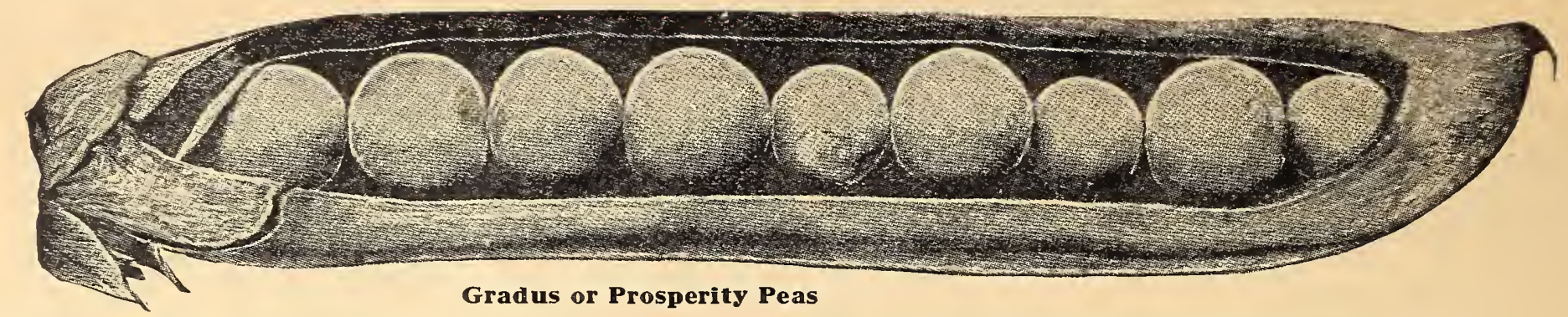

YOne pound will plant 100 feet of drill. 60 pounds for an acre.)

\section{0}

The wrinkled varieties are more sensitive to cold wet weather than the smooth seeded sorts but are of superior quality. All varieties growing more than one and one-half four to six inches high. This support is usually given by sharpened branclies of trees set between the double rows. The crop should be gathered as fast as it is fit for use. If even a fer pods begin to ripen not use. will new pods cease to form, but those partly AMERICAN WONDER (52 days)-Height 12 inches. This variety heads the list of Peas in flavor and quality. It is a cross between the well-known Champion of England and the Little Gem and has the merits of both, together with features not found in either of the parent varieties. The vines containing five to eight large, exceedingly sweet, tender and well-flavored Peas. This is the earliest of the dwarf, wrinkled varieties, being nearly as early as the smooth sorts. The seed is medium sized, wrinkled and pale green. These Peas are especially adapted to family use as they require no brush or ther support.

Price, postpaid: Pkt., 5c: 6-oz. carton, 15c; lb., 35c. Not prepaid: 3 lbs., 75c;

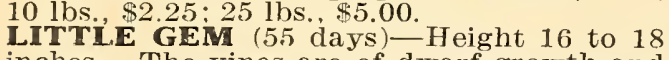
inches. The vines are of dwarf growth and produce an abundance of round, well-filled pods $21 / 2$ to 3 inches long, only three days after the American Wonder. The Peas are green, wrinkled, of sweet, delicious flavor and excellent quality. One of the best for family use. It remains fit for use longer than the American Wonder and Nott's sweeter.

Price, postpaid: Pkt., 5c; 7-oz. carton, $15 \mathrm{c}:$ lb., 30c. Not prepaid: 3 lbs., $70 \mathrm{c}$;
$10 \mathrm{lbs} . \$ 2.15$; $25 \mathrm{lbs}, \$ 4.75$.
NOT'S 12 inches. This is a very fine, highly bred variety of close, compact, dwarf growth, with quite large pods, fully one-third larger than almost as early. The pods average 3 inches in length. They are well filled to the ends in length. They are well filled to the ends
with peas of large size and unusually sweet

\section{STIM=(U)-PLANT PLANT STIMULANT TABLET}

\section{Whith no useless, wasted filler. You simply insert} water at rate of 4 tablets per gallon and apply as liquid manure.

\section{MAKES A WONDER GARDEN.}

STIMUPLANT greatly increases productiveness, color and flavor of fruits, berries and vegetables, and makes beautiful, richly fragrant flowers in abundance. Reports from users all over the country--both amateurs and professionals--praise it highly, and many buy five to ten thousand tablets at a time.

Prices, postpaid: Small size, 25c; 100 tablets, $75 \mathrm{c} ; 1,000$ tablets, in bucket, $\$ 3.50$.

flavor. So closely are the peas packed in the pods that they are flattened against each other at the sides, as in the Potato Limas. Price, postpaid: Pkt., 5c; 6-oz. carton, $15 \mathrm{c} ; 1 \mathrm{~b} . \$ 35 \mathrm{c}$. Not prepaid:

10 lbs., $\$ 2.25 ; 25$ lbs., $\$ 5.00$. ches. This is another early dwarf wrinkled pea that is very sweet and good. A splendid variety for either the home garden or for market purposes. Pods are $31 / 2$ inches long, ends square, and is packed tight with peas. In quality it cannot be surpassed, and in varieties. It is similar in appearance and quality to Nott's Excelsior, and has all the good points necessary in a successful variety. When it comes into competition with other varieties on the markets it is always the best selling kind and the most satisfactory to handle. It is a variety we recommend strongly.

15c. lb, postpaid: Pkt., 5c; 6-oz. carton, 10 lbs. $\$ 2.25$; 25 lbs., $\$ 5.00$. --Height 30 inches. By careful selection and growing we have developed a stock of this smooth blue pea of unequaled evenness in growth of vine and early maturity of pods in growth of vine and early maturity of pods green peas of good flavor. The pods are of green peas of good flavor. The pods are of
good size, about two and one-half to two and three-fourths inches long. Seed small, smooth, and bluish green in color. This sort matures all of its crop at once and is an invaluable variety for market gardeners and canners.

Price, postpaid: Pkt., 5c; 7-oz. carton, 15c; lb., 30c. Not prepaid: 3 lbs., 65c; 10 lbs., $\$ 2.00: 25 \mathrm{lbs}$., $\$ 4.50$

FIRST AND BEST (48 days)-Height 30 inches. This is the earliest and most even strain of first early white peas, maturing so well together that sometimes a single picking will secure the entire crop. The vines are vigorous and hardy, bearing three to seven straight pods of good size, about two and one-half to two and three-fourths inches long, each containing five to seven medium sized, smooth peas of fair quality. Seed small, smooth peas of fair quality. offer is much superior to most on the market and more even than similar strains.

Price, postpaid: Pkt., 5c; 7-oz. carton, $15 \mathrm{c}$; lb., 30c. Not prepaid: 3 lbs., 60c; 10 lbs., $\$ 1.85 ; 25$ lbs., $\$ 4.25$

EVERBEARING (60 days)-Height $21 / 2$ to 3 feet. As the name indicates, this variety continues long in bearing and is very prolific. It is probably the best sort for late Summer and Autumn use. The broad pods, which are of a nice green color, average three inches in length. The Peas are very large, green, in length. The Peas are very large, green, cook very quickly, are tender and of superior cook very quickly, are tender and
flavor. Excellent for family use.

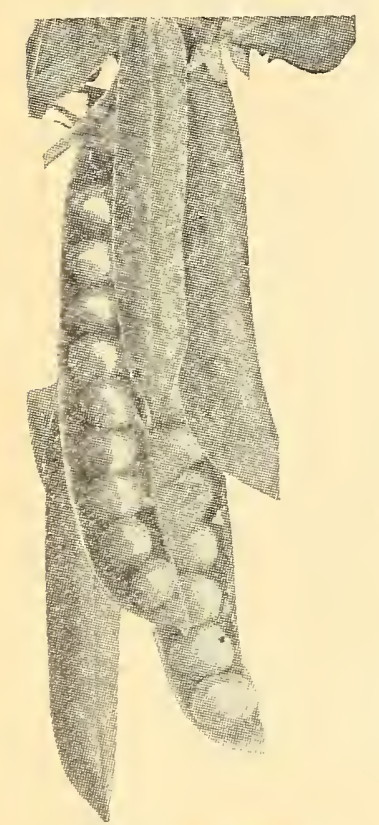

Nott's Excelsior
GRADUS or PROSPERITY (55 days)Height 30 inches. This remarkable pea is it is also nearly as early as the small, round, extra early sorts. It is hardy and may be in the spring, along with smooth peas. The pods are of a light green color and measure pods are of a light green color and measure
4 inches or more in length, being as large as Telephone and equally as well-filled with luscious peas -8 to 10 in a pod. The peas
are of first-class table quality and retain their are of first-class table quality and retain their
color and attractive appearance after cooking. Price, postpaid: Pkt., 5c; 6-oz carton, $15 \mathrm{c}$; lb., $35 \mathrm{c}$. Not prepaid

THOMAS LAXTON (55 days)-Height 36 inches. This fine early Pea was raised by the Thomas Laxton is only a few days behind the Alaska, but the pods are very much larger containing on the average seven or richest flavor. It is of hardier constitution pod. In flavor this Pea is unsurpassed.

Price, postpaid: Pkt., 5c; 6-oz. carton, $15 \mathrm{c} ; 1 \mathrm{~b} . \$ 35 \mathrm{c}$. Not prepaid: 3 lbs., $75 \mathrm{c}$;
10 lbs., $22.25: 25$ lbs. $\$ 5.00$. Price, postpaid: Pkt., 5c; 7-oz. carton,
15c: lb., 30c. Not prepaid: 3 lbs., 70c; 10 lbs., $\$ 2.15 ; 25$ lbs., $\$ 4.75$.

CHAMPION OF ENGLAND (70 days)4 to 5 feet in height. This has been considered for a long time the standard main crop or late Pea for summer use. From this rariety has sprung the whole race of green wrinkled Peas. The vines are very vigorous and productive, bearing an abundance of
large, well-filled pods. The Peas are light green, wrinkled, of fine quality and delicious flavor. Hardly any Pea is sweeter than this. Price, postpaid: Pkt., 5c; 6-oz. carton, 10 lbs., $\$ 2.25 ; 25$ lbs., $\$ 5.00$.

TELEPHONE (68 days)-Height 48 inches This has become the leading pea with market gardeners whose trade appreciates fine appearance and high quality. The vines are colored leaves and producing an abundance of pointed pods of largest size, often four and one-half to five inches long, attractive bright green filled with very large peas which are tender, sweet and of excellent flavor.

Price, postpaid: Pkt., 5c; $6-\mathrm{oz}$. carton,
5c: lb., 35c. Not prepaid: 3 lbs., $75 \mathrm{c}$ $15 \mathrm{c}:$ lb., $35 \mathrm{c}$ Not prepaid: 3 lbs., $75 \mathrm{c}$;
10 lbs., $\$ 2.25 ; 25$ lbs., $\$ 5.00$.

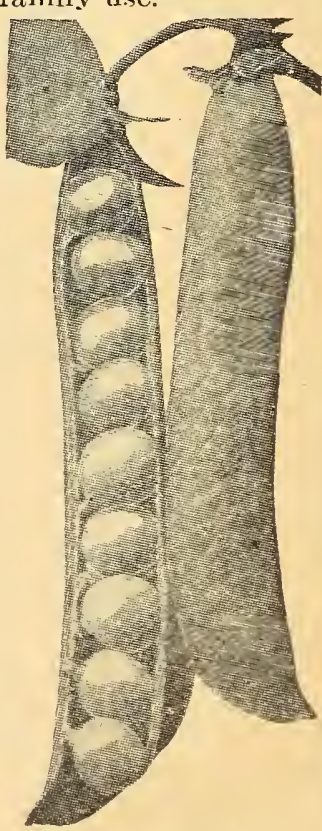

Champion of Eng. 


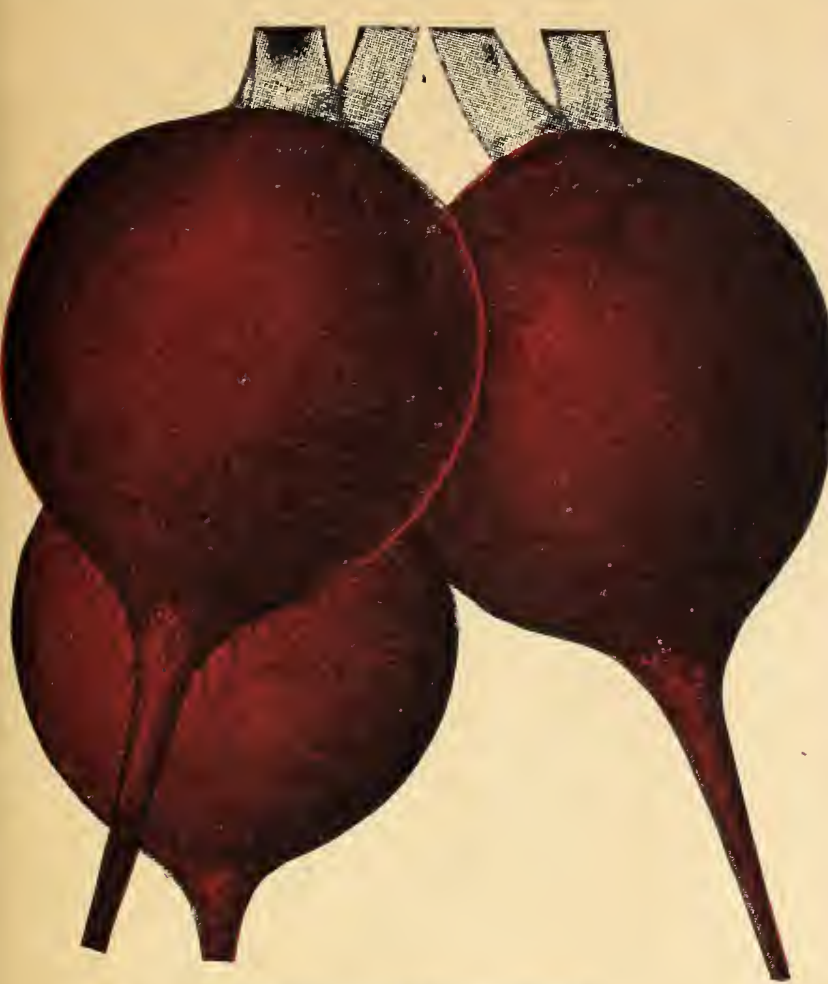

Crimson Giant Radishes

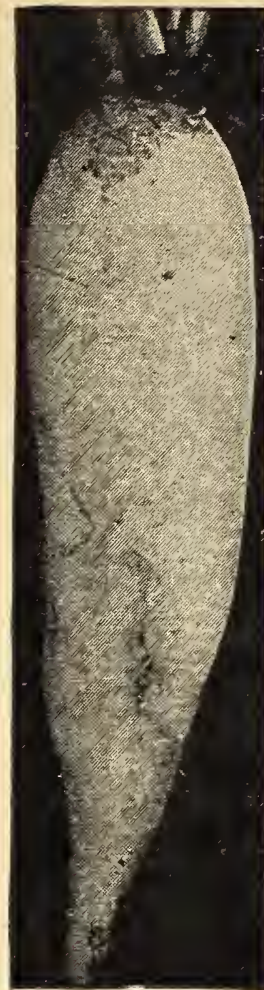

White Icicle Radish

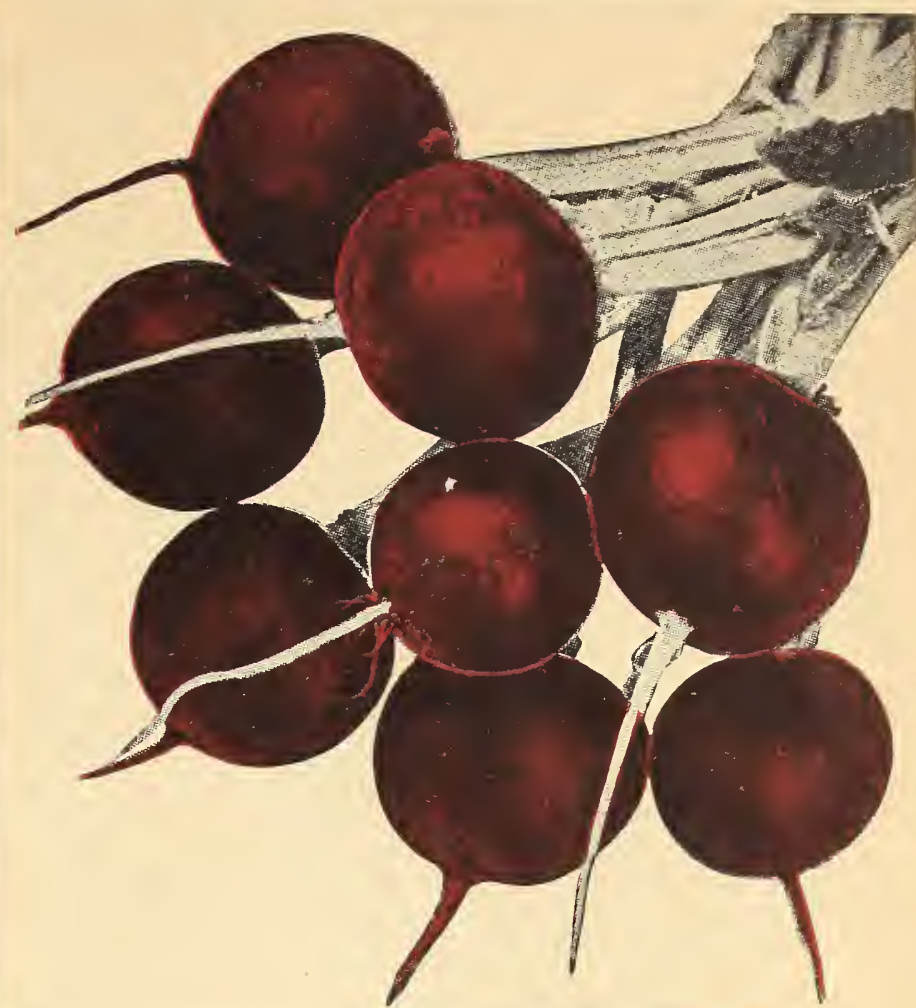

Improved Early Scarlet Globe Radishes

\section{QUALITY RADISH SEED}

(One ounce for 100 feet of drill.)

There are two kinds of Radish seed. One will produce good, crisp roots; the other will run to tops. Our seed is grown in Michigan from special French-grown planting stocks. It is carefully selected for its root-forming quality and is absolutely the best that money can buy.

PERFECTION WHITE TIP (18 days)The best strain of Scarlet Turnip White Tip Radish, with the white tip well developed, covering the lower half of the radish. Extra early, crisp and tender. This radish is a real table dainty, being very crisp and sweet. It combines beautiful appearance with finest quality, appealing at once to the eye as well leading market sort, many growers planting several hundred pounds of seed each season. Price, postpaid: Pkt., 5c; oz., 10c; $1 / 4$ lb., 30c. Not prepaid: Lb., 80c; 3 lbs., $\$ 2.25$; 5 lbs., $\$ 3.50$.

IMPROVED EARLY SCARLET GLOBE (20 days)-For forcing and for garden culture. This radish has a remarkable ability to bear the heat necessary for rapid growth without becoming pithy or losing flavor. It is very early and of surpassing beauty as regards shape and color. The flesh is crisp, tender, juicy and mild. The color is a rich scarlet. Has a small top and the radishes are surprisingly uniform in shape and size. We offer only the most carefully

Price, postpaid: Pkt., 5c; oz., 15c; 1/4 lb., 40c. Not prepaid: Lb., 90c; 3 lbs., $\$ 2.50$ 5 Ibs., $\$ 4.00$.

CRIMSON GIANT (30 days)-This is a new early radish, double the size of any of the early turnip-shaped type, and equally the early turnip-shaped type, and equally of doors. It is a rapid growing sort, developing roots of a beautiful deep crimson color ing roots of a beautiful deep crimson color, which vary in shape from round to almost oval, and often measure six inches in circumference. The flesh is the purest white, mild in flavor, firm and crisp, remaining in edible condition longer than other early sorts. We recommend this radish very highly.

Price, postpaid: Pkt., 5c; oz., 15c; $1 / 4$ lb. 45c. Not prepaid: Lb., $\$ 1.00 ; 3$ lbs., $\$ 2.85$; 5 lbs., $\$ 4.50$.

FRENCH BREAKFAST (22 days)-An old favorite for market and home garden; jus right for a small, crisp table radish. Of quick growth, oblong in shape; color a beautiful scarlet, except near the tip where it is pure white. A splendid variety on account of its excellent quality and attractive color. Price, postpaid: Pkt., 5c; oz., 10c; $1 / 4 \mathrm{lb}$ 5 lbs., $\$ 3.50$

WHITE BUSH SCALLOP (50 days)(Patty Pan.) Matures early and will bear throughout the season if fruits are kept gathered. Squashes are clear white and of large size. Flesh is thick and of very fine quality. Price, postpaid: Pkt., 5c; oz., 15c; 1/4 lb., $40 \mathrm{c} ; 1 \mathrm{~b} ., \$ 1.25$.

GOLDEN HUBBARD (70 days)-The best winter Squash for the private or home garden and desirable for market; the fruits are of the and desirable for market; the fruits are of the same shape as Green Hubbard, and warted,
but average smaller in size. They are earlier but average smaller in size. They are earlier in season but keep in fine condition through the winter. The skin is bright deep orange
yellow, very attractive in appearance. Flesh yellow, very attractive in appearance. Flesh
is deep golden yellow, fine-grained, cooks very dry and has rich flavor. Yields extra heavy, even on lighter soils.

Price, postpaid: Pkt., 5c; oz., 15c; 1/4 lb., $45 \mathrm{c}$; lb., $\$ 1.35$. Not prepaid: 3 lbs., $\$ 3.25$; 5 lbs., $\$ 5.00$

TRUE HUBBARD (75 days)-One of the best of the winter squashes. The vines are
vigorous and very productive. The fruits vigorous and very productive. The fruits a very hard shell. The skin is uniformly dark bronze green. The flesh is bright orange-yellow, fine-grained, thick, dry and
1 CI CLE ( 30 days)-A beautiful, waxy-white long-rooted Radish, gradually tapering down from the shoulder which is about $1 / 2-i n c h$ small tops. This is the earliest of the longrooted early summer white sorts and is very desirable for outdoor planting, and also good for forcing. Flesh is crisp and tender.

Price, postpaid: Pkt., 5c: oz., 10c; $1 / 4 \mathrm{lb}$. 30c. Not prepaid: Lb., 80c; 3 lbs., $\$ 2.25$ 5 lbs., $\$ 3.50$.

LONG SCARLET SHORT TOP (35 days) -The old standard early long variety for market and home garden. Roots long, growing partly above ground, straight, smooth, rich scarlet color, very crisp and quick grower; grows to six inches in length and can be used long before it is fully grown.

Price, postpaid: Pkt., 5c; oz., 10c; $1 / 4$ lb. 30c. Not prepaid: Lb., 80c; 3 lbs., $\$ 2.25$ 5 lbs., $\$ 3.50$.

MIXED RADISHES-Radishes of all colors -red, pink and white, round, oblong, halflong and long; and from the earliest to the very latest varieties. Just what is wanted for the home garden where the space is limited. One sowing is all that is required Price, postpaid: Pkt., 5c; oz.., 10c; 1/4 lb. $25 \mathrm{c} ; 1 \mathrm{~b}, 65 \mathrm{c}$.

richly flavored. This squash can be kept in good condition until spring. Our stock of this standard home garden and market variety is carefully selected in regard to quality of the flesh and color of the shell and is much superior to that sold as Chicago Warted or Warty Hubbard.

Price, postpaid: Pkt., 5c; oz., 15c; 1/4 lb., $45 \mathrm{c} ;$ lb., $\$ 1.50$. Not prepaid: 3 lbs., $\$ 3.65$; 5 lbs., $\$ 5.50$

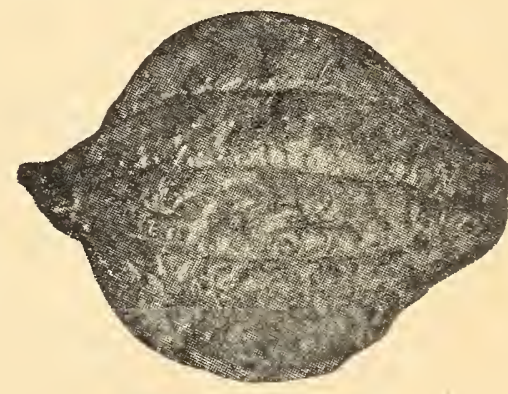

Hubbard Squash 


\section{TOMATOES}

( $1 \mathrm{oz}$. of seed will produce 3,000 to 4,500 plants).

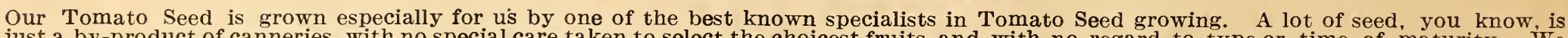

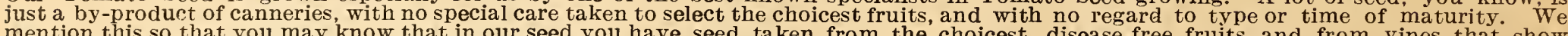

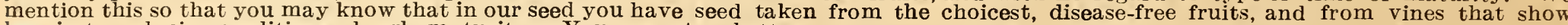
heaviest producing qualities and early maturity. You can get no better.

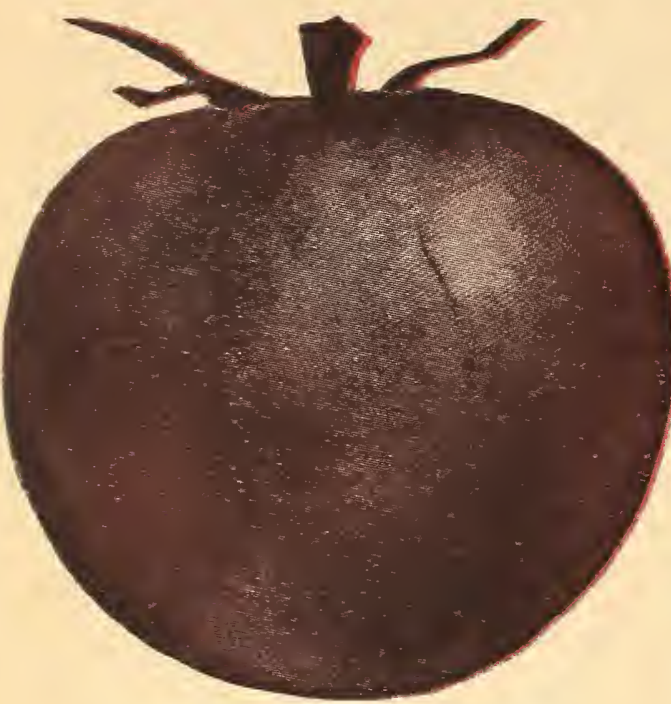

The Famous Magi-Queen

\section{THE FAMOUS MAGI-QUEEN}

\section{(85 days).}

Since its introduction in 1912 by our $\mathrm{Mr}$. Mackey, then with the Ratekin Seed House, Shenandoah, Iowa, this wonderful Tomato has displaced all others of its class in popularity.

Magi-Queen is earlier than any other sort, without exception. In comparative tests
with the well known Earliana, seeds sown at whe same time and the plants set out at the same time, The Magi-Queen gave ripe fruits 5 days sooner. Magi-Queen is surprisingly productive. We have seen clusters containing 20 full sized fruits.

Magi-Queen is perfectly smooth from beginning to end of season. No variety is more uniform in shape, all the tomatoes on a cluster ripen at once and are all about the same size. Its color is a beautiful deep glossy scarlet, and very attractive.

The table quality is surpassed only by the large beefsteak sorts, and it has fewer seeds than any of the other early sorts. Its flavor is all that can be desired.

Price, postpaid: Pkt., 10c; $1 / 2$ oz., 30c: $1 \mathrm{oz} ., 50 \mathrm{c} ; 1 / 4 \mathrm{lb} ., \$ 1.50$.

\section{THE "NO NAME" WONDER TOMATO}

The Tomato shown on the back cover page. We don't want to tell you too much about it as we want you to grow jt and then give us your unbiased opinion of its merits. We want you to name it, too. We want a good wame and as an inducement for you to give name and as an inducement for you to give the name, we offer a prize of $\$ 15.00$ cash for the name, we offer a prize of $\$ 15.00$ cash for the best name submitted and another prize of $\$ 10.00$ for the best letter regarding the Tomatoes you grow from the seed of this wonderful new variety. Read full partic. ulars of this offer on the back cover page, then send us 25c for your packet of seed. We didn't get much seed from our crop this year so can only allow one packet to a neighbor be sure to give their names, otherwise we can send you but one packet.

se we can send you but one packe, postpaid: Packet, 25c.
Price

EARLIANA (90 days)-Our strain of this popular variety shows few, if any, of the rough fruits found in numerous quantities in other early sorts. Plants are of compact growth with stout-jointed branches. Yields well and the fruit is solid and of fine quality; bright red in color, of good size.

Price, postpaid: Pkt., 5c; oz., 25c; 1/4 lb.

\section{IMPROVED DWARF CHAMPION (105} days)-This popular dwarf tomato probably combines more good qualities than any other upright variety. Dwarf in habit making compact, stiff, upright plants, which carry the fruit well above the ground fruit medium lore color fruit medium large, color purplish-pink, and set as close as 30 inches apart. Specially set as close as 30 inches apart. Specially Price, postpaid: Pkt., 5c; $1 / 2$ oz., 25c; oz., 40c; $1 / 4$ lb., $\$ 1.25$.

NEW STONE (115 days)-The most popular main crop tomato and there is probably more seed sold of this sort than all others combined. It has obined immense market obardeners, and home growers everywhere. Its solidity and carrying qualities are remarkable. Its and carrying qualities are remarkable. Its color is a desirable red. Its shape is per-
fectly smooth.

$75 \mathrm{c}$.

IMPROVED PONDEROSA (120 days.Quite smooth, of immense size, very meaty, solid and luscious. For family gardens it is deserving of universal use and many market

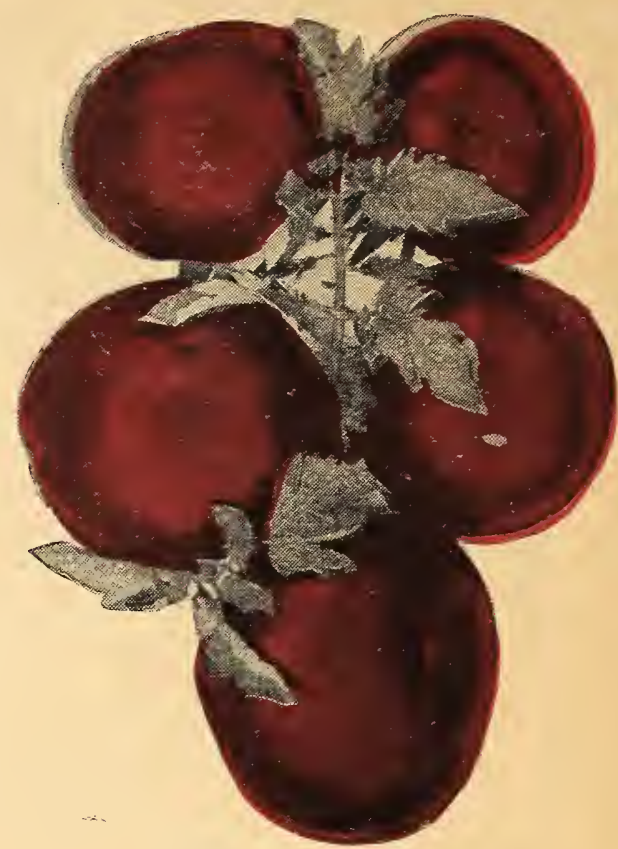

Ponderosa Tomato

gardeners plant Ponderosa every year for their special trade. Unsurpassed in size and of fine quality for slicing. The vines are of strong growth and produce large clusters of beautiful tomatoes, they are extremely prolific and bear continously until frost The extra large, deep purple fruits are oblong

Price, postpaid: Pkt, 5c; $1 / 2$ oz., 30; oz. 50c; $1 / 4$ ' lb., $\$ 1.50$.

GOLDEN QUEEN (105 days)-Handsome fruit of good size and very smooth, solid and meaty, mild in flavor. Color is a bright yellow, making a decidedly attractive dish when served together with red fruited tomatoes.

served together with red fruited tomatoes.
Price, postpaid Pkt., 5c; $1 / 2$ oz., 30c; oz., P0c; $1 / 1$, lb. $\$ 1.50$.

PEAR-SHAPED YELLOW.-Bright yellow. Fruit small, pear-shaped, about size of plum. Ripens early. Used for pickling and preserving. $50 \mathrm{c}$.

\section{TURNIP}

$3 / 4$ oz to $1 \mathrm{CO}$ feet of drill. 1 to $2 \mathrm{lbs}$. per acre).

EARLY WHITE FLAT DUTCH (50 days) - A very popular sort for table or market: -A very popular sort for table or market; grows quickly, comes early ; clear white skin, bulbs free from small roots.

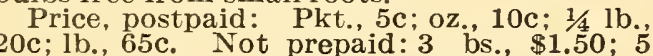
lbs., $\$ 2.25$.

WHITE EGG (55 days)-A quick grower; a rand, good keeper; excellent either as an early or late variety. The flesh is very sweet, firm and mild, never having the rank, strong taste of some varieties.

Price, postpaid: Pkt., 5c; oz., 10c; 1/4 1b., $25 \mathrm{c}$; lb., 80c. Not prepaid: 3 lbs., $\$ 2.00$;

PURPLE TOP, STRAP-LEAVED (60 days - The most popular sort. A general favorite with all, and more largely grown than any cast or in drili, will do well to sow either broadin seven or eight weeks. Rathe: flat and of

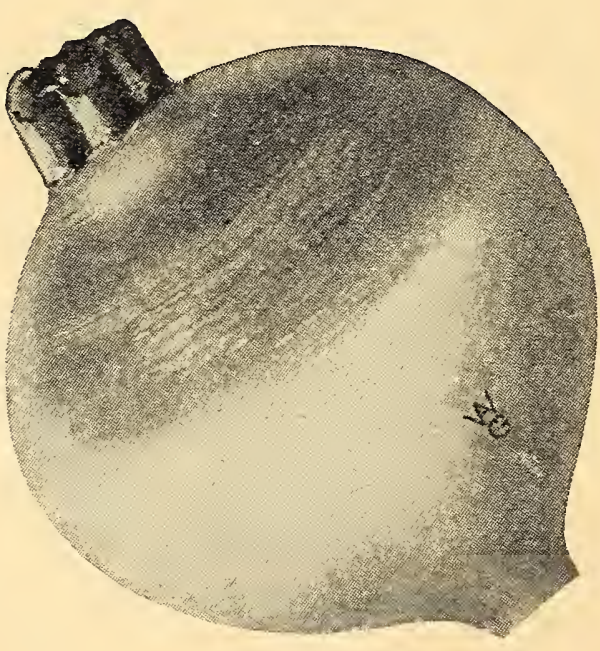

Purple Top White Globe medium size. Color, purple above ground white below; flesh, white, fine grained and tender.

Price, postpaid: Pkt., 5c; oz., 10c; $1 / 4$ lb. 20c; lb, 65c. Not prepaid: 3 lbs., $\$ 1.50$ $5 \mathrm{lbs}, \$ 2.25$

PURPLE TOP WHITE GLOBE (65 days)Of a perfect globe shape, about six inches in diameter, with smooth, white skin; flesh pure white, firm and crisp, and of quick growth. A good keeper and is fine for market.

Price, postpaid: Pkt., 5c; oz., 10c; 1/ lb. 20c: lb. 65c. Not prepaid: 3 lbs., $\$ 1.50$ 5 lbs., $\$ 2.25$.

\section{RUTABAGA}

AMERICAN PURPLE TOP ( 80 days)This train is of American origin and is a purple top, yellow variety. It has been selected to produce a smaller top and a shorter neck than is usually found; the roots grow to a large size and are of the finest quality and excellent both for the table and for stock feeding.

Price, postpaid: Pkt.; 5c; oz., 15c; $1 / 4 \mathrm{lb}$. 35 ; lb.. 90c. Not prepaid: 3 Ibs., \$2.25; 5 lbs., $\$ 3.50$ 


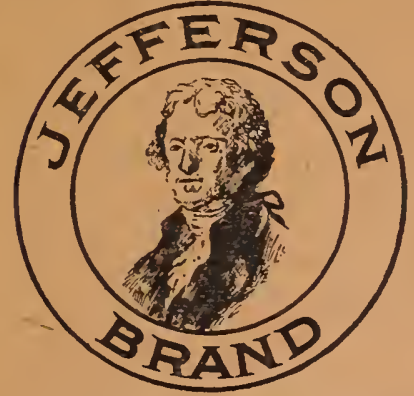

\section{Order Sheet For}

\section{JEFFERSON BRAND SEEDS}

le fall. to $21 / 2$

\section{"Always Dependable"}

\section{JEFFERSON SEED HOUSES - JEFFERSON, IOWA}

When it is considered how many are the contingencies upon which the success of any crop depends, we cannot guarantee the crop, and therefore Jefferson Seed Houses give no warranty, express or implied, as to description, quality, productiveness, or any other matter, of any seeds, bulbs or plants they send out, and they will not be in any way responsible for the crop. If the purchaser does not accept the goods on these terms they are at once to be returned.

Jefierson Seed Houses.

Date

19........ Send by

(State Freight, Express or Mail)

Your Name

Postoffice

County

State

Street and No.

P. O. Box No.

Name of town to which you wish

freight or express shipments made $\}$

Is there a Freight Agent at your shipping point?...........Name of R. R. Co.

(If there is no agent, send extra money to pay freight)
AMOUNT ENCLOSED

Money Order \$

Draft. . . . . . \$

Check. . . . . . \$ .

Cash........ $\$$

Stamps....... \&

Total.....\$
MIX

ve are

ties in

ations,

s well.

give a

Plen.

MIX-

flower-

as and

grown

rselves

c; oz.

d-fash

easy

ler and

hen in

igorous

plants

SRING

als of

rpet of

gin to

gin to

IIAS-

al use;

over 3

ng 5 to

ture of

perfect

$t$ been

merica.

ase all

OWER

OWER

almost

rer and

rroduce

is seed

an un-

an un-

ing, as

oo their

es new

- extra

$25 \mathrm{c}$ 
January 1, 1924.

Our Tor just a by meaviest
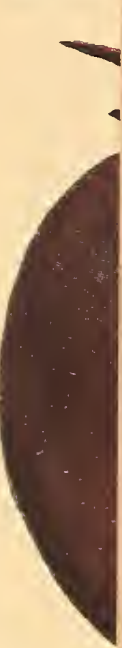

TH]

Since it Mackey Shenand has disp Magi-Q1 without with the the sam same tir 5 days product Magi-Q Magi-Q ginning more un cluster same si glossy s large be than an is all th Price, $1 \mathrm{oz} ., 5 \mathrm{C}$

\section{Jefferson Brand Seed Corn:}

\section{Jefferson Brand Clovers and Alfalfa.}

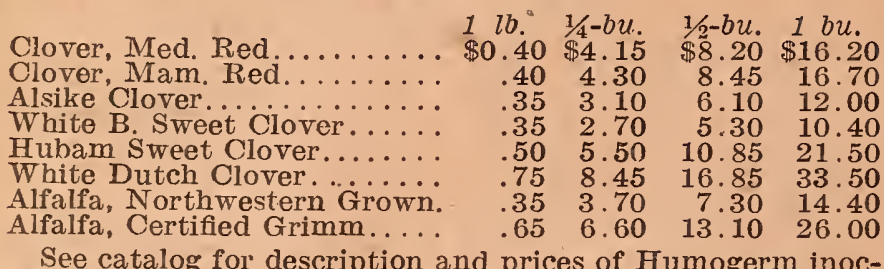
ulation.

\section{Timothy and Mixed Seeds.}

Timothy, New Crop. Iowa Timothy and Alsike Mixed.. (20\% Alsike-50 lbs. per bu.) Permanent Pasture Mixture.
Towa Lawn Grass..........

\section{Light Grasses.}

Kentucky Blue Grass. Meadow Fescue.

Rye Grasses......

Orchard Grass...
Red Top.......
Bromus Inermus.

Forage and Fodder Crops.

Sudan Grass.

Billion Dollar Grass

Dwarf Essex Rape........

Cane, Amber Fodder.

Cane, Genuine Sorghum

Kaffir Corn

Sand or Winter Vetch.

Soy Beans, Manchu.

Soy Beans, Black Eyebrow.

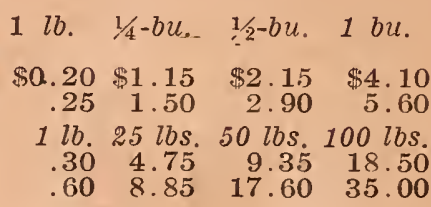

$1 \mathrm{lb}, 25 \mathrm{lbs} .50 \mathrm{lbs}, 100 \mathrm{lbs}$ $\$ 0.50 \quad \$ 7.50 \quad \$ 14.85 \$ 29.50$ $\begin{array}{rrrr}.30 & 3.85 & 7.60 & 15.00 \\ .30 & 3.85 & 7.60 & 15.00\end{array}$ $\begin{array}{rrrr}.30 & 3.85 & 7.60 & 15.00 \\ 35 & 5.35 & 10.60 & 21.00\end{array}$ $\begin{array}{rrrr}.35 & 4.70 & 9.35 & 18.50 \\ .30 & 3.85 & 7.60 & 15.00\end{array}$

\begin{tabular}{rrrr}
1 & $l b$. & $25 l b s$. & \multicolumn{3}{c}{$50 l b s}$. & $100 l b s$. \\
$\$ 0.25$ & $\$ 2.60$ & $\$ 5.10$ & $\$ 10.00$ \\
.20 & 1.35 & 2.60 & 5.00 \\
.25 & 2.35 & 4.60 & 9.00 \\
.20 & 1.10 & .2 .10 & 4.00 \\
.20 & .85 & 1.60 & 3.00 \\
.20 & 1.00 & 1.85 & 3.50 \\
.20 & 1.00 & 1.85 & 3.50 \\
.30 & 3.85 & 7.60 & 15.00 \\
.20 & 1.65 & 3.20 & 6.25 \\
.20 & 1.60 & 3.10 & 6.00
\end{tabular}

See catalog for description of varieties and our methods of handling dependable Seed Corn.

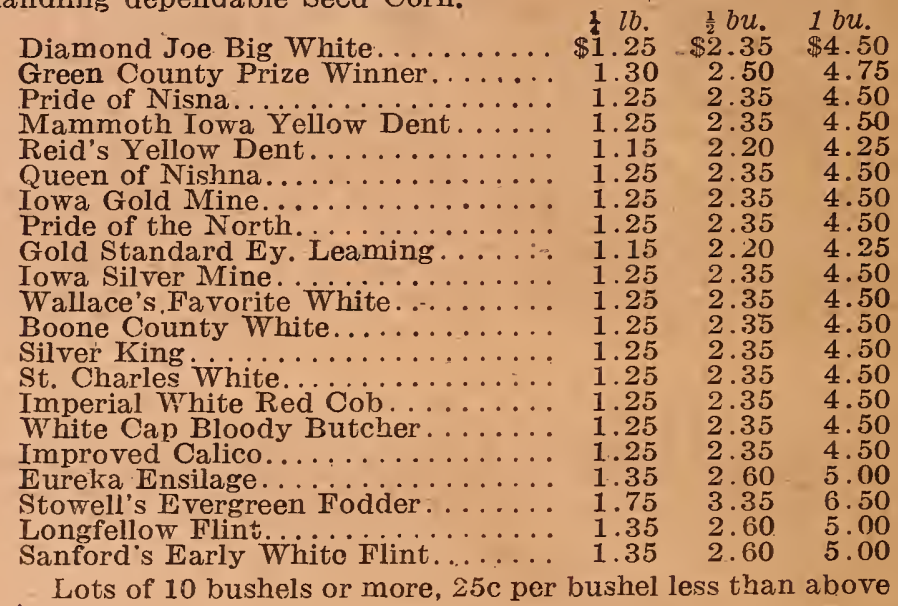
prices.

\section{Seed Grain.}

Pedigreed strains grown on our own farms and carefully recleaned. $1 \mathrm{lb} .1 \mathrm{bu} .5 \mathrm{bu} . \quad 10 \mathrm{bu}$.

SEED OATS, lowa $103 \ldots \ldots \quad \$ 0.20 \$ 1.10 \quad \$ 1.05 \quad \$ 1.00$

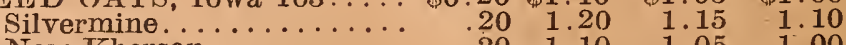

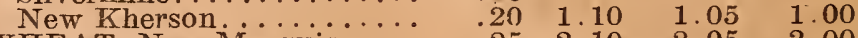
WHEAT, New Marquis. . . $\quad .25 \quad 2.10 \quad 2.05 \quad 2.00$

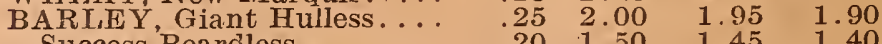

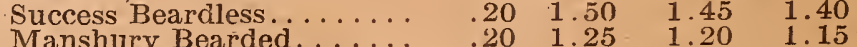

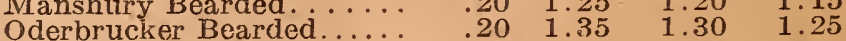
$\begin{array}{lllll}R Y E, \text { Mammoth Spring } . . . & .25 & 2.10 & 2.05 & 2.00\end{array}$ BUCKWHEAT, Japanese... $\quad .25 \quad 2.30 \quad 2.25 \quad 2.20$

We'll gladly send sample; of any of the above seeds in which you may be interested. All seeds are sold under our rigid "satisfaction or money back" guarantee. Every bag is tagged showing purity and germination.

In addition to Field and Grass Seeds we grow and handle the highest quality Vegetable-and Flower Seeds. See catalog for descriptions and prices.

\section{JEFFERSON SEED HOUSES JEFFERSON, IOWA}

"Iowa's Live Seed'Growers and Dealers" 


\section{POPULAR FLOWER SEED}

Price, postpaid: All Flower Seed, except where noted, extra large plts., 10c; 3 pkts. same variety, 25c.

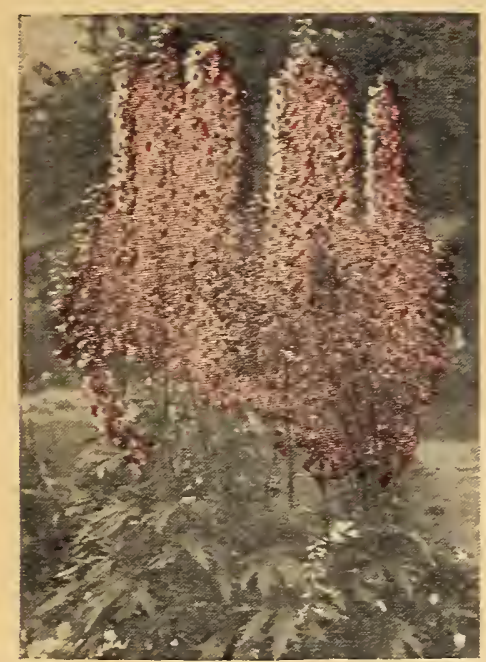

Larkspur green follage; at the approach of autumn the foliage turns to a deep red color. Height. 2 to 3 feet

LARKSP UR - Well-known annuals of great beauty and noted for the richness of their colors

MARVEL OF PERU-(Four-o'Clock). Bushy plants of easy culture, producing hundreds of flowers diring the entire sum-

MARIGOLDS-AFRICAN AND FRENCH MIXED-These are old favorite free-flowertremely effective and are well adapted for large beds or mixed borders: they succee best in a light soil. With full exposure to the sun. A rase or bowl of any of the rich yel Larkspurs or Corn-flowers is rert striking.

MIGNONETTE, Sweet-scented-Taluable on account of its fragrance; sow in suc-

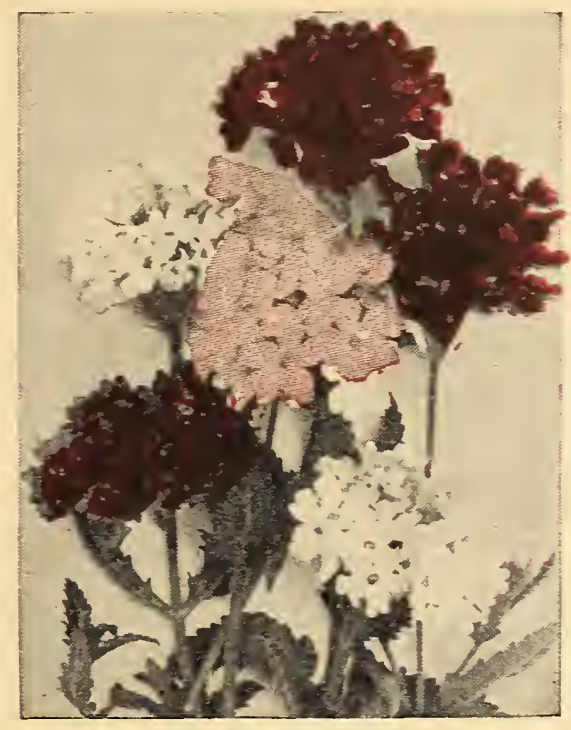

Verbenas

ASTERS-QUEEN OF THE MARKETThe best of the extra-early varieties, fully quite large and double. Mixed colors.

ASTERS-AMERICAN BRANCHINGThe best all around Aster. In their full glory in September. The flowers are big balls of color often 4 inches across, always on
long stems, fine for cutting. Mixed colors.

ALYSSUM, LITTLE GEM. A.-Dwarf spreading plants about four inches high and covered with a mass of white bloom.

BACHELOR'S BUTTON (Ragged Robin, Cornflower, or Blue Bottle.) - One of the most popular and desirable of old-fashioned garden annuals. Bachelor's Button and Baby's Breath make a most beautiful bouquet. Hixed colors, double and single.

BABY'S BREATH (Gypsophila).-Tery easily grown annuals, 12 to 15 inches high. The flowers are pure white, very small, star-
like, and produced in feathery sprays. Always useful for combining with other flowers in bouquets or small rases for table decoration.

CALENDULA (Scotch Marigold)-One of the best and shomiest free-flower ng hardy annuals, growing in any good garden soil producing a fine effect, in beds or mixed borders; particularly bright in late fall, confrost; valuable also for pot culture, blooming in winter and spring. Richest yellow and orange.

COSMOS-EARLY LARGE FLOWERING-The most desirable type to plant in ING-The most desirable type to plant in continuing until killed by frost. The flowers are large, in delicate shades of pink deep rose and white. Cosmos is one of the best tal (4-6 ft.) border plants, and you can pick great armsful of flowers.

COCKSCOMB-Showy dwarf growing plants bearing large relvety combs. If the and used for winter decorations.

CYPRESS VINE-A very graceful annual climber, with feathery foliage and beautiful star-like flowers. Mixed colors.

DIANTHUS, OR PINKS A most satisfactory class of flowers, easily raised from seed, and which are in constant bloom the entire season; fragrant.

EVERLASTING MIXTURE for Winter Bouquets-The Everlastings or Straw Flowers are very desirable for winter bouquets and other decoration during the winter months when flowers are scarce.

HOLLYHOCK-One of the most popular and desirable of hardy perennial plants excellent for planting among shrubbery o Height, 6 to 7 feet. KOCHIA (Summer Cypress, or Mexican Firebush)-An easily grown annual which grows into a cypress-like hedge, with feathery make a veritable blaze of color in the fall Sow the seed in the house early or out-doors about May first. Height about 2 to $21 / 2$ feet.

SWEET PEAS-GIANT SPENCER MIXTURE-In preparing this mitture we are giving our customers all the best rarieties in this class and all possible color variations, including many brand new kinds as Tell. most magnificent display of the Giant Spencer types. Satisfaction guaranteed. Pkt.

SWEET PEAS-GRANDIFLORA MIX. TURE-A special blend of the large flower ing or Grandiflora class of weet Peas and as a mixture but is "blended" br ourselves and consists of the largest flowering, most SWEET WILLIAM- Tell-known, old-fash ioned, hardy perennials of Tery easy ioned, hardy perennials of Tery easy for massing. A gorgeous display when in bloom, comprising many brilliant colors. It plants each rear, and destroy the old plants VERBENAS-MAMMOTH FLOWERING MIXEDlow spreading growth, forming a carpet of bright colors when in bloom. Begin to frost.

GIANT FLOWERING ZINNIASforming bu the compact plant general use feet high and bearing flowers measuring 5 to 6 inches across. In this special mixture of Double Zinnias are found the most perfect and beautiful types which have ret been produced by the flower specialists of America. Who grow them

HAPHAZARD MIXTURE OF FLOWER SEED-GRAND FOR WILD FLOWER GARDENS-This mixture contains almost is useful as an inexpensive way to produce displars on large borders or to sow hillsides or along lanes or walks. By using this seed liberally it is easy to convert many an un-
sightly spot into a bower of beauty. For the children nothing is so interesting, as they can pick flowers and bouquets to their heart's content. Every day furnishes new surprises.

Price, postpaid: All Flower Seed, extra large pkts., 10c; 3 pkts. same variety, $25 \mathrm{c}$.

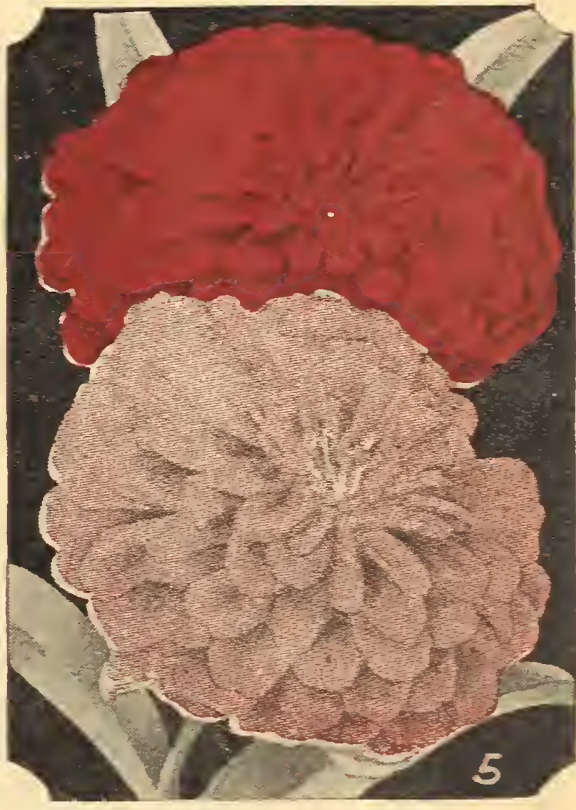

Zinnlas 



\section{IA New "Wonder" Tomato}

CFTER eleven years of search and selection we are ready to introduce a Tomato that even surpasses the now famous Magi-Queen, introduced in 1912 by our Mr. Mackey, then with the Ratekin Seed House, Shenandoah, Iowa. This new Tomato is positively the largest, most handsome, and finest flavored of any in the second-early class; it's one that will meet with instant favor with every lover of the tomato, and easily takes first place. in the home and market garden.

\$15.00 CASH FOR SUITABLE NAME.

Unable to agree upon a name that will do this "Wonder" Tomato iustice, we have decided to let cur customers choose one. The name must be worthy of the Tomato, preferably one that is suggestive of its great merits. For rizes. Our supply of the "No Name" Tomato is all packed in sealed packets and will be mailed, one to a tomer, for 25c per pkt. 